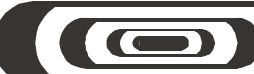 \\ oen
}

AUTARQUIA ASSOCIADA À UNIVERSIDADE DE SÃO PAULO

RENATURAÇÃO DAS PROTEÍNAS NÃO ESTRUTURAIS 1 (NS1) DOS VÍRUS DA ZIKA E DA DENGUE UTILIZANDO ALTAS PRESSÕES

CLEIDE MARA ROSA DA SILVA

Dissertação apresentada como parte dos requisitos para obtenção do Grau de Mestre em Ciências na Área de Tecnologia Nuclear - Aplicações

Orientadora:

Profa. Dra. Ligia Ely Morganti Ferreira Dias 
INSTITUTO DE PESQUISAS ENEGÉTICAS E NUCLEARES

Autarquia Associada à Universidade de São Paulo

\section{RENATURAÇÃO DAS PROTEÍNAS NÃO ESTRUTURAIS 1 (NS1) DOS VÍRUS DA ZIKA E DA DENGUE UTILIZANDO ALTAS PRESSÕES}

CLEIDE MARA ROSA DA SILVA

Dissertação apresentada como parte dos requisitos para obtenção do Grau de Mestre em Ciências na Área de Tecnologia Nuclear - Aplicações

Orientadora:

Profa. Dra. Ligia Ely Morganti Ferreira Dias

Versão Corrigida

Versão Original disponível no IPEN 
Auxílio FAPESP: processo n. 02574-0

Autorizo a reprodução e divulgação total ou parcial deste trabalho, para fins de estudo e pesquisa, desde que citada a fonte.

Como citar:

SILVA, C.M.R. Renaturação das proteínas não estruturais 1 (NS1) dos vírus da zika e da dengue utilizando altas pressões. 2017. 77 p. Dissertação (Mestrado em Tecnologia Nuclear) Instituto de Pesquisas Energéticas e Nucleares - IPEN-CNEN/SP. São Paulo. Disponível em: <http://www.teses.usp.br>. Acesso em: dd/mm/aaaa.

Ficha catalográfica:

Silva, Cleide Mara Rosa da

Renaturação das proteínas não estruturais 1 (NS1) dos vírus da zika e da dengue utilizando altas pressões

Cleide Mara Rosa da Silva. Orientadora Ligia Ely Morganti Ferreira Dias.

São Paulo, 2017.

$77 \mathrm{p}$.

Dissertação ( Mestrado) - Programa de Pós-graduação em Tecnologia Nuclear.

Área de concentração ( Aplicações) -- Instituto de Pesquisas Energéticas e Nucleares. Universidade de São Paulo.

1. Renaturação. 2. Reenovelamento. 3. Redobramento. 4. Proteínas. 5. Corpúsculos de inclusão. 6. NS1. 7. Vírus da dengue. 8. Vírus da zika. 9. Alta pressão hidrostática. 


\section{FOLHA DE APROVAÇÃO}

Autor: Cleide Mara Rosa Da Silva

Título: Renaturação das proteínas não estruturais 1 (NS1) dos vírus da zika e da dengue utilizando altas pressões

Orientadora: Ligia Ely Morganti Ferreira Dias

Dissertação apresentada ao programa de Pós-Graduação em Tecnologia Nuclear da Universidade de São Paulo para a obtenção do título de Mestre em Ciências.

Data $11 / 08 / 2017$

\section{Banca Examinadora}

Prof. Dr.:

Instituição: Julgamento:

Prof. Dr.: Instituição: Julgamento:

Prof. Dr.: Instituição: Julgamento:

Prof. Dr.: Instituição: Julgamento:

Prof. Dr.: Instituição: Julgamento: 


\section{AGRADECIMENTOS}

A minha orientadora, Dra Ligia Ely Morganti Ferreira Dias, pela oportunidade, pela confiança, por toda orientação e apoio. Agradeço a compreensão, a benevolência, a generosidade, a motivação, enfim, foram tantas coisas que escreveria infinitamente.

Agradeço também ao Instituto de Pesquisas Energéticas e Nucleares (IPEN), à FAPESP (Projeto de Auxilio à Pesquisa 2015/ Processo: 02574-0) e ao CNPq pela bolsa de mestrado (Processo: 130256/2015-3) que tornaram a realização deste trabalho possível.

Agradeço aos colegas de laboratório que compartilharam conhecimentos e aflições, especialmente a Rosa Churra-Chambi, que mostrou-se uma ótima professora, expressando conhecimento, sabedoria e paciência, sempre tão solícita em atender-me em minhas dificuldades.

Ao Dr. Luis Carlos de Souza Ferreira e ao doutorando Lennon Ramos Pereira do Departamento de Microbiologia do ICB-USP, colaboradores sempre gentis.

Agradeço também a todos os professores que plantaram em mim a semente da confiança, em especial a Cassia Xavier, que em 2008, quando eu fazia um curso técnico, enviou um trabalho meu para o XXIV CONGRESSO INTERAMERICANO DE RADIOLOGIA, ela não sabe, mas plantou em mim a paixão pela Academia. Gratidão!

Não posso deixar de agradecer ao meu filho Enzo, pequeno anjo que torna meus dias mais doces e felizes, me dando equilíbrio para seguir me dedicando ao trabalho. A minha irmã Reginalda, que cuidou dele até tarde enquanto eu trabalhava, minha gratidão, irmã querida. E as minhas amigas Ana Paula, Cristina, Daniele e Izabel por, mesmo de longe, tornarem meus dias mais leves, compartilhando boas conversas e sorrisos. Eu as amo!

E por último, porém o mais importante, agradeço a DEUS por cada passo dado, por cada lição aprendida e por cada nova chance! 
"Cada pessoa deve trabalhar para o seu aperfeiçoamento e, ao mesmo tempo, participar da responsabilidade coletiva por toda a humanidade." 


\section{RESUMO}

SILVA, C.M.R. Renaturação das proteínas não estruturais 1 (NS1) dos vírus da zika e da dengue utilizando altas pressões. 2017. 77 p. Dissertação (Mestrado em Tecnologia Nuclear) Instituto de Pesquisas Energéticas e Nucleares, São Paulo.

As principais matérias primas necessárias para a preparação de testes diagnósticos são as proteínas dos patógenos que necessariamente apresentem as estruturas nativas. O objetivo do presente estudo foi a obtenção das proteínas não estruturais 1 (NS1) dos vírus da dengue (DENV) e da zika (ZIKV) a partir dos corpúsculos de inclusão $(\mathrm{Cl})$ produzidos em bactérias Escherichia coli. Mostramos que a combinação de alta pressão hidrostática (APH) e pH alcalino é eficiente para a solubilização de NS1-Cl. A incubação em 2,4 kbar das suspensões de NS1-Cl em pH alcalino mostrou-se eficiente para a solubilização da NS1. A presença de Arg promove a dissociação de oligômeros. A aplicação de 2,4 kbar às suspensões de NS1-Cl em pH de 10,5 (DENV) e de 11,5 (ZIKV) na presença de Arg e um par redox, seguida de diálise em tampão em $\mathrm{pH} 8,5$, foram as condições escolhidas para o reenovelamento de NS1. Obtivemos ambas NS1 com rendimentos entre $75 \%$ e $90 \%$ em relação às quantidades totais das proteínas presente nos correspondentes $\mathrm{Cl}$ de NS1. As NS1 reenoveladas apresentaram reatividade comparável às proteínas obtidas utilizando um protocolo convencional estabelecido, com rendimentos mais de 25 vezes superiores. Foi obtido um processo altamente eficiente para o reenovelamento de NS1 apresentando características biológicas preservadas em relação a reatividade com anticorpos específicos de antígeno, incluindo soro de paciente infectado com zikv e que, portanto, podem ser usados como antígeno para o desenvolvimento de vacinas ou testes de diagnóstico. Além disso, este estudo descreve a criação de um processo inovador, que é a utilização concomitante de $\mathrm{APH}$ e pH alcalino, para solubilização e posterior reenovelamento de $\mathrm{NS} 1-\mathrm{Cl}$ que podem ser utilizados para outras proteínas relevantes.

Palavras chave: Renaturação, reenovelamento, proteínas, corpúsculos de inclusão, NS1, vírus da dengue, vírus da zika e alta pressão hidrostática. 


\begin{abstract}
SILVA, C.M.R. Refolding of non-structural proteins 1 (NS1) of zika and dengue viruses using high. 2017. 77 p. Dissertation (Master in Nuclear Technology) Instituto de Pesquisas Energéticas e Nucleares, São Paulo.
\end{abstract}

The main products for the preparation of diagnostic tests are as proteins of the pathogens that necessarily present as the native structures. The objective of the present study was to obtain non-structural proteins 1 (NS1) from dengue virus (DENV) and zika virus (ZIKV) from the inclusion bodies (IBs) produced in Escherichia coli bacteria. We show that it is a combination of high hydrostatic pressure (HHP) and alkaline $\mathrm{pH}$ is efficient for a solubilization of NS1-IB. A 2.4 kbar incubation of NS1-IB suspensions at alkaline $\mathrm{pH}$ proved to be efficient for NS1 solubilization. The presence of Arg promotes the dissociation of oligomers. The application of $2.4 \mathrm{kbar}$ to the suspensions of NS1-IB at pH 10.5 (DENV) and $11.5(\mathrm{ZIKV})$ in the presence of Arg and a redox pair, dialysis in $\mathrm{pH} 8.5$ buffer were as conditions chosen for the refolding of NS1. We obtained both NS1 at yields between $75 \%$ and $90 \%$ relative to the total amounts of the proteins present in the corresponding NS1 IB. Refolded NS1 showed similar to proteins obtained using an established standard protocol, with yields more than 25 times higher. A highly efficient process for the refolding of NS1 was obtained with preserved biological features regarding reactivity with antigen-specific antibodies, including sera of zikv-infected patients and that can be used as antigen for the development of vaccines or diagnostic tests. In addition, this study describes the creation of an innovative process, which is a concomitant use of $\mathrm{HHP}$ and alkaline $\mathrm{pH}$, for solubilization and subsequent refolding of NS1-IB that can be used for other relevant proteins.

Key words: Renaturation, refolding, proteins, inclusion bodies, NS1, dengue virus, zika virus and high hydrostatic pressure. 


\section{LISTA DE TABELAS}

TABELA 1. Quantificação de NS1 DENV de amostras reenoveladas pela aplicação de pressão (2,4 kbar por 90 min e 0,4 kbar por 6h30min) por A280 $\mathrm{nm} \ldots 50$

TABELA 2. Quantificação de NS1 DENV de amostras reenoveladas pela aplicação de pressão (2,4 kbar por 90 min e 0,4 kbar por 6 h30min) por A280 n......51

TABELA 3. Quantificação de NS1 ZIKV de amostras reenoveladas pela aplicação de pressão (2,4 kbar por 90 min e 0,4 kbar por 6h30min) por A280 nm...................68 


\section{LISTA DE FIGURAS}

Figura 1. Estrutura do dímero de NS1 do vírus do oeste do Nilo .21

Figura 2. Bomba e vaso de alta pressão (High Pressure Equipment). .27

Figura 3. Efeitos da alta pressão sobre a solubilização da NS1 DENV. Gráficos de Espalhamento de Luz. 30

Figura 4. SDS-PAGE de sobrenadantes de suspensão de $\mathrm{Cl}$ de NS1 de DENV incubados em pressão atmosférica (A) ou em alta pressão (B) em pH 7,0 a 12,0

Figura 5. Efeito da alta pressão sobre o desenovelamento da proteína NS1 de DENV. Fluorescência intrínseca máxima. .33

Figura 6. Efeito da $\mathrm{GdnHCl}, \mathrm{pH}$ e arg sobre o reenovelamento de NS1 de DENV. Solubilização monitorada por espectofotometria a $280 \mathrm{~nm}$ 35

Figura 7. SDS-PAGE. Sobrenadantes de Cl de NS1 de DENV submetidos à reenovelamento pela aplicação de alta pressão em pH 10,5 e 11,0 e na ausência e presença de $0,4 \mathrm{M}$ de $\arg$.

Figura 8. Cromatogramas em coluna de exclusão molecular de sobrenadantes de suspensões de $\mathrm{Cl}$ de NS1 de DENV. 39

Figura 9. SDS-PAGE. Sobrenadantes de $\mathrm{Cl}$ de NS1 de DENV submetidos à pressão em pH 10,5 e 11,5 na presença de 0,4M de arg e DTT (2mM) e de $1 \mathrm{~mm}$ GSH e $0,1 \mathrm{~mm}$ de GSSG.

Figura 10. Avaliação da reatividade da proteína NS1 de DENV obtida em diferentes condições de reenovelamento. 42

Figura 11. Avaliação da preservação de epítopos conformacionais na proteína NS1 de DENV.

Figura 12. Avaliação da reatividade da proteína NS1 de dengue obtida em diferentes condições de reenovelamento.

Figura 13. Avaliação da preservação de epítopos conformacionais da proteína NS1 de DENV obtida em diferentes condições de reenovelamento 
Figura 14. Avaliação da reatividade da proteína NS1 de DENV obtida em diferentes condições de tempo de descompressão

Figura 15. Avaliação da preservação de epítopos conformacionais da proteína NS1 de DENV obtida em diferentes condições de tempo de descompressão.

Figura 16. Curva de BSA e amostras de NS1 de DENV reenoveladas em pH 10,5 e 11,0 analisadas por SDS-PAGE.

Figura 17. Efeito da alta pressão sobre suspensões de CI de NS1 de ZIKV. Gráficos de Espalhamento de Luz.

Figura 18. Efeito da alta pressão sobre o desenovelamento da proteína NS1 de ZIKV. Gráficos de fluorescência intrínseca máxima. 56

Figura 19. Efeito da GdnHCl, pH e arg sobre o refolding de NS1 de ZIKV. Solubilização monitorada por espectofotometria a $280 \mathrm{~nm}$ 58

Figura 20. Cromatogramas em coluna de exclusão molecular de sobrenadantes de suspensões de $\mathrm{Cl}$ de NS1 de ZIKV.... 60

Figura 21. Amostras de NS1 ZIKV reenoveladas pela aplicação de alta pressão (2,4 kbar/0,4 kbar) em pH 11,0 e 11,5 na ausência e presença de 0,4M de arg, analisadas por SDS-PAGE. 61

Figura 22. SDS-PAGE para analise de sobrenadantes de CI de NS1 ZIKV submetidos à pressão em pH 11,0 e 11,5 na presença de $0,4 \mathrm{M}$ de arg e na presença ou ausência de $1 \mathrm{~mm}$ GSH e 0,1 mm de GSSG. .62

Figura 23. Avaliação da reatividade da proteína NS1 de ZIKV obtida em diferentes condições de refolding....

Figura 24. Avaliação da preservação de epítopos conformacionais da proteína NS1 de ZIKV obtida em diferentes condições de refolding.

Figura 25. Curva de BSA e amostras de NS1 de ZIKV reenovelada em pH 11,0 e 11,5 analisadas por SDS-PAGE 66 


\section{LISTA DE ABREVIATURAS}

$\begin{array}{ll}\mu & \text { Micro } \\ \text { A } & \text { Absorbância } \\ \text { aa } & \text { Aminoácidos } \\ \text { arg } & \text { Arginina }\end{array}$

BSA Albumina bovina sérica

CAPS 3-(Cyclohexylamino)-1propanesulfonic acid

CHIKV vírus da chikungunya

$\mathrm{Cl} \quad$ Corpos de inclusão

D.O. Densidade óptica

$\mathrm{Da} \quad$ Daltons

DENV Vírus da dengue

DTT 1,4-ditiotreitol

E. coli Escherichia coli

EDTA Ácido etilenodiamino tetra-acético

EL Espalhamento de luz

ELISA Enzyme-Linked Immunosorbent Assay

g Força centrífuga relativa

$\mathrm{GdnHCl}$ Hidrocloreto de guanidina

GFP green fluorescent protein

GSH Glutationa reduzida

GSSG Glutationa oxidada

IPTG Isopropyl $\beta$-D-tiogalactopiranosídeo

M Mol

ng Nanogramas

OPD 1,2-Diaminobenzeno 1,2-Phenilenodiamina

PAGE Eletroforese em gel de poliacrilamida

$\mathrm{pH} \quad$ Potencial hidrogeniônico

SDS Dodecil sulfato de sódio

Tris Tris (hidroximetil)aminometano 


\section{Trp Triptofano}

Tween 20 Polioxietileno sorbitol monolaureato

WNV Vírus do oeste do Nilo

YFV Vírus da febre amarela

ZIKV Vírus da zika 


\section{SUMÁRIO}

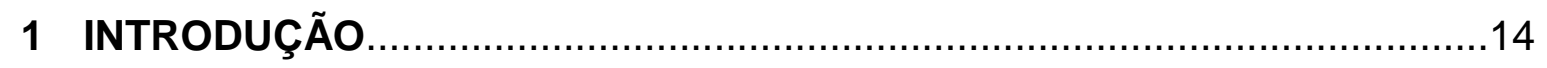

1.1 Efeitos da alta pressão sobre as proteínas........................................15

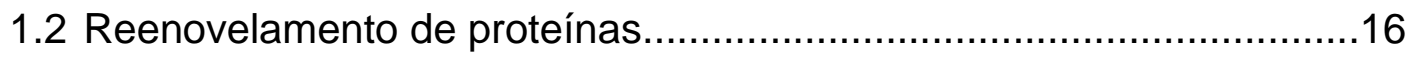

1.3 Aplicações de proteínas recombinantes de DENV e de ZIKV em

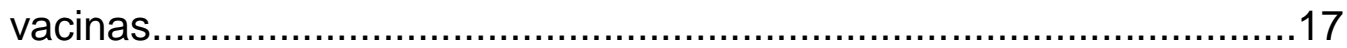

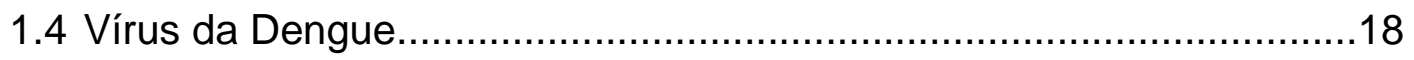

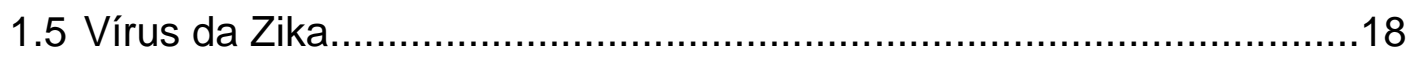

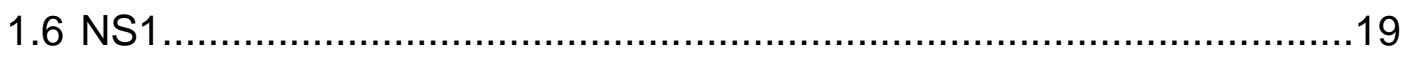

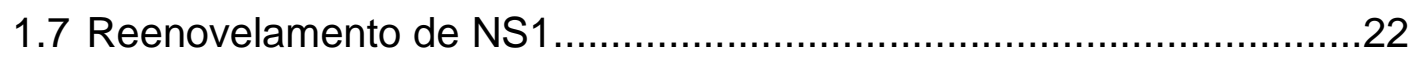

2 OBJETIVOS

3 METODOLOGIA

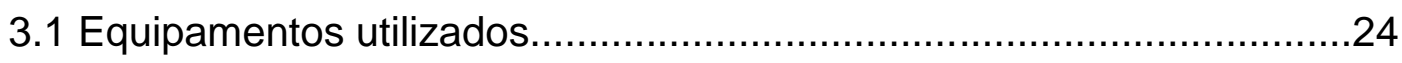

3.2 Expressão das proteínas recombinantes, lise bacteriana e lavagens

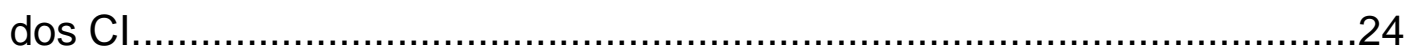

3.3 Medidas de fluorescência e espalhamento de luz (EL).......................25

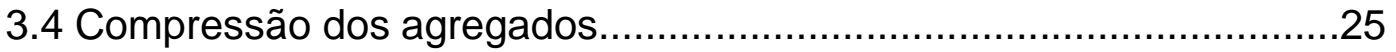

3.5 Eletroforese em gel de poliacrilamida (SDS-PAGE)........................27

3.6 Purificação e análise em coluna de exclusão molecular.......................27

3.7 ELISA (Enzyme-Linked Immunosorbent Assay)..........................28

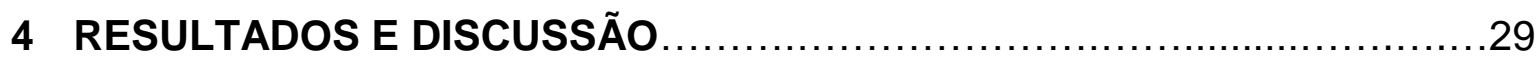

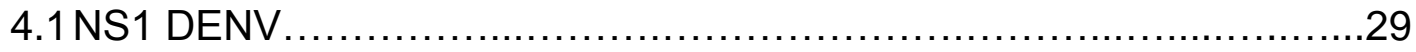

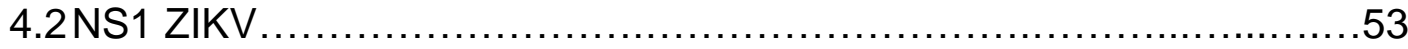

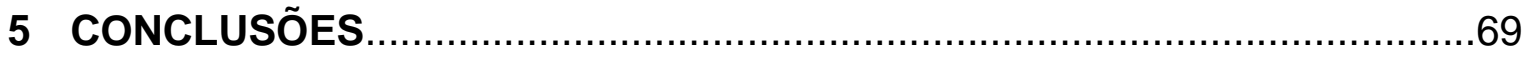

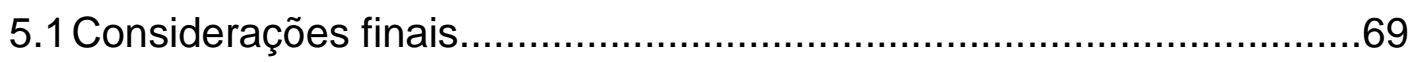




\section{INTRODUÇÃO}

Muitas das proteínas de valor biomédico relevante são encontradas em baixas concentrações em suas fontes nativas. A bactéria Escherichia coli é um microorganismo extremamente útil não só para a produção de proteínas de interesse comercial em grande escala, como também para a expressão de proteínas para estudos estruturais e funcionais.

A expressão de proteínas recombinantes em $E$. coli no estado solúvel no citoplasma é geralmente eleita como a forma preferida de expressão, pois estes compostos usualmente adquirem um estado similar ao nativo sem a necessidade de processamento posterior. No entanto, certas proteínas possuem a tendência à formação de ligações intermoleculares ao custo de contatos intramoleculares característicos das proteínas nativas e tendência à agregação e acúmulo de corpos de inclusão $(\mathrm{Cl})$ no citoplasma ou no espaço periplásmico das células hospedeiras (DE GROOT; VENTURA, 2006).

Foi recentemente estudado o efeito da temperatura de cultivo das bactérias hospedeiras nas características das proteínas recombinantes agregadas e se demonstrou que a bioatividade nos agregados possui correlação inversa com a temperatura de cultivo bacteriano e que os $\mathrm{Cl}$ se tornam mais estáveis à desnaturação química com o aumento de temperatura (DE GROOT; VENTURA, 2006). O cultivo das bactérias hospedeiras em altas temperaturas promove a formação de agregados mais estáveis, pois esta condição favorece interações intermoleculares à custa de ligações intramoleculares nativas (CARRIO et al., 2005). Inicialmente as proteínas nos $\mathrm{Cl}$ eram consideradas como totalmente inativas. No entanto, o conhecimento atual evoluiu e hoje em dia se reconhece que proteínas agregadas em Cl não são necessariamente inativas. Se demonstrou que as proteínas nos $\mathrm{Cl}$ possuem estruturas secundárias semelhantes àquelas das proteínas em seu estado nativo (AMl et al., 2006) e que existe certa porcentagem de estados com estrutura terciária nativa e atividade biológica nos $\mathrm{Cl}$ de green fluorescent protein (GFP) (MALAVASI et al., 2014; VERA et al., 2007) e de outras proteínas (GATTI-LAFRANCONI et al., 2011). Estes resultados podem ser importantes para a produção de proteínas recombinantes com conformação 
semelhante às correspondentes nativas a partir de $\mathrm{Cl}$, caso os estados puderem ser liberados utilizando-se condições que quebrem a rede de ligações intermoleculares que mantém a sua estabilidade sem desnaturar as proteínas incrustadas nos agregados proteicos produzidos em E. coli, o que elevaria o rendimento de reenovelamento posterior pela diminuição da reagregação.

Estabelecer um protocolo simples e eficiente para o reenovelamento de proteínas agregadas ainda se trata de uma tarefa difícil (BURGESS, 2009). Devido a essa dificuldade, pesquisadores da área de imunologia que trabalham com proteínas recombinantes heterólogas para preparação de vacinas frequentemente abandonam os estudos com moléculas potencialmente interessantes, quando produzidas como Cl. Gostaríamos ainda de lembrar que existe ao menos uma vantagem da expressão de proteínas como $\mathrm{Cl}$ sobre a sua produção na forma solúvel, que é a possibilidade de separação física entre os contaminantes solúveis do hospedeiro e os agregados insolúveis, elevando a pureza da proteína alvo. Assim, a utilização de protocolos eficientes de extração e lavagens dos $\mathrm{Cl}$ e de reenovelamento podem dispensar etapas de purificação, que costumam ser trabalhosas e caras.

\subsection{Efeitos da alta pressão e de pH alcalino sobre as proteínas}

Os efeitos da pressão nas interações entre segmentos de subunidades de uma proteína com estrutura quaternária ou entre ligações intramoleculares são ditados por reações similares, que produzem essencialmente o desvio do equilíbrio em favor dos reagentes que ocupam o menor volume. Quando em soluções aquosas e em altas pressões, as proteínas são infiltradas por água. A aplicação de pressão pode produzir uma população de diferentes conformações proteicas, incluindo estados parcialmente ou completamente desenovelados, exibindo maior entropia do que o estado nativo (SILVA et al., 2001). A entrada de água nas regiões hidrofóbicas das proteínas sob alta pressão promove a solubilização de agregados pelo fato de desfavorecer interações hidrofóbicas e eletrostáticas intramoleculares (CRISMAN; RANDOLPH, 2009; RANDOLPH et al., 2002).

A maioria das proteínas somente sofre desnaturação em pressões acima de 5 kbar (SILVA; WEBER, 1993) e algumas proteínas não são desenoveladas pela ação da pressão em níveis de até 13-14 kbar (SCHEYHING et al., 2002). Em nossos estudos utilizamos níveis de pressão abaixo de 3 kbar, pressão insuficiente 
para promover a desnaturação da maioria das proteínas, mas que é capaz de facilitar a dissociação dos agregados proteicos.

A utilização de pH alcalino também é capaz de promover a dissociação de agregados proteicos devido à repulsão eletrostática (YASOTHAl; GIRIPRASAD, 2015). O pH alcalino pode ser menos desnaturante do que altos níveis de agentes caotrópicos, como demonstrado pela análise por dicroísmo circular da proteína soroalbumina bovina (BSA) em pH alcalino. Em pH de 11,2 não ocorre perda de estruturas secundárias, enquanto em $6 \mathrm{M}$ de $\mathrm{GndHCl}$ o sinal de dicroismo circular é completamente abolido. Entretanto, neste pH a BSA perde por volta de $40 \%$ de estrutura terciária e passa a um estado denominado de glóbulos fundidos (SEN et al., 2008).

\subsection{Reenovelamento de proteínas}

O reenovelamento a partir de agregados não nativos e corpos de inclusão requer que as proteínas sejam solubilizadas e então reenoveladas para a obtenção de uma conformação próxima a nativa. Comumente, agregados de proteínas em corpos de inclusão são solubilizados em agentes caotrópicos fortes (hidrocloreto de guanidina ou uréia) em altas concentrações, o que resulta na desnaturação (ou desenovelamento) das moléculas de proteína. Uma vez solúveis e desnaturadas, as proteínas são primeiramente diluídas e então se busca o seu reenovelamento pela remoção do agente caotrópico por diálise, diluição adicional ou ainda outro processo. Geralmente a agregação é favorecida sobre o reenovelamento, principalmente em concentrações proteicas altas (CLARK, 1998). Encontrar as condições que levem a rendimentos aceitáveis de reenovelamento, se possível, requer a avaliação de um grande número de condições (RATHORE et al., 2013; VINCENTELLI et all., 2004).

Já foi demonstrada a elevação da eficácia de estratégias de reenovelamento que utilizam condições de solubilização brandas, que possibilitam a preservação de estruturas secundária e terciária, em comparação com a solubilização utilizando altas concentrações de agentes desnaturantes, no qual as proteínas perdem completamente a sua conformação (SINGH. A. et al., 2015).

A utilização de pressão para favorecer a dissociação e o reenovelamento de proteínas agregadas foi descrita pela primeira vez em 1999 por dois grupos, um deles brasileiro (Dra. Debora Foguel do Instituto de Bioquímica 
Médica da UFRJ) (FOGUEL et al., 1999; ST JOHN et al., 1999). A seguir, foram reportados outros estudos, alguns inclusive do nosso grupo de pesquisa, em que esta propriedade física foi utilizada para a dissociação de agregados e reenovelamento de proteínas (MALAVASI et al., 2011; ST JOHN et al., 2001, 2002). Entretanto, na maioria dos casos, a alta pressão sozinha não é eficaz para promover a solubilização completa dos $\mathrm{Cl}$ e por este motivo é necessária a utilização concomitante de concentrações de agentes desnaturantes como o $\mathrm{GdnHCl}$ para a solubilização eficiente dos $\mathrm{Cl}$ e subsequente reenovelamento (CHURA-CHAMBI et al., 2008, 2013; ; ST JOHN et al., 2001, 2002).

A utilização de $\mathrm{pH}$ alcalino também foi descrita como uma técnica relativamente branda de solubilização de agregados proteicos, com reenovelamento subsequente eficiente. Entretanto, a utilização de $\mathrm{pH}$ alcalino também não é suficiente para promover a solubilização eficiente dos agregados e a presença de certa concentração de agente desnaturante (2M de uréia) é necessária também nestes casos (PATRA et al., 2000; SINGH, S. e PANDA, 2005; SINGH, S. et al., 2008).

A utilização concomitante dos dois fatores: altas pressões hidrostáticas e pH alcalino não foi descrita para a solubilização de agregados proteicos e subsequente renovelamento.

\subsection{Aplicações de proteínas recombinantes de DENV e de ZIKV em vacinas}

Inicialmente as vacinas foram desenvolvidas de forma empírica, com base na atenuação ou inativação de patógenos. Avanços nas áreas de imunologia, biologia molecular, bioquímica, genômica e proteômica acrescentaram novas perspectivas para este campo. Pesquisas voltadas para o uso de proteínas recombinantes possibilitam o direcionamento de respostas imunes focadas em antígenos que se demonstraram capazes de promover respostas imunes protetoras e podem ser uma alternativa promissora para o desenvolvimento de vacinas eficazes e seguras. No entanto, tem sido demonstrada a importância de domínios antigênicos contendo epítopos com a conformação nativa para a geração de anticorpos neutralizantes (AMORIM et al., 2010). Há, portanto, a necessidade de obtenção de proteínas recombinantes que mantenham suas propriedades conformacionais preservadas. Outra aplicação muito importante de proteínas recombinantes de patógenos é a utilização em ensaios diagnósticos. Por este 
motivo, há a necessidade de produção de proteínas recombinantes com propriedades conformacionais das proteínas alvo dos patógenos preservadas, e, consequentemente do desenvolvimento de processos eficientes de reenovelamento nos casos em que as proteínas são produzidas como $\mathrm{Cl}$.

\subsection{Vírus da Dengue (DENV)}

A Dengue é a mais importante arbovirose que afeta o ser humano, constituindo-se em sério problema de saúde pública no mundo. Ocorre e dissemina-se especialmente nos países tropicais e subtropicais, onde as condições do meio ambiente favorecem o desenvolvimento e a proliferação do vetor Aedes aegypti, mosquito que também transmite o ZIKV, e os vírus da chikungunya (CHIKV) e da Febre Amarela (YFV). A Dengue é causada por quatro sorotipos distintos de vírus (DENV 1 a 4) (MURRAY et al., 2013). Acreditase que uma vacina que não seja capaz de gerar imunidade neutralizante contra os quatro sorotipos virais pode oferecer risco na indução de formas graves da dengue, pois os anticorpos gerados durante uma infecção anterior causada por um sorotipo diferente seriam capazes de se ligar às partículas virais do segundo sorotipo. Este processo facilitaria a entrada de vírions em novas células do hospedeiro, proporcionando o aumento da carga viral, a intensidade da resposta inflamatória e danos em células endoteliais que, em conjunto, causariam a forma hemorrágica da doença (GUZMAN et al., 2010; WHITEHEAD et al., 2007). Por isso, existe a necessidade de desenvolvimento de uma formulação vacinal tetravalente. Uma dificuldade para o desenvolvimento de uma vacina é a falta de conhecimento sobre os principais epítopos alvo para a geração de anticorpos neutralizantes. Por isso a definição de epítopos da NS1 de DENV capazes de gerar anticorpos neutralizantes, porém incapazes de promover a amplificação viral em células que reconheçam anticorpos contra outro sorotipo faz parte dos objetivos do grupo do Dr. Luis Carlos de Souza Ferreira, do Instituto de Ciências Biomédicas da USP, nosso colaborador. Uma aplicação extremamente importante de proteínas da DENV é a utilização em ensaios imunodiagósticos.

\subsection{Vírus da Zika (ZIKV)}

Evidências cada vez mais contundentes indicam que infecções pelo ZIKV estão ligadas à microcefalia fetal e de recém-nascidos, e sérias complicações 
neurológicas como a síndrome de Guillain-Barré (CALVET et al., 2016). A disponibilização de testes diagnósticos que permitam a determinação de anticorpos IgG e IgM ZIKV-específicos se torna fundamental para o tratamento clínico e para o planejamento de ações em saúde pública. Atualmente, não existem ensaios sorológicos disponíveis no mercado para o ZIKV que não apresentem reação cruzada falso-positiva com soros de indivíduos infectados por outras arboviroses, como a DENV e CHIKV. Um fato que piora o quadro é que estas viroses apresentam circulação concomitante com a ZIKV no Brasil atualmente. Além disso, soros de indivíduos que tenham adquirido imunidade para essas viroses por imunização também podem se apresentar positivos. Testes de RT-PCR utilizando oligonucleotídeos iniciadores específicos foram descritos para o diagnóstico de ZIKV (BALM et al., 2012). Entretanto, este método somente é sensível para a determinação de RNA de ZIKV na fase aguda da doença e apresenta resultado negativo após o período de viremia. É necessária, portanto, a produção de antígenos DENV e ZIKV-específicos que possam ser utilizados em ensaios sorológicos.

O ZIKV é um vírus de RNA simples fita da família Flaviviridae, que inclui vários outras viroses transmitidos por mosquitos, como DENV, vírus do oeste do Nilo (WNV) e o vírus da febre amarela (YFV) (LANCIOTTI et al., 2008). Do mesmo modo que outros flavivírus, o genoma do ZIKV é composto de 2 regiões não codificantes (5' e 3') que flanqueiam uma região que codifica para uma poliproteína que é clivada em capsídeo $(\mathrm{C})$, precursor de proteína de membrana (prM/M), envelope (E) e 7 proteínas não estruturais (NS1, NS2A, NS2B, NS3, NS4A, NS4B e NS5) (KUNO; CHANG, 2007).

Poucos artigos foram publicados sobre a biologia viral do ZIKV e por isso, os conhecimentos já adquiridos sobre as proteínas virais que são indutoras de anticorpos neutralizantes e de imunidade celular para outros flavivírus são fundamentais para o avanço no desenvolvimento de vacinas contra o ZIKV.

\subsection{NS1}

A NS1 de flavivírus é uma proteína com características interessantes para utilização como antígeno vacinal (AMORIM et al., 2014). Ela se associa a lipídeos da membrana celular formando homodímeros dentro das células (SUTHAR et al., 2013). Ela é também secretada no espaço extracelular como uma partícula 
lipoproteica hexamérica que está envolvida na evasão imune e patogênese pela interação com componentes de ambos os sistemas, inato e adaptativo, bem como com outros fatores do hospedeiro (AVIRUTNAN et al., 2010; CHUNG et al., 2006). Esta proteína é o mais importante marcador antigênico para infecção viral (YOUNG et al., 2000). A administração de formulações baseadas na proteína NS1 recombinante de DENV-2 foi capaz de promover proteção em camundongos desafiados com este subtipo viral (AVIRUTNAN et al., 2011). Os mecanismos moleculares da NS1 são relativamente bem estabelecidos para a DENV e para o WNV (AKEY et al., 2014; EDELING et al., 2014).

As NS1 de diferentes flavivírus possuem alta homologia entre si, apresentam massa molecular de 46-55 kDa dependendo do grau de glicosilação e seis pontes dissulfídicas intramoleculares invariáveis para os flavivírus, que são: C4-C15, C55-143, C179-C223, C280-C329, C291-C312, C313-C316 (EDELING et al., 2014; WALLIS et al., 2004). Esta proteína forma homodímeros em solução, que são mais imunogênicos e, portanto, mais interessantes para as aplicações em testes diagnósticos e como antígenos vacinais do que seus monômeros (ALLONSO et al., 2011), o que possivelmente se deve ao fato de os dímeros apresentarem epítopos no domínio de dimerização. A estrutura secundária dos monômeros é composta principalmente de folhas $\beta$, mas também apresenta duas $\alpha$-hélices, como mostrado na Figura 1, que representa a estrutura do monômero e dímero do vírus do oeste do Nilo (WNV) (AKEY et al., 2014). O dímero de NS1 é construído em volta de um domínio de folhas $\beta$. Cada monômero apresenta três domínios. Um domínio pequeno de dimerização (em azul na Figura $1 A, B$ e $C$ ) é formado por cilindros $\beta$ que formam dois grampos $\beta$, cada um deles estabilizado por uma ligação disulfeto. Os grampos $\beta$ se estendem atravessando o eixo de dimerização e se entrelaçam para formar uma folha $\beta$ de quatro cadeias que se curva para uma estrutura semelhante a um cilindro (em azul na Figura 1C). O segundo domínio de cada monômero sobressai do domínio $\beta$ central como uma asa (em amarelo na Figura 1). O terceiro domínio (em vermelho na Figura 1) é uma folha $\beta$ contínua que se estende ao longo do comprimento do dímero e é formada por 18 folhas $\beta$ arranjadas como os degraus de uma escada antiparalela (Figura $1 A$, em vermelho e cinza) em que cada monômero contribui com 9 degraus.

A estrutura cristalográfica de um fragmento C-terminal de NS1 de ZIKV (172-352) foi descrita revelando estruturas conservadas com a NS1 de outros 
flavivírus (SONG et al., 2016). A NS1 recombinante de ZIKV que iremos utilizar neste estudo possui 44,7 kDa de massa molecular e a de DENV possui 43,3 kDa. Ambas as proteínas recombinantes possuem 6 resíduos Histidina na porção $\mathrm{N}$ terminal.

Os pontos isoelétricos das proteínas recombinantes NS1 de DENV e de ZIKV são de 6,78 e 7,12 respectivamente.

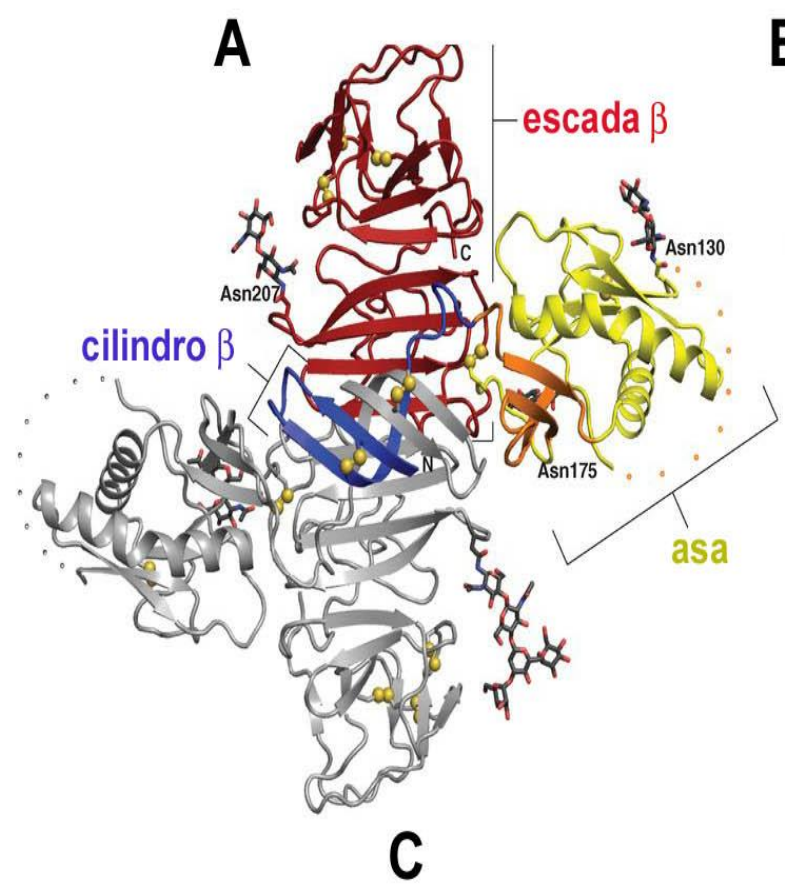

B
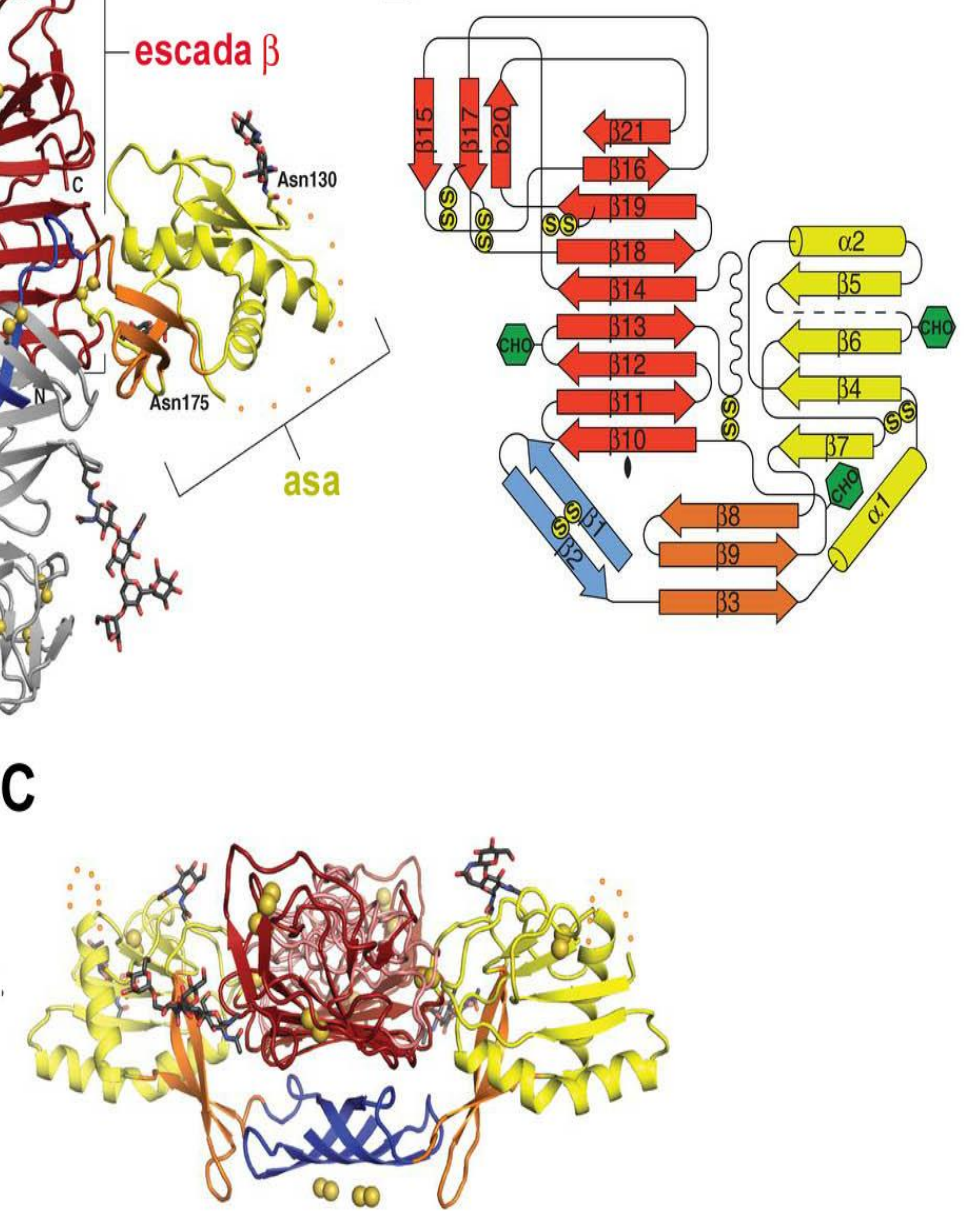

Figura 1. Estrutura do dímero de NS1 do vírus do oeste do Nilo (WNV) (AKEY et al., 2014). A, Dímero de NS1 com uma subunidade em cinza e outra colorida por domínios (azul: cilindro amarelo: asa com subdomínio conector em laranja, vermelho: escada central). O disulfetos estão representados como esferas amarelas e os sítios de $\mathrm{N}$-glicosilação são representados como bastões pretos. Uma região desordenada de 20 resíduos está indicada com linhas tracejadas. B, Diagrama de topologia para o monômero de NS1. Os sítios de glicosilação são indicados com haxágonos verdes e os disulfetos são representados como círculos amarelos. C, Vista perpendicular de dímero de NS1. 


\subsection{Reenovelamento de NS1}

Existem na literatura artigos descrevendo processos de reenovelamento da NS1 de DENV íntegra (ALLONSO et al., 2011; AMORIM et al., 2010; ATHMARAM et al., 2013; DAS et al., 2009; HUANG et al., 2001). Estes artigos relatam a utilização de ureia em alta concentração $(8 \mathrm{M})$ para a solubilização dos $\mathrm{Cl}$. Os rendimentos de reenovelamento foram relativamente baixos, de 10 a 30 $\mathrm{mg} / \mathrm{L}$ de cultura para Huang e colaboradores (2001), de $3,5 \mathrm{mg} / \mathrm{L}$ de cultura para Amorim e colaboradores (2010) e de $4,2 \mathrm{mg} / \mathrm{L}$ de cultura para Athmaran e colaboradores (2013). O rendimento obtido por Das e colaboradores (2009) foi de $139 \mathrm{mg} / \mathrm{L}$ de cultura, com $60 \%$ de obtenção de proteína purificada e reenovelada a partir da proteína expressa pelas bactérias, que foi de $250 \mathrm{mg} / \mathrm{L}$ de cultura. O artigo publicado por Allonso e colaboradores (2011) descreve um rendimento de $66 \%$ de obtenção de NS1 reenovelada. Não foi descrito processo de reenovelamento da proteína NS1 de ZIKV íntegra. Entretanto, foi descrita a obtenção de fragmentos de NS1 de ZIKV reenovelados a partir de CI (SONG e col., 2016) e de WNV (EDELING et al., 2014), porém os rendimentos obtidos não foram relatados.

Este estudo foi realizado em colaboração com o grupo do Dr. Luis Carlos de Souza Ferreira, do Instituto de Ciências Biomédicas da USP. 


\section{OBJETIVO}

Tendo em vista o fato de os processos de reenovelamento de proteínas descritos na literatura serem caros, trabalhosos e obterem baixo rendimento, o objetivo deste projeto é o reenovelamento/renaturação das proteínas recombinantes NS1 de DENV e de ZIKV produzidas como $\mathrm{Cl}$ em bactérias Escherichia coli fazendo uso de altas pressões para o desenvolvimento de um processo de reenovelamento mais rápido, de execução mais simples e com maior rendimento do que os métodos já descritos na literatura para a NS1 de DENV. Além disso, as NS1 reenoveladas devem apresentar características biológicas preservadas em relação à reatividade com anticorpos específicos de antígeno, incluindo soros de pacientes infectados com zikv e que, portanto, poderiam ser usados como antígeno para o desenvolvimento de vacinas ou testes de diagnóstico. 


\section{MATERIAIS E METODOLOGIA}

\subsection{Equipamentos utilizados}

Agitador, modelo Ts-2000', Vertex;

Aparelho Mili-Q Plus, purificador de água, Milipore;

Balança analítica, modelo ATX224, Shimadzu;

Balança semi-analítica, modelo UX620H, Shimadzu;

Banho-maria, modelo 100, Fanem;

Centrífuga refrigeradora automática, modelo 5810R, Eppendorf;

Coluna de exclusão molecular, modelo Superdex 200 10/300, GE Healthcare;

Espectrofluorímetro, modelo Cary Eclipse, Varian;

Espectrofotômetro, modelo Genesys 6, Thermo Scientific;

Estufa para cultura bacteriana, modelo Q-316B, Quimis;

Forno de microondas, LG;

Freezer $-20^{\circ} \mathrm{C}$, Bosch;

Incubadora refrigerada com agitação, modelo TE421, Tecnal;

Seladora a vácuo, modelo TM 150, TecMaq;

Sistema de Eletroforese vertical, modelo Tetra System, Bio-Rad;

Sonicador, modelo 3000, Biologics;

Vaso de alta pressão, modelo R4-6-40 e bomba, modelo P40, High Pressure Equipment.

\subsection{Expressão das proteínas recombinantes, lise bacteriana e lavagens dos $\mathbf{C l}$}

Para a expressão das proteínas NS1 de DENV tipo 2 e também de ZIKV foi utilizado o plasmídeo pET28a e como hospedeiras foram utilizadas bactérias Escherichia coli, cepa BL21(DE3) [F-, ampT, hsdS b $\left._{\mathrm{b}} \mathrm{rBmB}^{-}\right)$, gal, dcm $\lambda$ (DE3)] (Novagen EMD Biosciences, Inc.). As culturas para expressão das proteínas foram realizadas no laboratório do Dr. Luis Carlos de Souza Ferreira, do Departamento de Microbiologia do ICB-USP utilizando o meio de cultura LB e indução com densidade óptica (a $600 \mathrm{~nm}$ ) de 0,5, como descrito (AMORIM et al., 2010). As culturas induzidas ( 1 litro) foram centrifugadas a $8000 \mathrm{~g}$ por 10 minutos a $4^{\circ} \mathrm{C}$. $\mathrm{O}$ 
precipitado foi ressuspenso em $50 \mathrm{ml}$ do tampão $\mathrm{A} 1$ (0,1 M Tris- $\mathrm{HCl}$ pH 8,5 + $5 \mathrm{mM}$ EDTA). Em seguida foi adicionada lisozima $(50 \mu \mathrm{g} / \mathrm{mL})$ à suspensão e esta foi incubada em temperatura ambiente por 15 minutos. A seguir adicionou-se $0,1 \%$ de deoxicolato de sódio. A lise bacteriana foi realizada pela sonicação da suspensão em gelo para evitar aquecimento até que a cultura ficasse líquida e então foi centrifugada a $8000 \mathrm{~g}$ por 10 minutos a $4{ }^{\circ} \mathrm{C}$. O sobrenadante foi desprezado. $\mathrm{O}$ precipitado foi ressupenso em $50 \mathrm{~mL}$ do tampão $\mathrm{A} 2(0,1 \mathrm{M}$ Tris- $\mathrm{HCl}$ pH 8,5 + $5 \mathrm{mM}$ EDTA e $0,1 \%$ de deoxicolato de sódio) e a suspensão foi sonicada rapidamente para a desfazer os grumos. A suspensão foi centrifugada a $8000 \mathrm{~g}$ por 10 minutos a $4^{\circ} \mathrm{C}$ e a lavagem foi repetida novamente. A suspensão foi lavada uma vez com tampão $0,1 \mathrm{M}$ Tris $\mathrm{HCl}$ pH 8,5+1 mM EDTA e ressuspensa no mesmo tampão. Foi feita leitura em espectrofotômetro em $350 \mathrm{~nm}$ e as suspensões foram separadas em alíquotas de $1 \mathrm{~mL}$ que foram mantidas em freezer até o momento do uso.

\subsection{Medidas de fluorescência e espalhamento de luz (EL)}

As medidas de EL e fluorescência foram realizadas em um espectrofluorímetro Cary Eclipse (Varian). Os dados foram coletados utilizando cubetas de $1 \mathrm{~cm}$ de caminho óptico e as leituras foram realizadas em um ângulo de $90^{\circ}$ relativo à luz incidente utilizando um tempo de resposta de 1 segundo e velocidade de leitura de $240 \mathrm{~nm} /$ minuto. As medidas de EL foram realizadas com excitação em $320 \mathrm{~nm}$ e a emissão foi medida em 315 a $325 \mathrm{~nm}$. As medidas de fluorescência intrínseca do Triptofano (Trp) foram coletadas entre 300 e 400 nm, com excitação em $290 \mathrm{~nm}$.

Foram produzidas curvas de dissociação dos $\mathrm{Cl}$ pela ação de concentrações crescentes de $\mathrm{GdnHCl}(0$ a $3 \mathrm{M})$, de Arginina ( 0 a $0,6 \mathrm{M})$ ou de pHs crescentes ( 7 a 12).

\subsection{Compressão dos agregados}

Após o descongelamento das suspensões de Cl de NS1 de dengue ou zika foram refeitas as determinações das densidades ópticas das suspensões dos corpos de inclusão em tampão Tris $\mathrm{HCl}$ pH 8,5 em espectrofotômetro em comprimento de onda de $350 \mathrm{~nm}$ e as suspensões foram diluídos para a densidade 
óptica desejada, que foram de 1,0,2,0 ou de 5,0 e que correspondem a aproximadamente $90 \mu \mathrm{g} / \mathrm{mL}, 180 \mu \mathrm{g} / \mathrm{mL}$ e $450 \mu \mathrm{g} / \mathrm{mL}$, respectivamente.

Os tampões utilizados foram: Tris $\mathrm{HCl} 50 \mathrm{mM}$ para $\mathrm{pH}$ de 7,0 a 9,0 e CAPS $50 \mathrm{mM}$ para pH 10,0 a 12,0. A arginina (arg) apresenta caráter alcalino $(11,1)$ em solução aquosa. Para preparação de tampões com $\arg \mathrm{pH} 10,5$ se utilizou Tris $\mathrm{HCl} 50 \mathrm{mM} \mathrm{pH} \mathrm{8,5} \mathrm{+} \mathrm{arg.} \mathrm{Para} \mathrm{a} \mathrm{preparação} \mathrm{de} \mathrm{tampão} \mathrm{com} \mathrm{arg} \mathrm{em} \mathrm{pH}$ 11,0 e 11,5 se utilizou tampão CAPS $50 \mathrm{mM} \mathrm{pH} \mathrm{11,0} \mathrm{e} \mathrm{pH} \mathrm{12,0} \mathrm{respectivamente.}$ Para o reenovelamento das proteínas utilizou-se $1 \mathrm{mM}$ de EDTA.

As amostras de suspensão de agregados proteicos foram colocadas em saquinhos plásticos que foram selados, colocadas dentro de outro saco plástico, que foi selado a vácuo e colocados no vaso de pressão (R4-6-40, High Pressure Equipment) (Figura 2). O vaso foi fechado e pressurizado em altas pressões (2,4 kbar) utilizando um sistema de ar comprimido e uma bomba adequada para alta pressão (PS-50, High Pressure Equipment), utilizando-se óleo como fluido de transmissão e foi mantida nesta condição por 90 minutos. A descompressão foi realizada lentamente até a pressão de 1 bar ou até a pressão de 0,4 kbar, condição na qual foi incubada por 6h30min ou 14h30min. Após a descompressão, as amostras foram centrifugadas a $12000 \times \mathrm{g}$ por 15 minutos para retirada de agregados insolúveis, dialisadas contra tampão adequado para abaixar o pH e para retirada de aditivos, novamente centrifugadas e estocadas a $-20^{\circ} \mathrm{C}$ para posterior análise. 


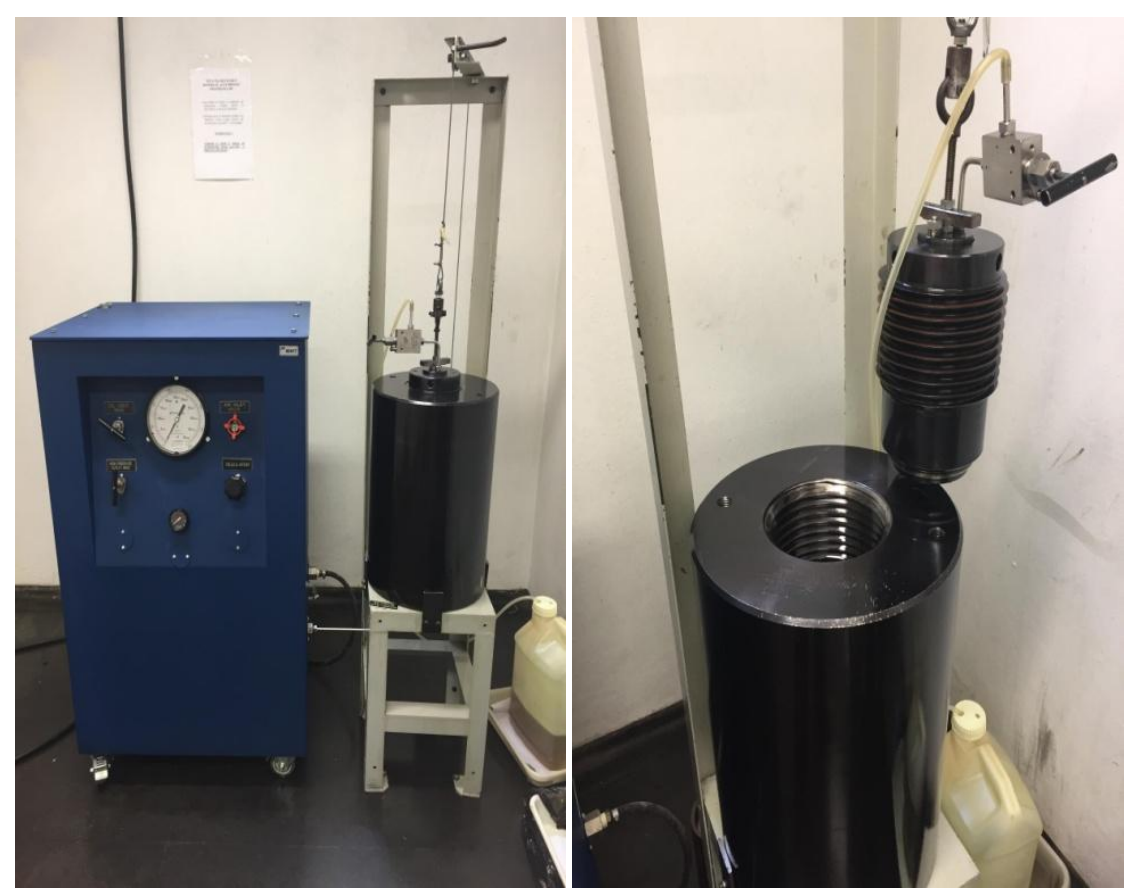

Figura 2. Bomba e vaso de alta pressão (High Pressure Equipment).

\subsection{Eletroforese em gel de poliacrilamida (SDS-PAGE)}

O SDS-PAGE foi realizado utilizando-se gel à $12 \%$, segundo o método descrito por LAEMMLI (1970) contendo SDS e coradas com Coomassie Blue G250. As suspensões de $\mathrm{Cl}$ foram aquecidas a $100^{\circ} \mathrm{C}$ por 5 minutos em tampão de amostra (50 mM de Tris- $\mathrm{HCl}$ pH 8.5 e $0.01 \%$ de bromofenol) ou não foram aquecidas, conforme indicado nas figuras. Para análise de proteínas em condição redutora, o tampão de amostra continha também 100 mM de 1,4 ditiotreitol (DTT).

\subsection{Purificação e análise em coluna de exclusão molecular}

A análise de amostras de NS1 de ZIKV e de DENV foi realizada em coluna de exclusão molecular Superdex 200 10/300 (GE Healthcare) acoplado a um sistema AKTA (GE Healthcare). Os tampões utilizados para ambientação da coluna e para eluição foram variados e por este motivo a indicação dos tampões utilizados constam nas figuras. 


\subsection{ELISA (Enzyme-Linked Immunosorbent Assay)}

Os ensaios de ELISA foram realizados em placas de 96 poços. Para a sensibilização das placas foram aplicados $100 \mu \mathrm{l}$ por poço dos antígenos diluídos para uma concentração de $2 \mathrm{ng} / \mu \mathrm{l}$ em tampão fosfo-salina (PBS). As placas foram incubadas a $4^{\circ} \mathrm{C}$ por 16 a 18 horas e lavadas em tampão de lavagem (PBS contendo 0,05\% de Tween-20). A seguir foram adicionados $200 \mu \mathrm{l}$ de tampão de bloqueio (PBS contendo $0,05 \%$ de Tween $20,3 \%$ de leite desnatado em pó e $1 \%$ de BSA) e incubadas a $37^{\circ} \mathrm{C}$ por 2 horas. Após este tempo o tampão de bloqueio foi desprezado de forma que não restasse nenhuma gotícula no poço. Foram adicionados $100 \mu \mathrm{l}$ de amostras de soro de pacientes positivos diluídas em tampão de diluição (PBS contendo 0,05\% de Tween 20,3\% de leite e $0,25 \%$ de BSA) em diluições de 1:200 a 1:12800 a cada poço e incubadas a temperatura ambiente por 1 hora. A seguir os poços foram lavados 3 vezes com $300 \mu \mathrm{l}$ de tampão de lavagem e a cada poço foram adicionados $100 \mu \mathrm{l}$ de anticorpo anti-lgG humano produzido em cabras, conjugado à peroxidase (A0170, Sigma Aldrich) diluído 3000 vezes em tampão de diluição e as placas foram incubadas a temperatura ambiente por 1 hora. A seguir as placas foram lavadas mais 3 vezes em tampão de lavagem. A revelação foi realizada pela adição de $100 \mu \mathrm{l}$ de tampão citrato-fosfato $33 \mathrm{mM}, \mathrm{pH} \mathrm{5,5}$ contendo 0,04\% de 1,2-Diaminobenzeno 1,2-Phenilenodiamina (OPD) e 0,04\% de peróxido de hidrogênio por poço e incubadas ao abrigo da luz por 15 minutos em temperatura ambiente. $O$ bloqueio da revelação foi realizado pela adição $50 \mu \mathrm{l}$ de ácido sulfúrico $1 \mathrm{M}$. As placas foram lidas em espectrofotômetro em comprimento de onda de $492 \mathrm{~nm}$. 


\section{$4 \quad$ RESULTADOS E DISCUSSÃO}

\subsection{NS1 de DENV}

O primeiro passo para estabelecimento de um processo de reenovelamento de proteínas é a solubilização dos agregados proteicos. Alguns artigos já utilizaram a aplicação de alta pressão para a solubilização de $\mathrm{Cl}$ de diferentes proteínas. Entretanto, na maioria dos casos, além da aplicação de alta pressão, é necessária a presença de agentes desnaturantes para a promoção eficiente da solubilização dos agregados (CHURA-CHAMBI et al., 2008; ST JOHN et al., t2001). Devido ao fato de que outros autores frequentemente utilizam arg 0,4M nos processos de reenovelamento da NS1 de outros flavivírus (ALLONSO et al., 2011; EDELING et al., 2014; SONG et al., 2016), nós também testamos a utilidade deste reagente para a solubilização da NS1. Com a finalidade de determinarmos se a associação de alta pressão e presença de $\mathrm{GdnHCl}$, de arg ou pH alcalino são capazes de promover a solubilização eficiente das proteínas NS1 nos CI de NS1 de DENV2 com baixa desnaturação da proteína nos agregados, suspensões de $\mathrm{Cl}$ de NS1 de DENV2 foram incubadas em pH de 7,0 a 12,0, em até $3 \mathrm{M}$ de $\mathrm{GdnHCl}(\mathrm{em} \mathrm{pH} \mathrm{8,5)}$ ou em até $0,6 \mathrm{M}$ de arg (em pH 10,5) em alta pressão (2,4 kbar por 90 minutos e 0,4 kbar por 16 horas) ou em pressão atmosférica. A queda nos valores de EL visível indica que a solubilização dos agregados foi muito eficiente quando as suspensões foram submetidas à alta pressão. Houve mais de $90 \%$ de queda nos valores de EL a partir de 1,0 M de GdnHCl (Figura 3A). O mesmo ocorreu quando a suspensão foi incubada em alta pressão em pH 10,0 (Figura 3B) e em pH 10,5 mesmo na ausência de arg (Figura $3 C)$. Entretanto, houve menor grau de queda nos valores de EL das suspensões que foram incubadas em 1 bar, o que indica que a solubilização dos agregados foi menos eficiente em pressão atmosférica. Também foram realizados testes em que as suspensões foram incubadas em alta pressão na presença de arg em pH 8,5 , porém a solubilização não foi eficiente como quando realizada em $\mathrm{pH}$ alcalino (dados não mostrados). 
A

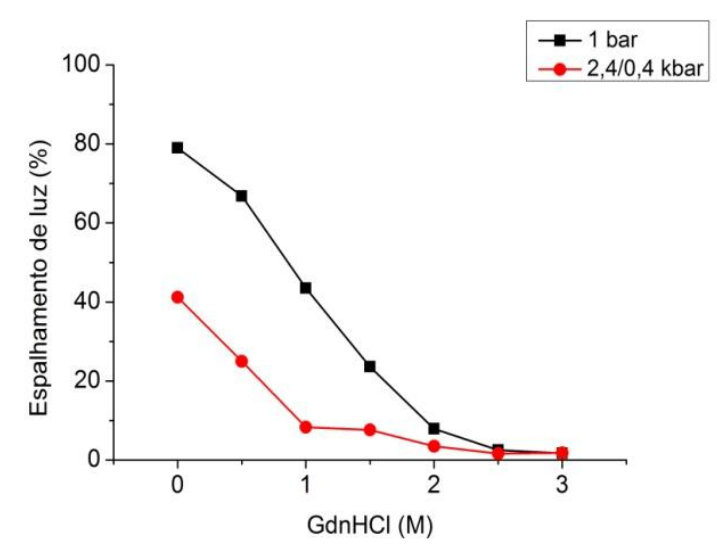

B

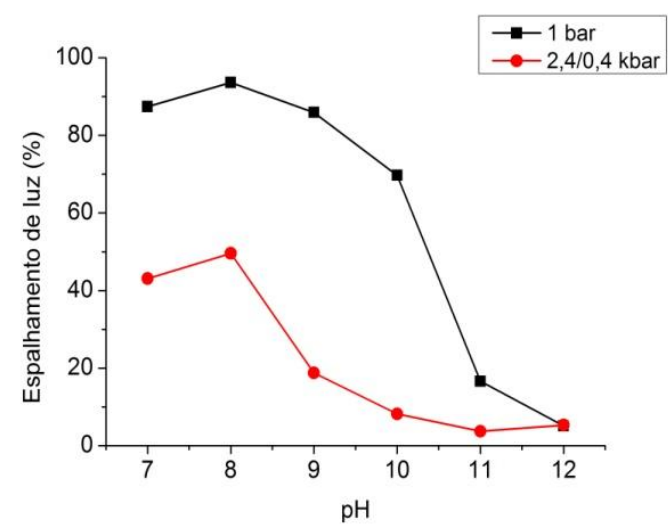

C

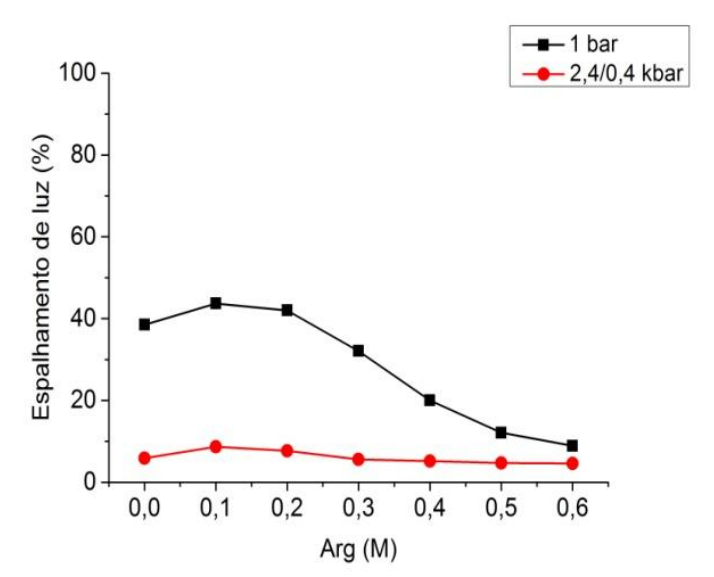

Figura 3. Efeitos da alta pressão sobre a solubilização da NS1 DENV. EL de suspensões de $\mathrm{Cl}$ de NS1 de DENV submetidos ou não à alta pressão (2,4 kbar/0,4 kbar). A: curva de $\mathrm{GdnHCl}$ em TrisHCl $50 \mathrm{mM} \mathrm{pH} \mathrm{8,5;} \mathrm{B:} \mathrm{curva} \mathrm{de} \mathrm{pH} \mathrm{em} \mathrm{tampão} \mathrm{Tris} \mathrm{HCl} 50 \mathrm{mM}$ (pH 7 a 9) e em tampão CAPS

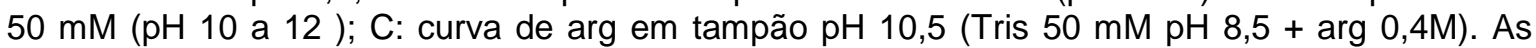
medidas foram realizadas em espectrofluorímetro e utilizou-se a excitação de $320 \mathrm{~nm}$ e a emissão foi determinada entre 315 e $325 \mathrm{~nm}$. O valor de EL obtido para a suspensão em pH 7,0 e leitura em tempo zero em 1 bar foi considerado como $100 \%$. 
A análise por SDS-PAGE dos sobrenadantes da suspensão de NS1 de DENV (Figura 4) incubadas em diferentes pH demonstra que a solubilização da NS1 só é eficaz em pH 12,0 quando a suspensão é incubada em pressão atmosférica (Figura 4A), mas que a aplicação de alta pressão é capaz de promover a solubilização desta proteína já em pH 10,0 e 11,0 (Figura 4B). Os dados obtidos pela eletroforese não coincidem com os dados obtidos de EL: citamos como exemplo a suspensão incubada em pH 9,0 e alta pressão, que apresentou um valor relativamente baixo de EL (Figura $3 \mathrm{~B}$ ), o que indica sua solubilização. Entretanto a banda na altura correspondente à proteína NS1 e pH 9,0 no gel de eletroforese da Figura 4B é muito fraca e só aparece quando em condição redutora. A suposição é de que a proteína tenha sido solubilizada, formando agregados solúveis que não são capazes de penetrar no gel de eletroforese.

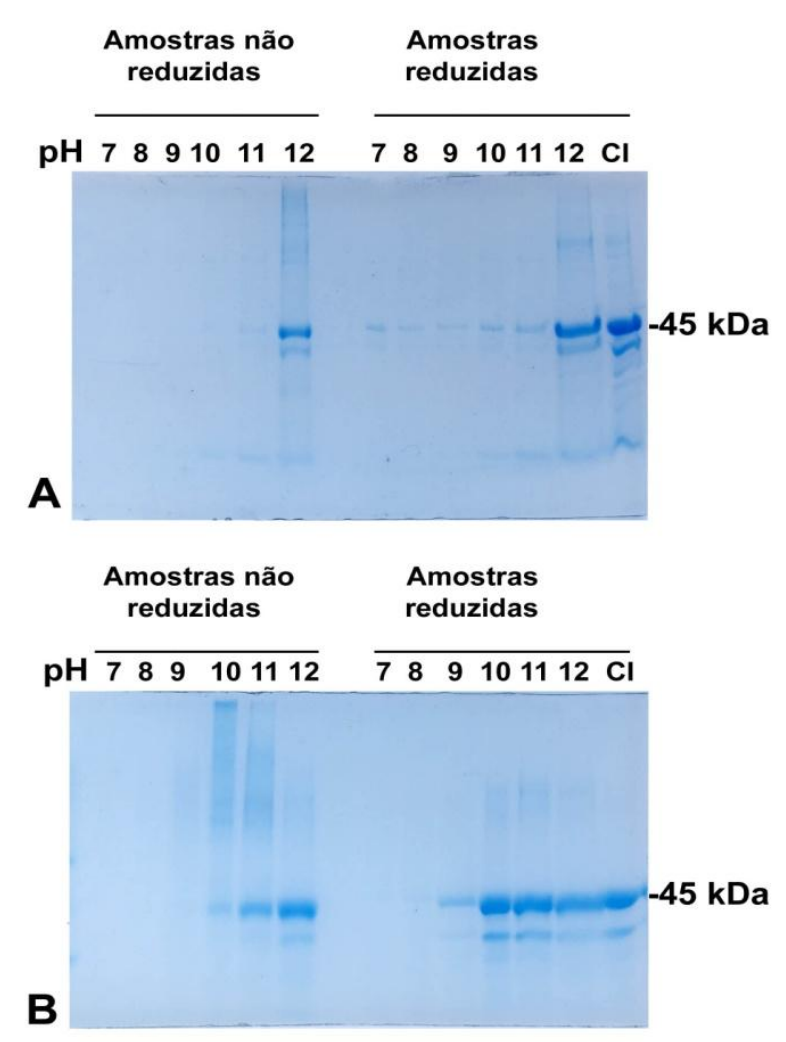

Figura 4. SDS-PAGE de sobrenadantes de suspensão de $\mathrm{Cl}$ de NS1 de DENV incubados em pressão atmosférica (A) ou em alta pressão (B) em pH 7,0 a 12,0. As suspensões foram mantidas em pressão atmosférica por 16 horas ou submetidas à 2,4 kbar por $1 \mathrm{~h} 30$ min e 0,4 kbar por $14 \mathrm{~h} 30 \mathrm{~min}$. As amostras não foram fervidas, com exceção da amostra de suspensão de $\mathrm{Cl}$ que foi fervida e reduzida. A redução foi obtida pela adição de $100 \mathrm{mM}$ de DTT nas amostras. 
O Trp é um excelente marcador fluorescente intrínseco devido ao fato de que o seu espectro de fluorescência se desloca para maiores comprimentos de onda conforme este resíduo hidrofóbico se torna mais exposto ao solvente, indicando maior grau de desnaturação das proteínas contendo este resíduo (BURSTEIN et al., 1973). A NS1 de DENV contém 14 resíduos de Trp (código de acesso no Protein Data Bank: PDB5K6K). Um pico de fluorescência intrínseca com intensidade máxima ( $\lambda$ máximo) em aproximadamente $340 \mathrm{~nm}$ foi descrito para esta proteína na conformação nativa, deslocando-se para $355 \mathrm{~nm}$ quando ocorre desnaturação (ALLONSO et al., 2011). Os Cl são compostos majoritariamente de NS1, e por este motivo consideramos que deslocamentos do pico de fluorescência do Trp para maiores comprimentos de onda indicam o desenovelamento desta proteína. A suspensão de $\mathrm{Cl}$ de DENV em $\mathrm{pH} 7$ apresenta um $\lambda$ máximo de $342,0 \mathrm{~nm}$, indicando que a NS1 incrustada nestes agregados se encontra em uma conformação mais semelhante à conformação nativa do que da conformação desnaturada. A desnaturação proteica total da NS1 nos $\mathrm{Cl}$, promovida na presença de $6 \mathrm{M}$ de $\mathrm{GdnHCl}$ promoveu o deslocamento do pico de Trp de 12,3 nm (para 354,5 nm). Os quatro fatores: aplicação de alta pressão, $\mathrm{pH}$ alcalino, presença de $\mathrm{GdnHCl} e$ de arg promovem 0 desenovelamento da proteína, como indicam os dados da Figura 5. A aplicação de alta pressão à supensão em $\mathrm{pH}$ alcalino promoveu $\mathrm{o}$ deslocamento para $\mathrm{O}$ vermelho dos picos de fluorescência de somente $2,9 \mathrm{~nm}$ em pH 10,0 e de 3,7 nm em $\mathrm{pH} 11,0$ para comprimentos de onda maiores (para $344,9 \mathrm{~nm}$ e $345,7 \mathrm{~nm}$, respectivamente), indicando exposição deste resíduo ao solvente e desenovelamento proteico parcial (Figura 5B). A presença de $0,4 \mathrm{M}$ de arg (em pH 10,5) promoveu deslocamento do pico de fluorescência de 4,6 nm (para 346,6 nm) (Figura 5C). No entanto, a condição que promoveu o maior grau de desnaturação da proteína foi a presença de $\mathrm{GdnHCl}$ : 1,0 M de $\mathrm{GdnHCl}$ promoveu um deslocamento da fluorescência, de $6,8 \mathrm{~nm}$ para $348,8 \mathrm{~nm}$, a presença de 1,5 $\mathrm{M}$ de $\mathrm{GdnHCl}$ promoveu um deslocamento de 9,6 $\mathrm{nm}$ para 351,6 nm e a presença de 2,5M de $\mathrm{GdnHCl}$ promoveu a desnaturação completa da proteína (Figura 5A). Os dados indicam que a solubilização dos $\mathrm{Cl}$ pela aplicação da pressão (Figura 3A, B e C) não foi acompanhada de completa desnaturação da NS1 nestes agregados (Figura 5). 
A

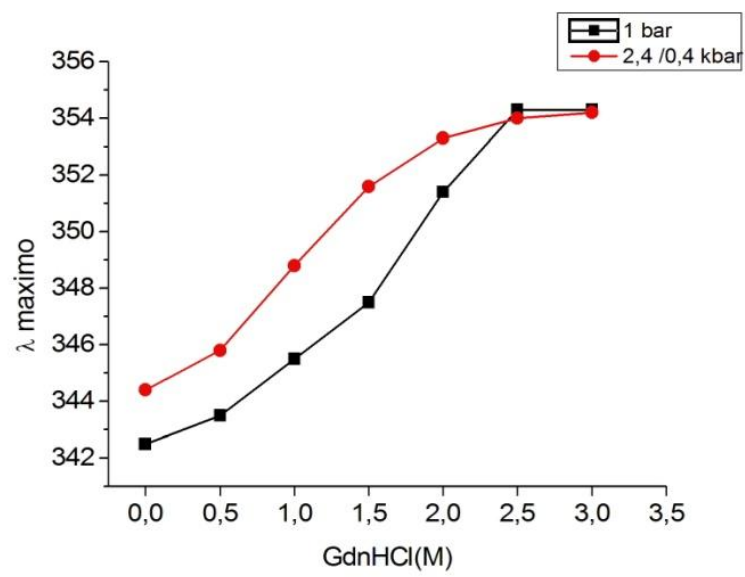

B

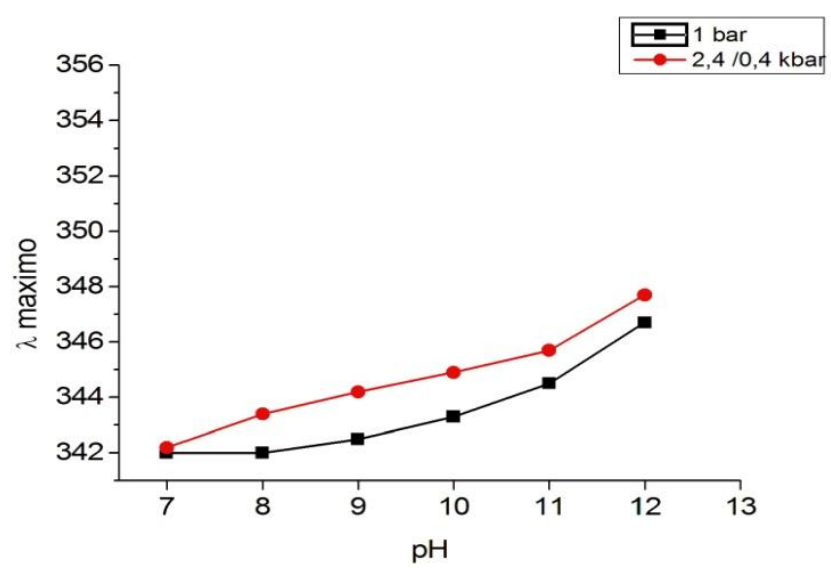

C

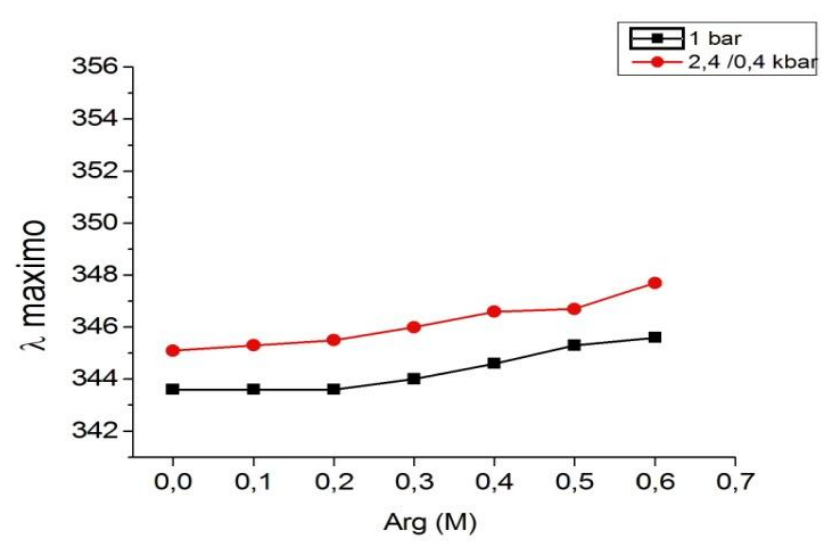

Figura 5. Efeito da alta pressão sobre o desenovelamento da proteína NS1 de DENV. Gráficos de fluorescência intrínseca máxima ( $\lambda$ máximo) dos $\mathrm{Cl}$ submetidos ou não à pressão $(2,4 \mathrm{kbar} / 0,4$ kbar). A: curva de GdnHCl em pH 8,5 ; B: Curva de pH; em pH 10,5; C: Curva de arg em pH 10,5. Os valores foram obtidos utilizando-se excitação de $290 \mathrm{~nm}$ e a emissão foi determinada entre 300 e $400 \mathrm{~nm}$. 
A concentração de NS1 nos sobrenadantes das suspensões de $\mathrm{Cl}$ submetidas à pressão nas condições mostradas na Figuras 3 e 5 e subsequentemente à diálise em TrisHCl $50 \mathrm{mM}$ pH 8,5 e centrifugação para retirada dos agregados insolúveis foram monitorados pela determinação de absorbância em $280 \mathrm{~nm}$. A proteína NS1 solubilizada na presença de GdnHCl se revelou altamente instável, mostrando alto grau de reagregação formando agregados insolúveis após diálise para retirada deste agente caotrópico, o mesmo não ocorrendo quando a suspensão foi solubilizada em $\mathrm{pH}$ alcalino. Este fenômeno está demonstrado nos gráficos apresentados na Figura 6 , que mostram a presença de uma concentração maior de NS1 solúvel nas amostras que foram submetidas à pressão em $\mathrm{pH}$ alcalino do que nas amostras que foram submetidas à pressão na presença de $\mathrm{GdnHCl}$. Portanto, na busca pelas condições ótimas para a reenovelamento de NS1 DENV, resolvemos continuar investindo nossos esforços utilizando as condições nas quais foram obtidos melhores resultados de rendimento de obtenção de proteína solúvel, que foi a associação de $\mathrm{pH}$ alcalino com a aplicação de alta pressão para solubilização dos CI de NS1 de DENV, na presença ou na ausência de arg. 
A

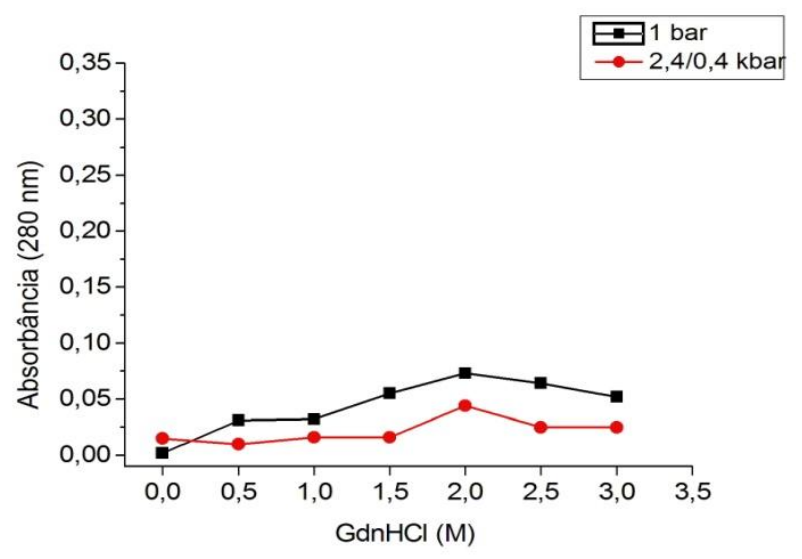

B

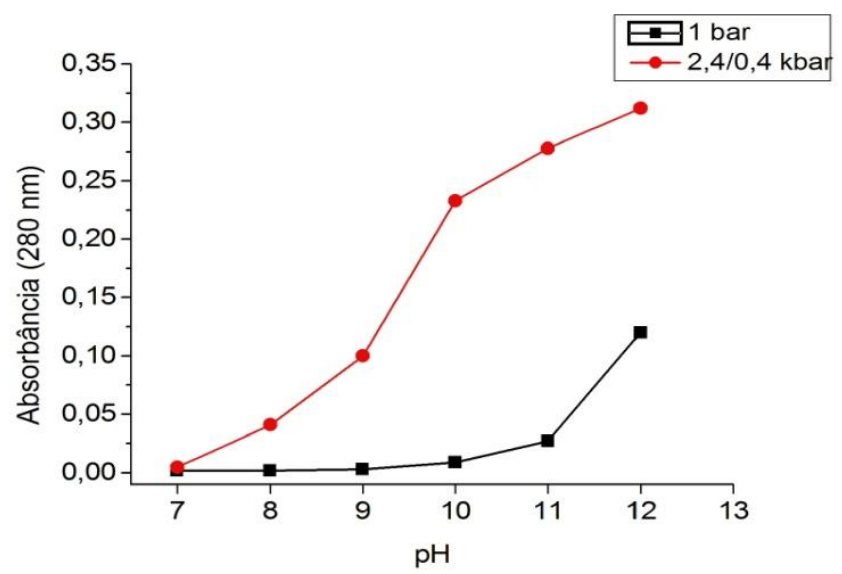

C

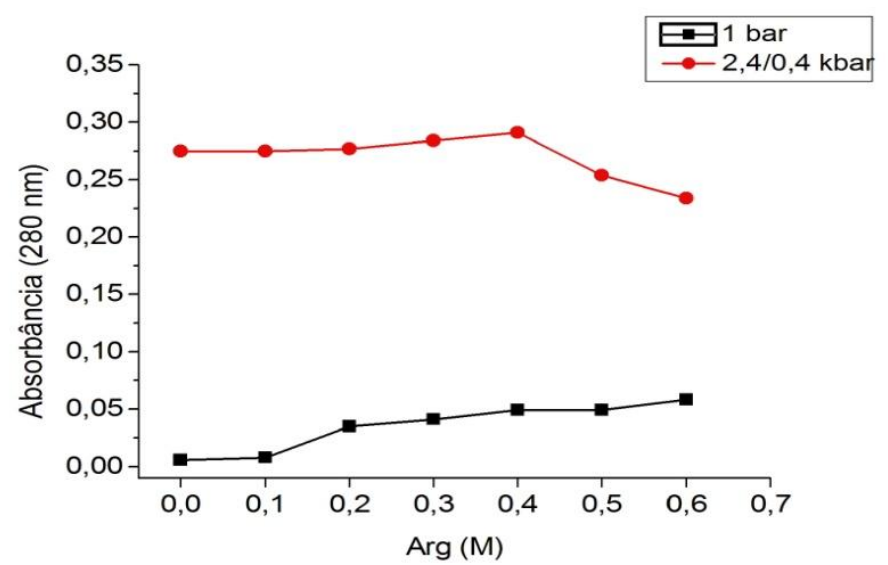

Figura 6. Efeito da $\mathrm{GdnHCl}$, pH e arg sobre o reenovelamento de NS1 de DENV. Solubilização monitorada por espectofotometria a $280 \mathrm{~nm}$ dos sobrenadantes de $\mathrm{Cl}$ submetidos e não submetidos à pressão $(2,4 \mathrm{kbar} / 0,4 \mathrm{kbar})$ e centrifugação para retirada dos agregados insolúveis e depois à diálise em tampão Tris $\mathrm{HCl} 50 \mathrm{mM} \mathrm{pH} \mathrm{8,5} \mathrm{e} \mathrm{nova} \mathrm{centrifugação.} \mathrm{A:} \mathrm{curva} \mathrm{de} \mathrm{GdnHCl}$ em pH 8,5; B: Curva de pH; C: Curva de arg em pH 10,5. 
Dados de SDS-PAGE em que foram aplicados os sobrenadantes das suspensões de $\mathrm{Cl}$ de NS1 incubados em alta pressão (2,4 kbar por 1h30min e 0,4 kbar por 14h30min) na ausência e na presença de arg 0,4M e dialisados, mostram a presença de bandas correspondentes a monômeros de NS1 (45 kDa), dímeros (90 kDa) e de formas de NS1 de alto peso molecular (Figura 7). Podemos observar a alta concentração de proteína no topo do gel no caso da amostra reenovelada na ausência de arg, enquanto a banda de monômero é mais forte no caso da amostra reenovelada com arg, o que sugere que a presença de arg durante a compressão elevou o rendimento de obtenção de NS1 monomérica a partir de oligômeros de alto peso molecular. $O$ fato de obtermos bandas com intensidade semelhante entre as amostras reenoveladas e a suspensão $(\mathrm{Cl})$ demonstra alto rendimento de obtenção de proteína solúvel. Através de análise do SDS-PAGE utilizando o programa Image $\mathrm{J}$, determinamos as porcentagens da NS1 reenovelada. Constatamos que a eficiência do reenovelamento de NS1 sem arg foi de aproximadamente $85 \%$ e de $98 \%$ para as amostras com arg.

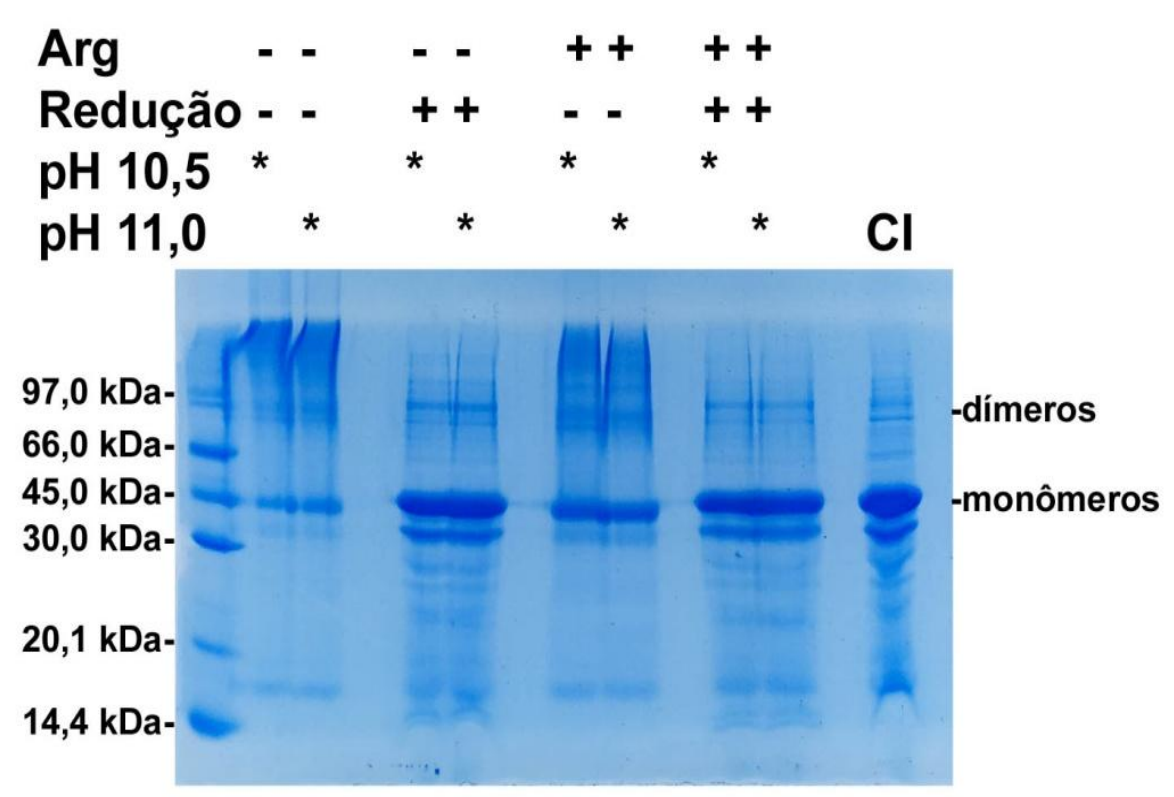

Figura 7. SDS-PAGE. Sobrenadantes de CI de NS1 de DENV submetidos à reenovelamento pela aplicação de alta pressão (2,4 kbar por $1 \mathrm{~h} 30 \mathrm{~min}$ e 0,4 kbar por $14 \mathrm{~h} 30 \mathrm{~min})$ em pH 10,5 e 11,0 e na ausência e presença de $0,4 \mathrm{M}$ de arg. A redução foi obtida pela adição de $100 \mathrm{mM}$ de DTT as amostras, somente a amostra de suspensão de $\mathrm{Cl}$ foi fervida. 
As análises da proteína NS1 solubilizada em pH alcalino e alta pressão foram também realizadas por cromatografia de exclusão molecular em coluna Superdex 200 10/300. Devido à semelhança de massas moleculares entre a DENV2 NS1 (45 kDa) e a ovalbumina, utilizamos esta proteína (massa molecular de $45 \mathrm{kDa}$ ) como padrão. Os volumes de retenção obtidos foram de $13,1 \mathrm{~mL}$ para o monômero, de 11,4 mL para o dímero e de 10,5 para o trímero de ovalbumina (dados não mostrados). Foram analisadas amostras de NS1 DENV submetidas à pressão de 2,4 kbar por 1h30min e 0,4 kbar por 14h30min em pH 10,0, 10,5, 11,0 e 11,5 na presença e ausência de arginina e posteriormente dialisadas contra Tris $50 \mathrm{mM} \mathrm{pH} 8,5$. Os cromatogramas da Figura 8 mostram a presença de picos com volumes de retenção de aproximadamente $8,4 \mathrm{~mL}$, que provavelmente são formas oligoméricas solúveis de NS1 de alto peso molecular. Pela comparação com os dados obtidos para a ovalbumina, os picos com eluição em aproximadamente $10,5 \mathrm{~mL}$ provavelmente são trímeros, os picos com volumes de aproximadamente $11,2 \mathrm{~mL}$ provavelmente se tratam de dímeros e os picos com volume aproximado de $12,9 \mathrm{~mL}$ provavelmente se tratam de monômeros de NS1. Nas amostras submetidas à pressão em pH 10,0 observamos a predominância de formas oligoméricas, o que mostra que a dissociação dos oligômeros não foi completamente efetiva. Entretanto esta dissociação aumenta de acordo com a elevação do pH. Em pH a partir de 11,0 na ausência de arg e a partir de 10,5 para as amostras comprimidas na presença de arg observamos majoritariamente a presença de trímeros, dímeros e monômeros de NS1 (Figura 8). Esses dados indicam que a presença de arg se mostrou relevante no processo de solubilização, tornando a dissociação dos oligômeros mais efetiva, o que corrobora os dados obtidos pela análise por SDS-PAGE (Figura 7).

Ainda na mesma figura pode-se observar que quanto mais elevado 0 $\mathrm{pH}$, menores os volumes de retenção do monômero de NS1: para o sobrenadante da suspensão de $\mathrm{Cl}$ submetida à pressão em pH 10,0 + arg o monômero eluiu em $12,9 \mathrm{~mL}$ e o pico referente ao monômero do sobrenadante da suspensão submetida à pressão em pH 10,5 + arg foi eluido em igual volume: 12,9 mL. O monômero do sobrenadante do $\mathrm{Cl}$ redobrado em pH 11,0 + arg foi eluido em 12,7 $\mathrm{mL}$ e o pico de monômero do sobrenadante dos $\mathrm{Cl}$ reenovelados em $\mathrm{pH} 11,5+$ arg, foi eluido em $12,5 \mathrm{~mL}$. A diminuição do volume de eluição com a elevação do 
$\mathrm{pH}$ ocorre também com os volumes de eluição dos trímeros e dímeros, mas não com o pico de oligômeros. Uma possível explicação para este fenômeno é a de que quanto mais alto o $\mathrm{pH}$, maior o desenovelamento da proteína, com elevação do volume da mesma. $O$ deslocamento é mais evidente em $\mathrm{pH}$ mais alcalino $(11,0$ e 11,5) e por este motivo, acreditamos que o ideal seria utilizar o pH de até 10,5 para a solubilização dos CI de NS1 DENV sob alta pressão. 
Oligom. Trím. Dím. Monômeros
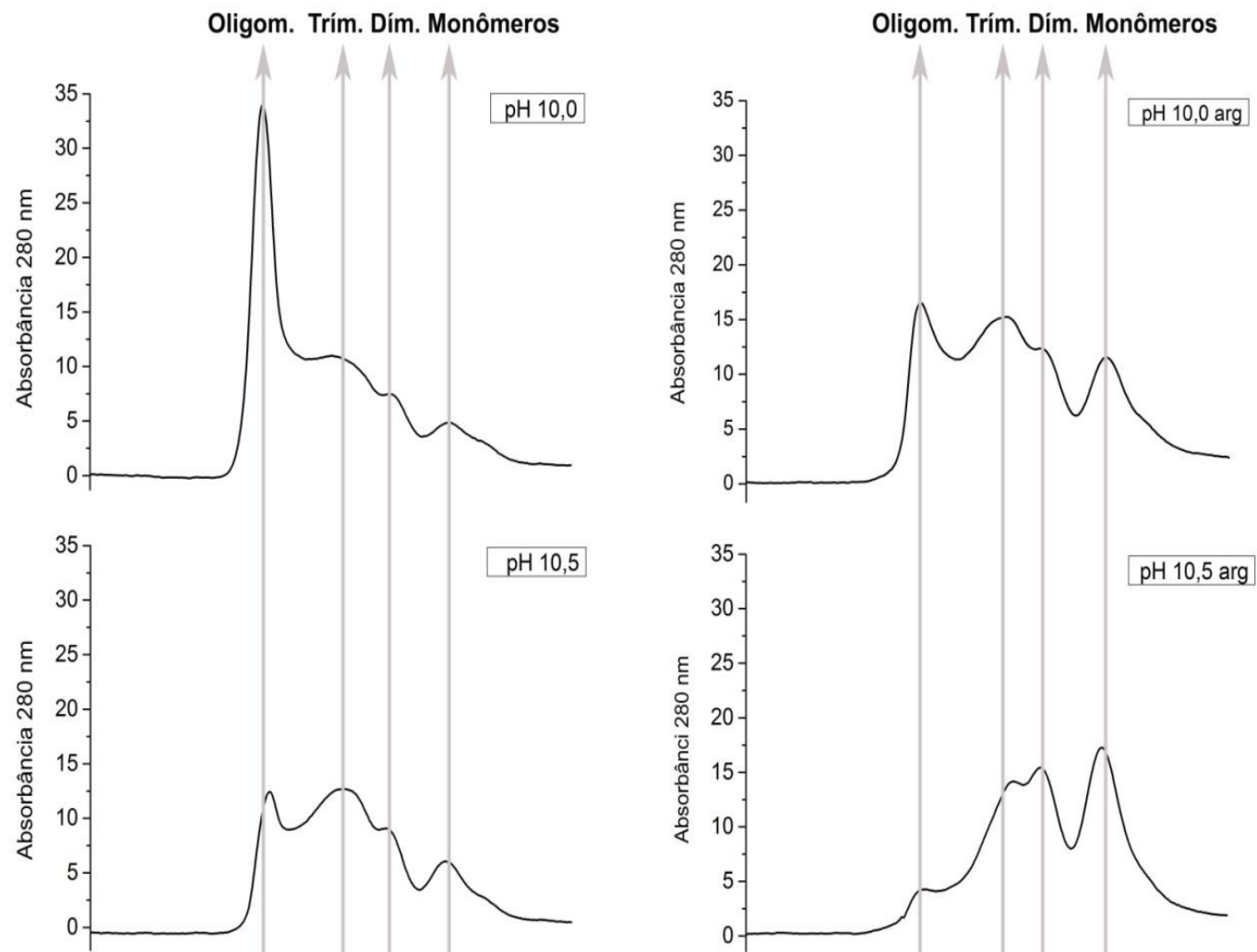

$\mathrm{pH} \mathrm{10,5}$
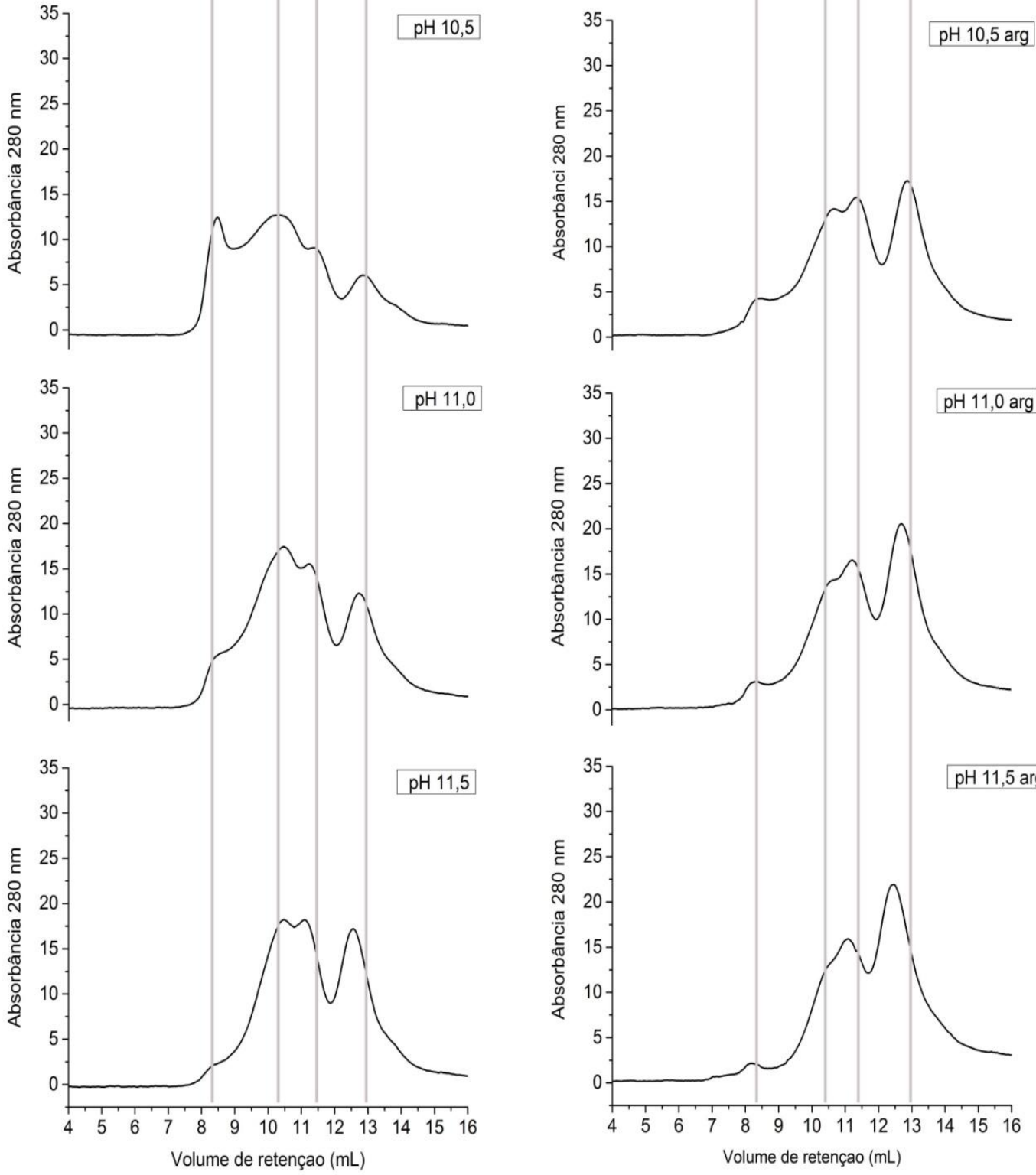

Figura 8. Cromatogramas em coluna de exclusão molecular de sobrenadantes de suspensões de $\mathrm{Cl}$ de NS1 de DENV submetidas à pressão de 2,4 kbar por $1 \mathrm{~h} 30$ min e $0,4 \mathrm{kbar}$ por $14 \mathrm{~h} 30 \mathrm{~min}$ e dialisadas contra Tris $50 \mathrm{~mm} \mathrm{pH} 8,5$, eluidas neste mesmo tampão. As suspensões foram submetidas à pressão em pH de 10 a 11,5 na presença de $0,4 \mathrm{M}$ de arginina ou na sua ausência. Foram aplicados $500 \mu \mathrm{l} \mathrm{em}$ coluna Superdex 200 10/300 (GE Biosciences). 
Em artigos publicados anteriormente o nosso grupo de pesquisa observou que a alta pressão (2,4 kbar) é capaz de solubilizar os agregados proteicos que formam os $\mathrm{Cl}$, e que o reenovelamento da proteína pode ocorrer durante incubação em pressões intermediárias (0,3 a 0,8 kbar). A incubação nestas condições aumenta o rendimento de reenovelamento, pelo fato de neste nível de pressão ocorrer certo grau de enovelamento, enquanto a reagregação é inibida (CHURA-CHAMBI et al., 2013; MALAVASI et al., 2011). A fim de verificarmos se a proteína NS1 solubilizada dos $\mathrm{Cl}$ em alta pressão (2,4 kbar) e em $\mathrm{pH}$ alcalino é capaz de ser reenovelada eficientemente em pressão atmosférica, ou se a incubação em diferentes tempos em pressão intermediária (0,4 kbar) pode ser útil para elevar o rendimento de refolding da NS1, foram testadas diferentes condições de descompressão. A compressão foi realizada em 2,4 kbar por 1h30min, mas a descompressão foi feita diretamente para pressão atmosférica (condição 1) ou foram feitas incubações em 0,4 kbar por 6h30min (condição 2) ou por 14h30min (condição 3) antes da descompressão completa. Podemos verificar nos géis de eletroforese da Figura 9A (amostras não reduzidas) que as bandas nas alturas correspondentes a $45 \mathrm{kDa}$ e $90 \mathrm{kDa}$ das amostras que foram incubadas na condição 2 (2,4 kbar por 1h30min e 0,4 kbar por 6h30min) são mais intensas do que as das amostras das outras condições, o que indica que foi obtida maior porcentagem de monômeros e dímeros nesta condição do que nas outras duas condições, em que se observa maior intensidade das bandas de maior massa molecular. Entretanto, na fotografia do SDS-PAGE da Figura 9B (amostras reduzidas) são observadas bandas de intensidade similar entre as amostras incubadas nas condições 1, 2 e 3 , o que indica que foi obtida concentração semelhante de proteína solúvel. 


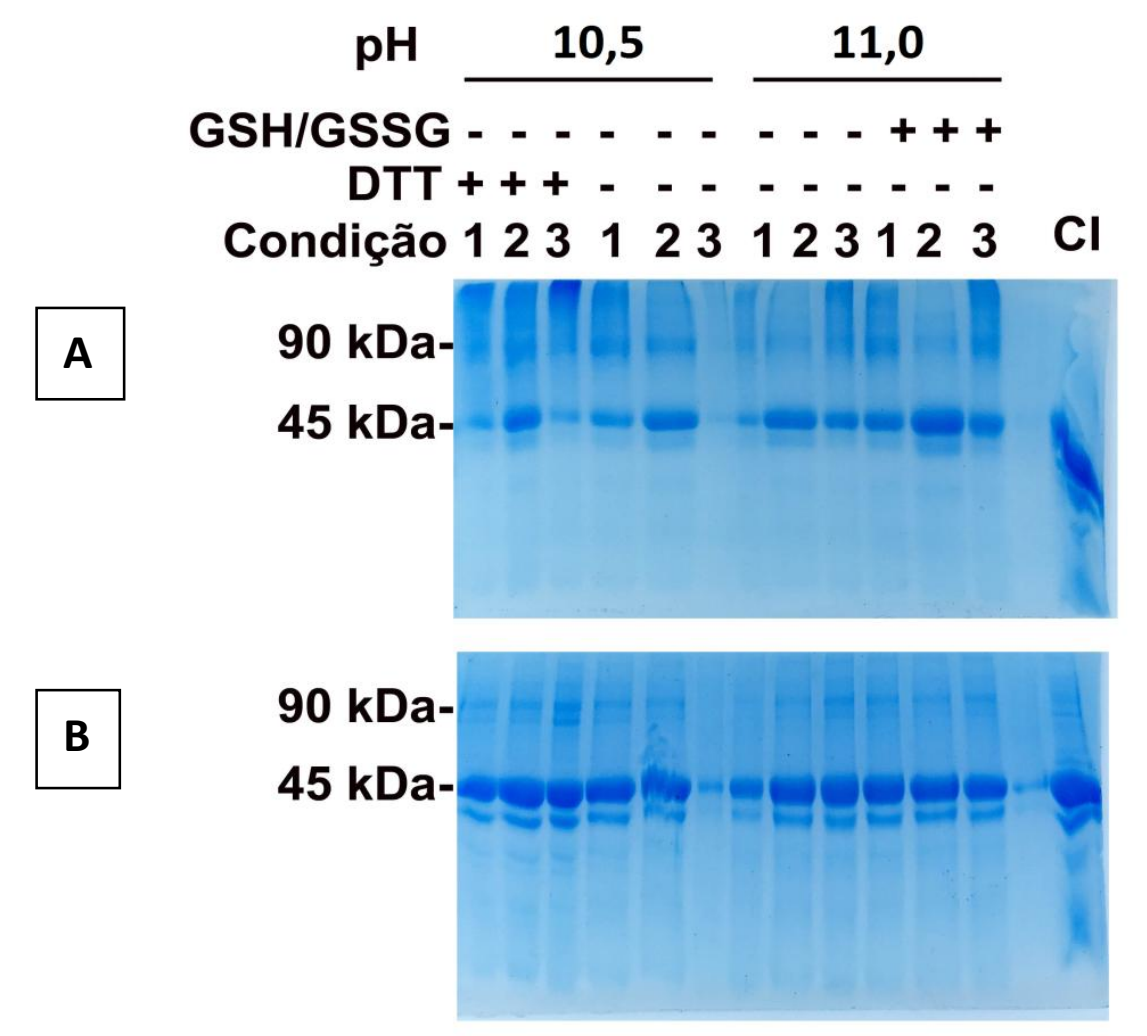

Figura 9. SDS-PAGE. Sobrenadantes de $\mathrm{Cl}$ de NS1 de DENV submetidos à pressão em pH 10,5 e 11,5 na presença de $0,4 \mathrm{M}$ de arg e DTT $(2 \mathrm{mM})$ e de $1 \mathrm{~mm}$ GSH e $0,1 \mathrm{~mm}$ de GSSG (conforme indicado na figura) e dialisadas, analisadas por SDS-PAGE. Condições: tempos de incubação e pressão: 1: 1h30min. em 2,4 Kbar; 2: 1h30min. em 2,4 kbar e 6h30min. em 0,4 kbar; 3: 1h30min. em 2,4 kbar e $14 \mathrm{~h} 30 \mathrm{~min}$. em 0,4 kbar. $\mathrm{Na}$ imagem $\mathrm{A}$ as amostras não foram reduzidas e na imagem $B$ foram reduzidas pela adição de DTT $100 \mathrm{mM}$. As amostras não foram fervidas, com exceção dos $\mathrm{Cl}$, que foram fervidos e reduzidos nos dois géis.

A fim de avaliarmos a reatividade de amostras de NS1 reenoveladas em diferentes pHs e presença ou ausência de arg e GSH e GSSH durante o processo de compressão, foram realizados testes de imunoabsorção de ELISA. Amostras de NS1 reenoveladas foram utilizadas para sensibilização das placas de 96 poços e foi analisada a capacidade de ligação de anticorpos IgG de pacientes infectados por DENV. Todas as amostras analisadas apresentaram altos títulos de anticorpos (acima de 2200) quando os soros positivos para dengue foram utilizados e títulos muito baixos quando soros de pacientes que não haviam sido infectados por este vírus foram utilizados (Figura 10). Aparentemente a presença de GSH/GSSG durante a compressão das amostras a partir do pH 9,5 melhora a ligação da proteína NS1 aos anticorpos específicos. Apesar de a amostra submetida a pressão em ph 9,0 apresentar ligação ligeiramente maior de 
anticorpos do que o as amostras comprimidas em $\mathrm{pH}$ mais alcalino, decidimos não utilizar o pH 9,0 para o refolding da NS1 em alta pressão nos experimentos subsequentes devido ao seu rendimento ser bem mais baixo do que o da proteína obtida pela compressão dos $\mathrm{Cl}$ em $\mathrm{pH}$ mais alcalino. Além disso, os anticorpos do soro de paciente positivo para dengue reconhecem epítopos conformacionais da proteína NS1 (linhas pretas), como comprovado pela queda dos valores de absorbância quando os soros foram incubados com a NS1 desnaturada por aquecimento (linhas vermelhas) (Figura 11).

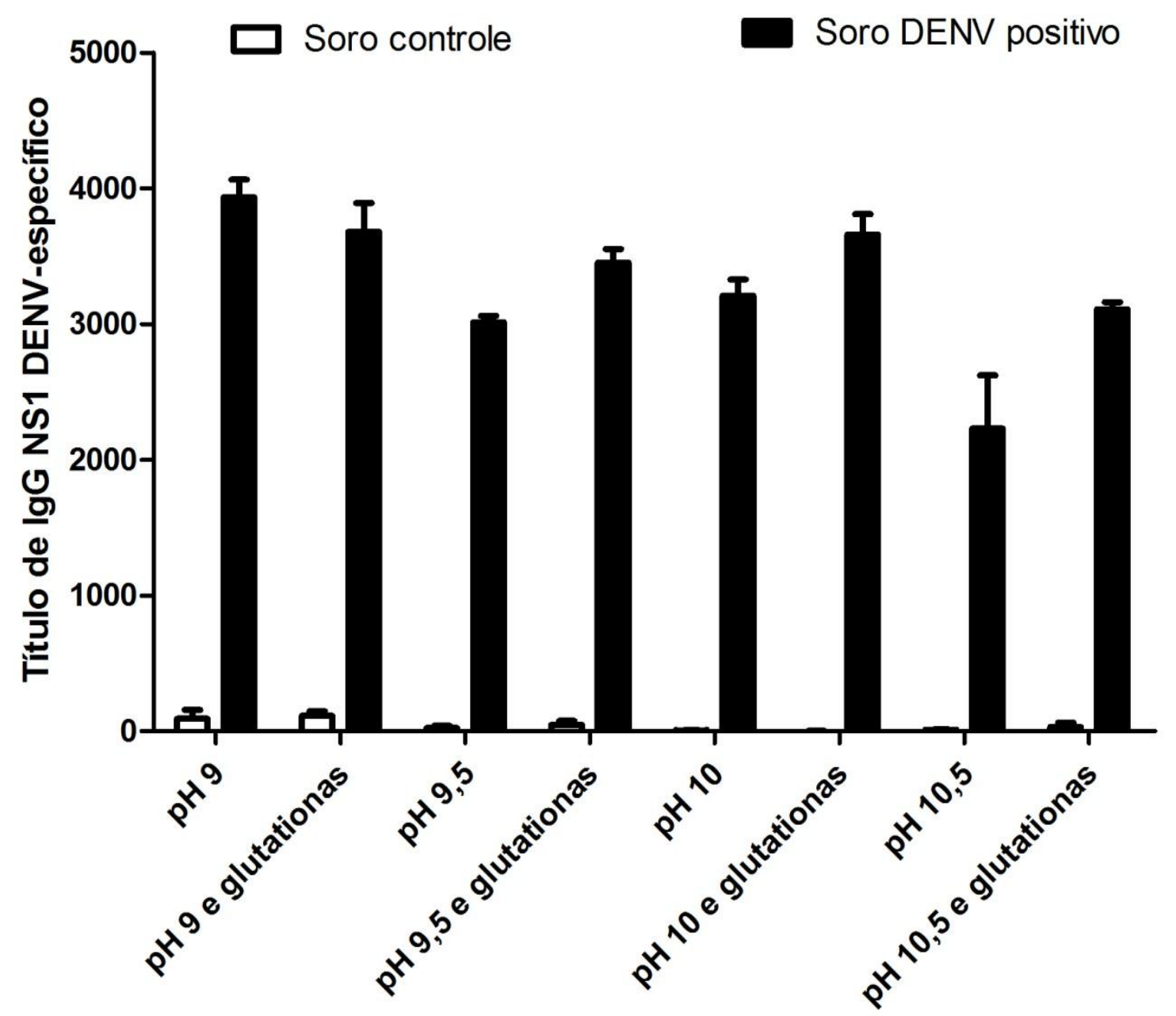

Figura 10. Avaliação da reatividade da proteína NS1 de DENV obtida em diferentes condições de

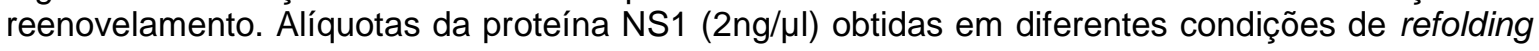
foram utilizadas como antígeno de fase sólida em ensaios de Elisa empregando soros controles obtidos de pacientes previamente infectados (barras pretas) ou não (barras brancas) com o DENV tipo 2. Os valores são expressos em média \pm erro dos títulos de anticorpos lgG antígeno específicos. A compressão dos $\mathrm{Cl}$ foi realizada em 2,4 kbar por 90 min e em 0,4 kbar por $6 \mathrm{~h} 30 \mathrm{~min}$ (condição 2). 
$\mathrm{pH} 9$

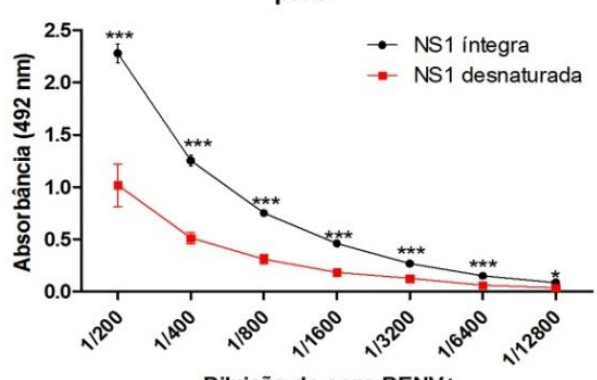

Diluição do soro DENV+

$\mathrm{pH} 9,5$

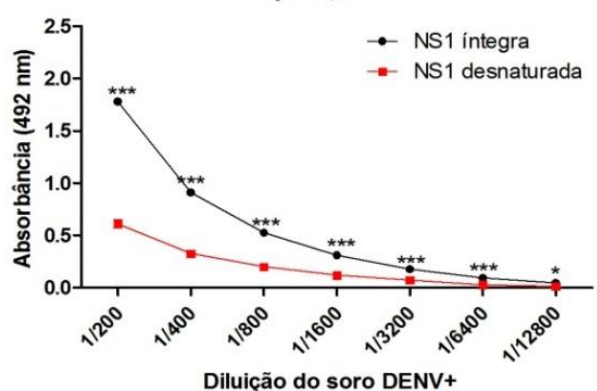

pH 10

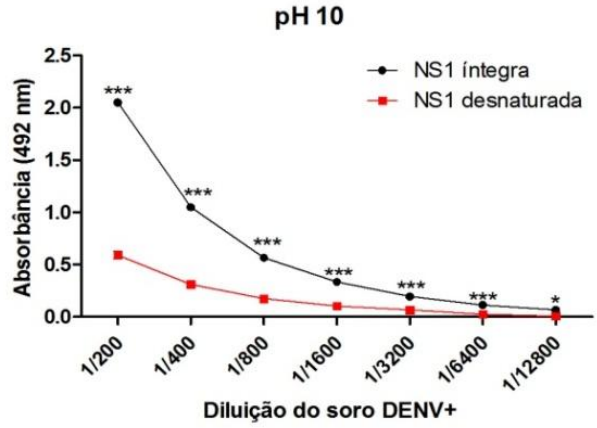

$\mathrm{pH} 10,5$

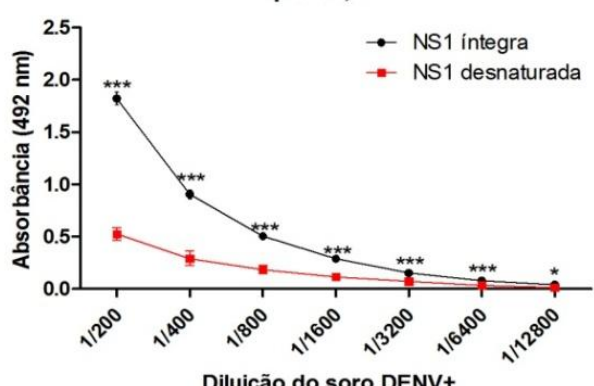

$\mathrm{pH} 9$ e glut

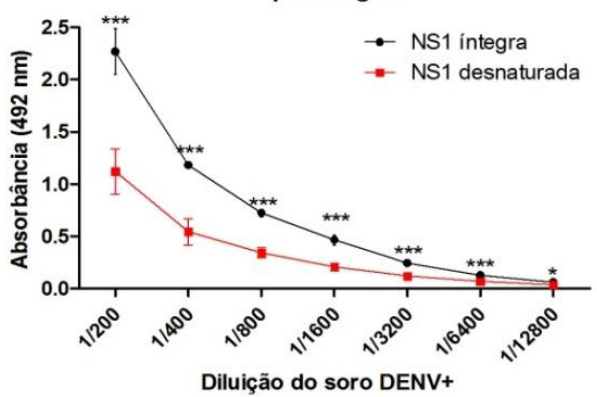

$\mathrm{pH} 9,5$ e glut

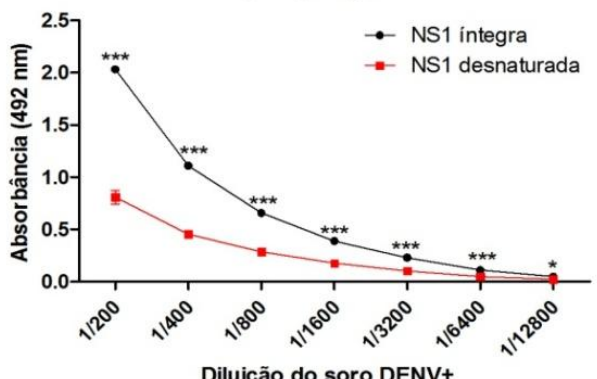

$\mathrm{pH} 10$ e glut

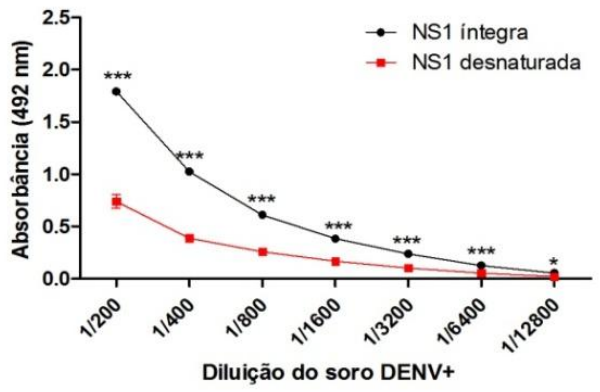

pH 10,5 e glut

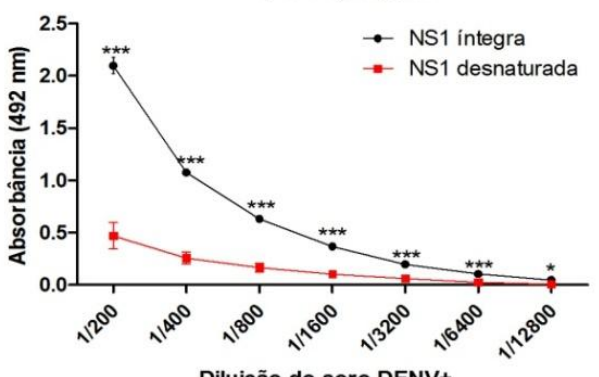

Diluição do soro DENV+

Figura 11. Avaliação da preservação de epítopos conformacionais na proteína NS1 de DENV (2ng/ $\mathrm{ll}$ ) obtidas em diferentes condições de reenovelamento. Amostras da proteína NS1 de DENV, submetidas ou não previamente à desnaturação (aquecimento a $100^{\circ} \mathrm{C}$ por 10 min. seguido de choque térmico à $0{ }^{\circ} \mathrm{C}$ ), foram analisadas por ELISA quanto a sua reatividade com soro de paciente previamente infectado com o DENV. Os valores obtidos são expressos em média \pm erro da absorbância obtida no ensaio. ${ }^{*} p<0,05 ;{ }^{* *} p<0,01 ;{ }^{* * *} p<0,001$. (Two-way ANOVA com teste de Bonferroni). A compressão dos $\mathrm{Cl}$ foi realizada em 2,4 kbar por $1 \mathrm{~h} 30 \mathrm{~min}$ e em 0,4 kbar 6h30min. 
Com o objetivo de otimizar o protocolo em desenvolvimento, amostras de $\mathrm{Cl}$ foram submetidas à compressão (2,4 kbar por 1h30min e 0,4 kbar por 6 h30min) em pH 10,5 contendo ou não arg (0,4M), glutationas GSH e GSSG $(1,0$ e $0,1 \mathrm{mM}$, respectivamente) e DTT $(2 \mathrm{mM})$.

A reatividade de anticorpos para a NS1 reenovelada em $\mathrm{pH} 10,5$ e na presença ou ausência de outros reagentes são mostrados na Figura 12, em comparação com a NS1 reenovelada no Laboratório de Desenvolvimento de Vacinas (LDV). No LDV o reenovelamento é obtido utilizando-se um protocolo no qual os $\mathrm{Cl}$ são solubilizados em tampão contendo 8M de ureia, e a fração solúvel é diluída 100 vezes por diluição pulsada com auxilio de bomba peristáltica sob agitação. Após esta etapa a amostra é centrifugada e filtrada em membrana de 0,22 $\mu \mathrm{m}$ (Millipore), sendo posteriormente realizada a purificação em coluna de afinidade por Histidina de $5 \mathrm{ml}$. Após aplicação da amostra, é realizada a lavagem da mesma com 10 volumes de coluna de tampão, e em seguida a proteína é eluída pela aplicação de gradiente linear (0 a $1 \mathrm{M}$ ) de Imidazol em tampão com pH 8,2. A amostra é então mantida em tampão contendo 0,1M Tris; 0,25 M NaCl; $1 \mathrm{M}$ Imidazol; 20\% glicerol; pH 8.2. O rendimento obtido por este processo é de aproximadamente $3,5 \mathrm{mg} / \mathrm{L}$ de cultura bacteriana.

A maior reatividade de anticorpos anti-NS1 foi obtida na condição em que a compressão dos $\mathrm{Cl}$ foi realizada na presença de arg e o par de glutationas. Esta também foi a condição em que obtivemos maior concentração de NS1 $(0,424$ $\mathrm{mg} / \mathrm{mL}$ e $104 \mathrm{mg} / \mathrm{L}$ de cultura bacteriana - tabela 1), o que por si só já a qualifica como a melhor condição de renaturação. A reatividade dos anticorpos de indivíduo soro-negativo para DENV foram menores para as proteínas reenoveladas utilizando alta pressão do que para a NS1 do LDV. Além disso, esta condição também possui uma boa ligação à epitopos conformacionais, conforme mostrado na Figura 13.

Uma outra questão que gostaríamos de responder é se o aumento da concentração de NS1 imobilizado é capaz de aumentar também a ligação de anticorpos no ensaio de ELISA. Para responder está pergunta escolhemos uma condição que foi a compressão dos $\mathrm{Cl}$ em $\mathrm{pH} 10,5$ e presença do par de glutationas. Duas concentrações: a concentração normal $(2 \mathrm{ng} / \mu \mathrm{l})$ e o dobro desta concentração (4 ng/ $\mu$ l) de NS1 reenovelada nesta condição foram utilizadas para 
sensibilização da placa no ensaio de ELISA. Observamos que a maior concentração de NS1 promoveu a obtenção de maior absorbância (a 492 nm), o que demonstra maior reatividade com relação à mesma amostra em concentração de $2 \mathrm{ng} / \mu \mathrm{l}$ (Figuras 12 e 13). Concluimos com este teste que mesmo que em condições de igualdade de concentração a nossa proteina não alcançasse a reatividade obtida pela proteina LDV, poderiamos consegui-la através do aumento da concentração, já que o nosso rendimento é muito mais elevado do que o obtido pelo protocolo de refolding da NS1 no LDV (Tabela 1). Além disso, a nossa amostra apresentou reatividade baixa ao soro negativo e ligeiramente menor do que o observado para a proteína do LDV (Figura 12). 


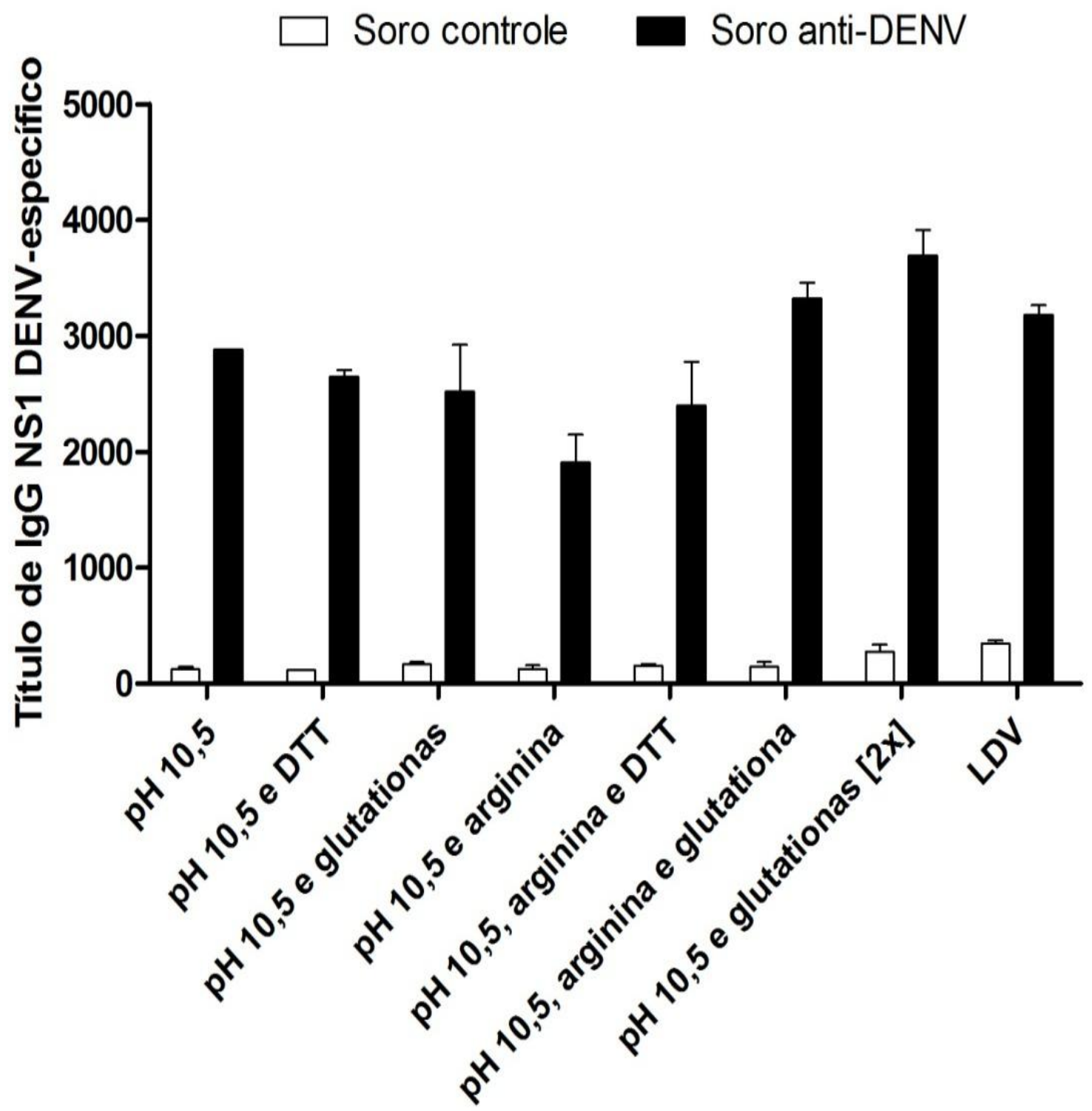

Figura 12. Avaliação da reatividade da proteína NS1 de dengue obtida em diferentes condições de reenovelamento. Alíquotas da proteína NS1 ( $\mathrm{ng} / \mu \mathrm{l})$ obtidas nas diferentes condições de refolding descritas na imagem foram utilizadas como antígeno de fase sólida em ensaios de ELISA empregando soros controles obtidos de pacientes previamente infectados (barras pretas) ou não (barras brancas) com o vírus da dengue tipo 2. Os valores são expressos em média \pm erro dos títulos de anticorpos IgG antígeno específicos. A compressão dos $\mathrm{Cl}$ foi realizada em 2,4 kbar por 1 h30min e em 0,4 kbar por 6h30min. LDV: NS1 obtida do mesmo clone utilizado no nosso trabalho e reenovelada no Laboratório de Desenvolvimento Vacinal. 
pH 10,5

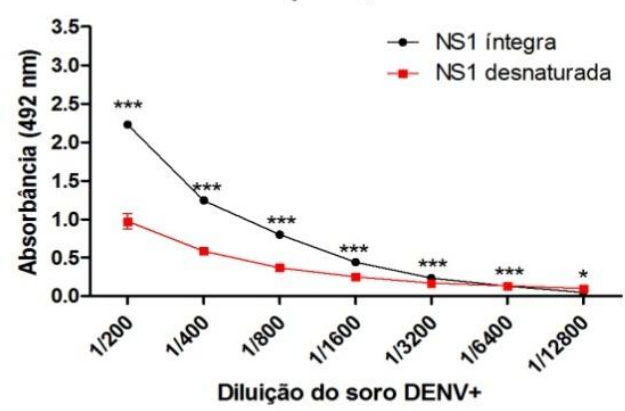

pH 10,5 e DTT

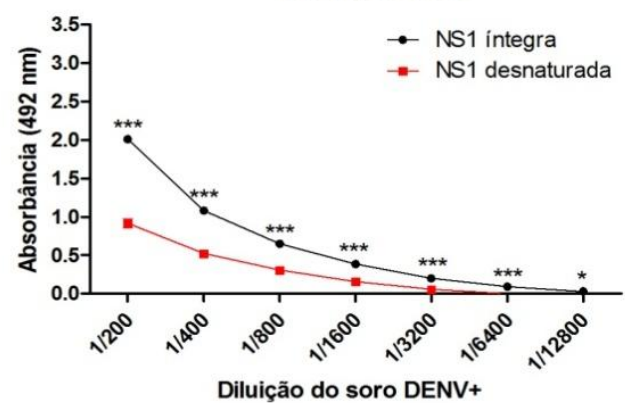

$\mathrm{pH} 10,5$ e glut

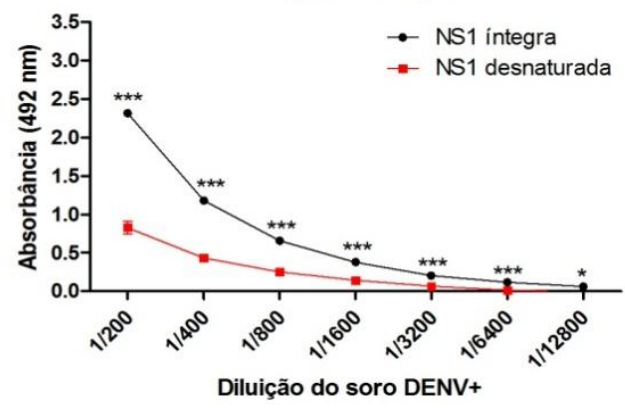

$\mathrm{pH} 10,5$ e glut $[2 \mathrm{x}]$

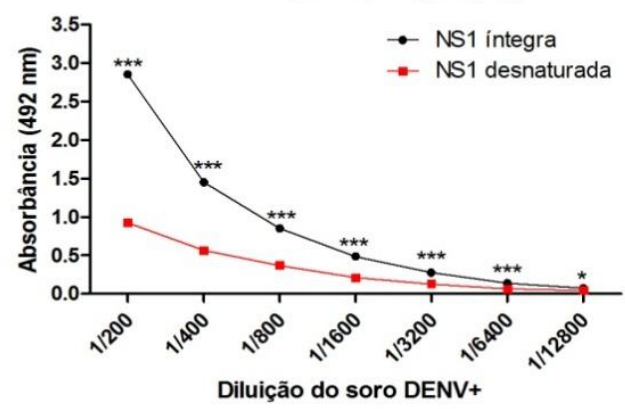

$\mathrm{pH} 10,5$ e arg

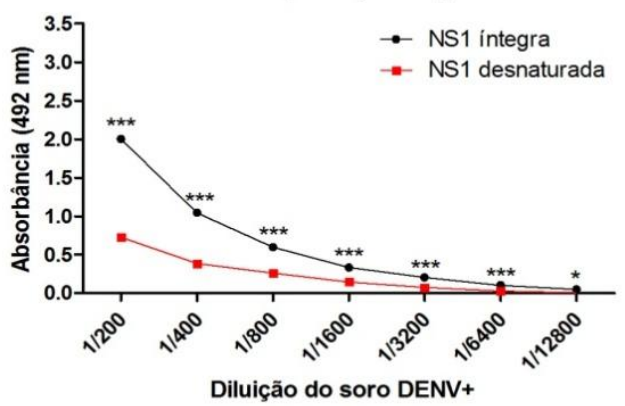

pH 10,5 - arg - DTT

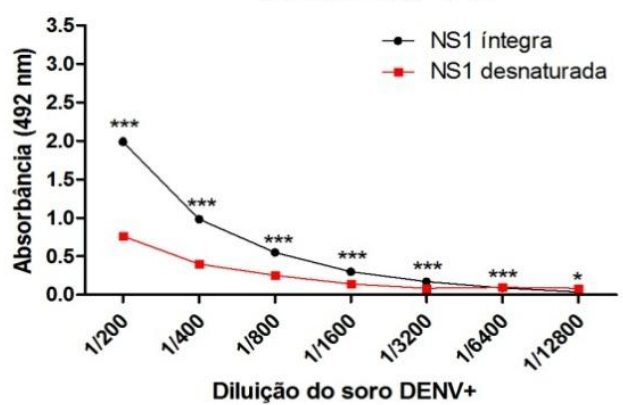

pH 10,5 - arg - glut

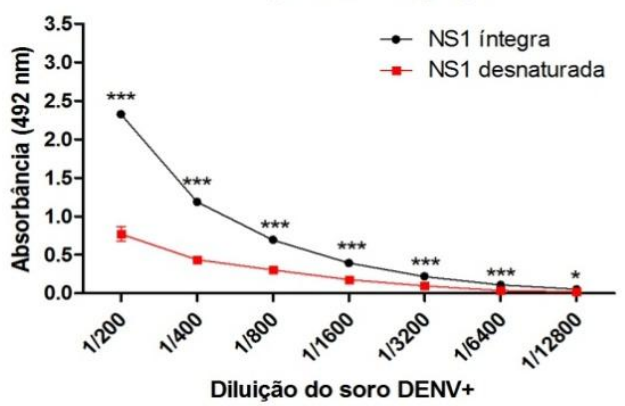

LDV

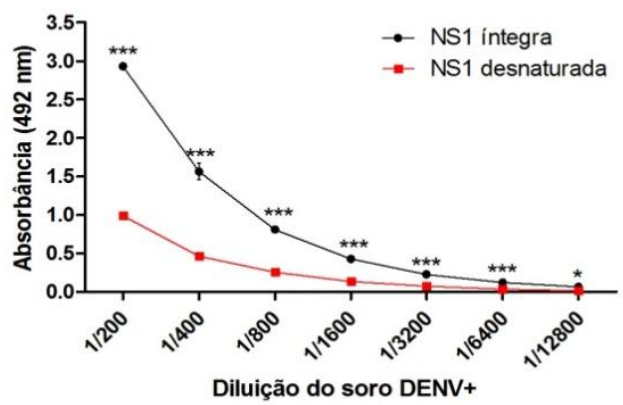

Figura 13. Avaliação da preservação de epítopos conformacionais da proteína NS1 de DENV obtida em diferentes condições de reenovelamento. Amostras da proteína NS1 de DENV $(2 \mathrm{ng} / \mu \mathrm{l})$, submetidas ou não previamente à desnaturação (aquecimento a $100^{\circ} \mathrm{C}$ por $10 \mathrm{~min}$. seguido de choque térmico à $0^{\circ} \mathrm{C}$ ), foram analisadas por ELISA quanto a sua reatividade com soro de paciente previamente infectado com o DENV. Os valores obtidos são expressos em média \pm erro da absorbância obtida no ensaio. ${ }^{*} p<0,05 ;{ }^{* *} p<0,01 ;{ }^{* * *} p<0,001$. (Two-way ANOVA com teste de Bonferroni). A compressão dos $\mathrm{Cl}$ foi realizada em 2,4 kbar por $1 \mathrm{~h} 30 \mathrm{~min}$ e em 0,4 kbar 6h30min. 
Tendo sido definida a condição de compressão com a qual obtivemos um alto rendimento de obtenção de NS1 que manteve suas propriedades antigênicas, que foi a compressão dos $\mathrm{Cl}$ em pH 10,5, presença de $\arg (0,4 \mathrm{M}) \mathrm{e}$ glutationas GSH e GSSG (1,0 mM e 0,1 mM), gostaríamos de saber se existe alteração de reatividade da NS1 reenovelada utilizando diferentes protocolos de compressão/descompressão. Foram utilizadas as seguintes condições de compressão/descompressão dos $\mathrm{Cl}$ :

Condição 1: 2,4 kbar por 1h30min;

Condição 2: 2,4 kbar por 1h30min e 0,4 kbar por 6h30min;

Condição 3: 2,4 kbar por 1h30min e 0,4 kbar por 14h30min.

Neste ensaio obtivemos concentrações similares de NS1 para as 3 condições: $0,489 \mathrm{mg} / \mathrm{mL}(119,8 \mathrm{mg} / \mathrm{L}$ de cultura) para a condição $1 ; 0,436 \mathrm{mg} / \mathrm{mL}$ (106,8 mg/L de cultura) para a condição 2 e $0,460 \mathrm{mg} / \mathrm{mL}(112,7 \mathrm{mg} / \mathrm{L}$ de cultura) para a condição 3 .

A condição 2 de compressão/descompressão foi a condição com a qual foi obtido maior reconhecimento de anticorpos com boa ligação aos epítopos conformacionais (Figuras 14 e 15) e foi a condição escolhida.

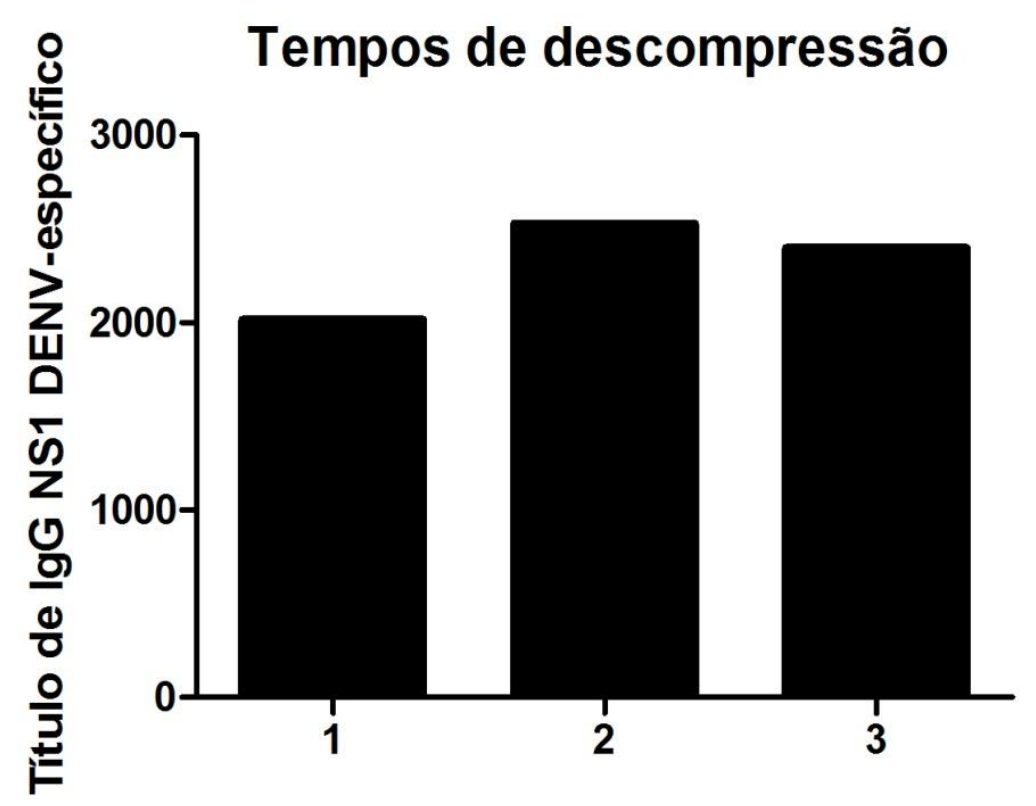

Figura 14. Avaliação da reatividade da proteína NS1 de DENV obtida em diferentes condições de tempo de descompressão. Alíquotas da proteína NS1 (2ng/ $\mu$ l) obtidas em diferentes condições de tempo de descompressão foram utilizadas como antígeno de fase sólida em ensaios de ELISA empregando soros controles obtidos de pacientes previamente infectados (barras pretas) ou não (barras brancas) com o vírus da dengue tipo 2. Os valores são expressos em média \pm erro dos títulos de anticorpos lgG antígeno específicos. A compressão/descompressão dos $\mathrm{Cl}$ foi realizada nas condições 1, 2 e 3 descritas no texto. 
1

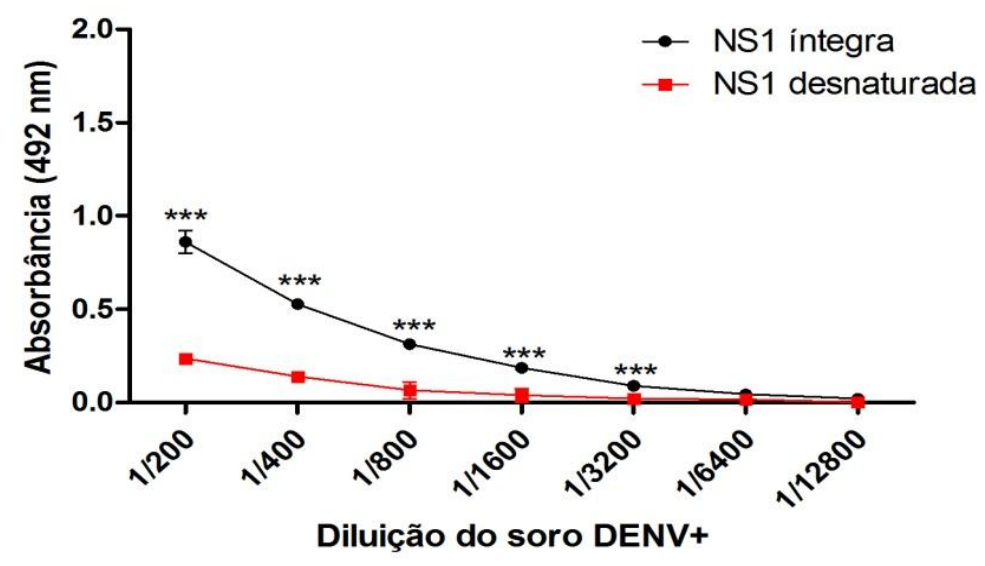

2

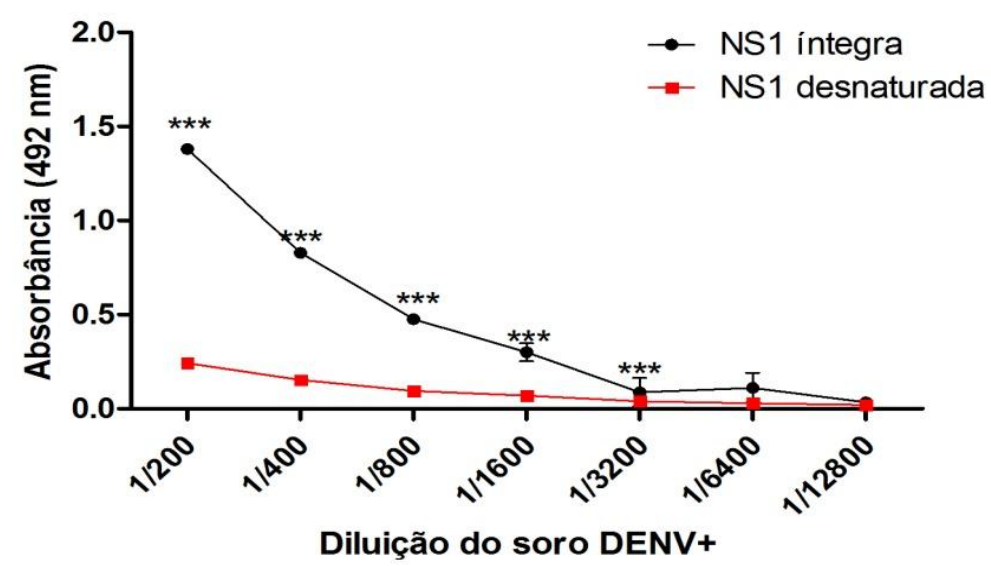

3

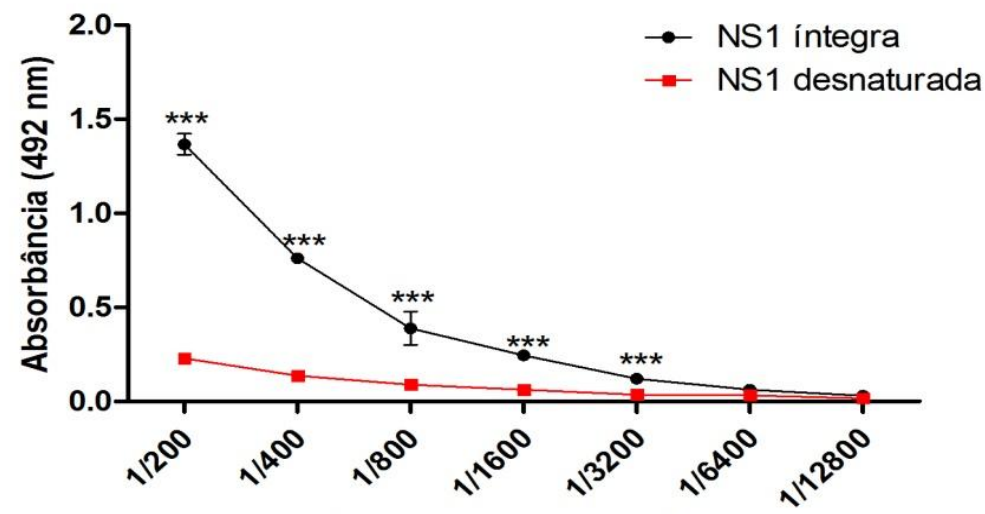

Diluição do soro DENV+

Figura 15. Avaliação da preservação de epítopos conformacionais da proteína NS1 de DENV obtida em diferentes condições de tempo de descompressão. Amostras da proteína NS1 de DENV, submetidas ou não previamente à desnaturação (aquecimento a $100^{\circ} \mathrm{C}$ por $10 \mathrm{~min}$. seguido de choque térmico à $0^{\circ} \mathrm{C}$ ), foram analisadas por ELISA quanto a sua reatividade com soro de paciente previamente infectado com o DENV. Os valores obtidos são expressos em média \pm erro da absorbância obtida no ensaio. ${ }^{*} p<0,05 ;{ }^{* *} p<0,01 ;{ }^{* *} p<0,001$. (Two-way ANOVA com teste de Bonferroni). A compressão dos $\mathrm{Cl}$ foi realizada nas condições 1,2 e 3 descritas no texto. 
Considerando que o nível de contaminação dos Cl de NS1 por proteínas de E. coli é baixo, conforme se pode observar no SDS-PAGE da Figura 16, o método que utilizamos para a quantificação de NS1 foi a determinação de absorbância a $280 \mathrm{~nm}$, utilizando o valor de Abs $0,1 \%=2,070$. O rendimento de refolding de NS1 de DENV foi baixo quando a suspensão foi submetida à pressão em pH 9,0 (dados não mostrados). A quantificação de NS1 (em mg por mL) e rendimento de NS1 reenovelada por litro de cultura bacteriana de dois experimentos realizados separadamente são apresentados nas Tabelas 1 e 2. $\mathrm{Na}$ Tabela 1 podemos observar que foram obtidos $0,42 \mathrm{mg}$ de $\mathrm{NS} 1 / \mathrm{mL}$, com rendimento de 103,9 mg/L de cultura quando a suspensão de Cl de NS1 foi submetida à alta pressão (2,4 kbar por 90 min e 0,4 kbar por 6h30min) em pH 10,5 e na presença de arginina e glutationas.

Tabela 1. Quantificação de NS1 de amostras reenoveladas pela aplicação de pressão (2,4 kbar por 90 min e 0,4 kbar por 6h30min) por A280 nm.

\begin{tabular}{lll}
\hline Condições de Refolding & $\begin{array}{l}\text { Quantificação } \\
(\mathrm{mg} / \mathrm{mL} \mathrm{NS1})\end{array}$ & $\begin{array}{l}\text { Rendimento de NS1 } \\
\text { reenovelada/litro de } \\
\text { cultura bacteriana }\end{array}$ \\
\hline $\mathrm{pH} \mathrm{10,5}$ & $0,283 \mathrm{mg} / \mathrm{ml}$ & $69,3 \mathrm{mg} / \mathrm{L}$ \\
\hline $\mathrm{pH} \mathrm{10,5} \mathrm{-} \mathrm{DTT} \mathrm{2mM}$ & $0,365 \mathrm{mg} / \mathrm{ml}$ & $89,4 \mathrm{mg} / \mathrm{L}$ \\
\hline $\mathrm{pH} \mathrm{10,5} \mathrm{-} \mathrm{GSH} \mathrm{1mM} \mathrm{-} \mathrm{GSSG} \mathrm{0,1} \mathrm{mM}$ & $0,376 \mathrm{mg} / \mathrm{ml}$ & $92,1 \mathrm{mg} / \mathrm{L}$ \\
\hline $\mathrm{pH} \mathrm{10,5} \mathrm{-} \mathrm{arg} \mathrm{0,4M}$ & $0,341 \mathrm{mg} / \mathrm{ml}$ & $83,6 \mathrm{mg} / \mathrm{L}$ \\
\hline $\mathrm{pH} \mathrm{10,5} \mathrm{-} \mathrm{arg} \mathrm{0,4M} \mathrm{-} \mathrm{DTT} \mathrm{2mM}$ & $0,386 \mathrm{mg} / \mathrm{ml}$ & $94,6 \mathrm{mg} / \mathrm{L}$ \\
\hline $\mathrm{pH} \mathrm{10,5} \mathrm{-} \mathrm{arg} \mathrm{0,4M} \mathrm{-} \mathrm{GSH} \mathrm{1mM} \mathrm{-} 0,424 \mathrm{mg} / \mathrm{ml}$ & $103,9 \mathrm{mg} / \mathrm{L}$ \\
GSSG 0,1 mM & & \\
\hline LDV: NS1 reenovelada no Laboratório & $0,083 \mathrm{mg} / \mathrm{ml}$ & $3,5 \mathrm{mg} / \mathrm{L}{ }^{*}$ \\
de Desenvolvimento Vacinal & & \\
\hline *(AMORIM et al., 2010). & & \\
\hline
\end{tabular}


Tabela 2. Quantificação de NS1 de amostras reenoveladas pela aplicação de pressão (2,4 kbar por 90 min e 0,4 kbar por $6 \mathrm{~h} 30 \mathrm{~min}$ ) por A280 $\mathrm{nm}$.

\begin{tabular}{|c|c|c|}
\hline Condições de Refolding & $\begin{array}{l}\text { Quantificação } \\
\text { (mg/mL NS1) }\end{array}$ & $\begin{array}{l}\text { Rendimento de NS1 } \\
\text { reenovelada/litro de cultura } \\
\text { bacteriana }\end{array}$ \\
\hline $\mathrm{pH} 10,5$ - DTT 2mM & $0,600 \mathrm{mg} / \mathrm{mL}$ & $134,5 \mathrm{mg} / \mathrm{L}$ \\
\hline $\mathrm{pH} 10,5-\arg 0,4 \mathrm{M}$ & $0,488 \mathrm{mg} / \mathrm{mL}$ & $109,4 \mathrm{mg} / \mathrm{L}$ \\
\hline $\mathrm{pH} 11,0-\arg 0,4 \mathrm{M}$ & $0,434 \mathrm{mg} / \mathrm{mL}$ & $97,3 \mathrm{mg} / \mathrm{L}$ \\
\hline $\begin{array}{l}\mathrm{pH} 11,0-\arg 0,4 \mathrm{M}- \\
\mathrm{GSH} 1 \mathrm{mM}-\mathrm{GSSG} \\
0,1 \mathrm{mM}\end{array}$ & $0,515 \mathrm{mg} / \mathrm{mL}$ & $115,5 \mathrm{mg} / \mathrm{L}$ \\
\hline
\end{tabular}

Podemos observar no gel de SDS-PAGE da Figura 16 que a intensidade das bandas referente à NS1 das colunas 1 a 4 na linha de amostras de sobrenadantes de $\mathrm{Cl}$ submetidas à pressão em diferentes condições é similar à banda 5 , referente à suspensão de $\mathrm{Cl}$ no mesmo volume, o que demonstra 0 alto rendimento de obtenção de proteína solúvel a partir dos agregados proteicos. Os rendimentos calculados utilizando o programa Image $J$ para comparação entre as quantidade de NS1 nas amostras reenoveladas (colunas 1 a 4 na linha amostras) e na suspensão original (coluna 5 na linha amostras) foram entre $80 \%$ e $95 \%$. O rendimento de refolding de NS1 pela aplicação de pressão (2,4 kbar por 90 min e 0,4 kbar por 6 h30min) aos $\mathrm{Cl}$ em pH 10,5 + arg e glutationas foi de $90 \%$ em relação à quantidade de proteína presente nos $\mathrm{Cl}$ (Figura 16) e de 0,488 $\mathrm{mg} / \mathrm{mL}$ e $110 \mathrm{mg} / \mathrm{L}$ de cultura bacteriana pela análise por $A_{280} \mathrm{~nm}$. A concentração de NS1 obtida pela quantificação por comparação à curva de BSA em SDS-PAGE para esta amostra é quase $50 \%$ maior: de $0,726 \mathrm{mg} / \mathrm{mL}$ e $163 \mathrm{mg} / \mathrm{L}$ de cultura (Figura 16). Ainda na mesma figura (16) podemos verificar que a proteína se apresenta praticamente pura.

Se considerarmos a quantificação baseada em $A_{280 \mathrm{~nm}}(104 \mathrm{mg} /$ litro de cultura) e o cromatograma obtido por cromatografia de exclusão molecular da amostra reenovelada em pH 10,5 + arg (Figura 8) obtemos os seguintes valores: $5,8 \%$ (6,0 mg/litro de cultura) da NS1 reenovelada nessa condição se encontra na forma de oligômero, 29,8\% (31,0 mg/litro de cultura) na forma trimérica, 22,9\% 
(23,8 $\mathrm{mg} /$ litro de cultura) na forma dimérica e 41,5\% (43,2 mg/litro de cultura) da NS1 se encontra na forma monomérica. Acreditamos que os valores devem ser semelhantes entre as amostras reenoveladas na presença de arg e as reenoveladas na presença de arg e glutationas, devido ao fato de as bandas se apresentarem similares em SDS-PAGE (dados não mostrados).

\section{Amostras $\quad 12344 \quad 5$ \\ BSA 1223456}

Figura 16. Curva de BSA e amostras de NS1 de DENV reenoveladas em pH 10,5 e 11,0 analisadas por SDS-PAGE. Colunas 1 a 6 da linha "BSA": BSA nas concentrações de $1 \mathrm{mg} / \mathrm{mL}, 0,5$ $\mathrm{mg} / \mathrm{mL}, 0,25 \mathrm{mg} / \mathrm{mL}, 0,125 \mathrm{mg} / \mathrm{mL}, 0,062 \mathrm{mg} / \mathrm{mL}$ e $0,031 \mathrm{mg} / \mathrm{mL}$. Linha "amostras": coluna 1: NS1 reenovelada em pH 10,5 com $2 \mathrm{mM}$ DTT, coluna 2: NS1 reenovelada em $\mathrm{pH} 10.5 \mathrm{com} 0,4 \mathrm{M}$ de arg, coluna 3: NS1 reenovelada em pH 11 com 0,4M de arg, coluna 4: NS1 reenovelada em $\mathrm{pH} 11$ com 0,4M de arg e $1 \mathrm{mM}$ de GSH e 0,1mM de GSSG; Coluna 5: suspensão de CI. Todas as amostras foram reenoveladas na condição 2 de compressão/descompressão. Todas as amostras foram reduzidas com $100 \mathrm{mM}$ de DTT e fervidas. 


\subsection{NS1 de ZIKV}

Com a finalidade de determinarmos se a associação de alta pressão e $\mathrm{pH}$ alcalino, presença de $\mathrm{GdnHCl}$ ou arg são capazes de promover a solubilização eficiente dos $\mathrm{Cl}$ de NS1 de ZIKV com baixa desnaturação da proteína nos agregados, suspensões de $\mathrm{Cl}$ de NS1 de ZIKV foram mantidas em pressão atmosférica (1bar) ou submetidas à pressão de 2,4 kbar por 1h30min minutos e de 0,4 kbar por 14h30min, em pH de 7 a 12, 0 a $3 \mathrm{M}$ de $\mathrm{GdnHCl}(\mathrm{em} \mathrm{pH}$ 8,5) ou 0 a $0,6 \mathrm{M}$ de $\arg (\mathrm{em} \mathrm{pH} 10,5)$. Os gráficos de EL de uma suspensão de $\mathrm{Cl}$ da proteína recombinante NS1 de ZIKV em diferentes concentrações de GdnHCl submetida à pressão de 2,4 kbar por $1 \mathrm{~h} 30$ min e 0,4 kbar por 14h30min em comparação com a mesma suspensão que foi mantida em 1 bar por $16 \mathrm{~h}$ são mostrados na Figura 17A. A queda nos valores de EL, que indica solubilização dos agregados, foi mais evidente para as suspensões de $\mathrm{Cl}$ submetidas à alta pressão do que aquelas mantidas em 1 bar. A presença de 1,0 M de $\mathrm{GdnHCl}$ foi eficiente para a solubilização dos $\mathrm{Cl}$ em suspensões submetidas à pressão em $\mathrm{pH}$ 8,5. Na curva de pH (Figura 17B), pode-se observar que a queda nos valores de EL, que indica solubilização dos agregados, foi mais evidente a partir do $\mathrm{pH} 10,0$ para as suspensões de $\mathrm{Cl}$ submetidas à pressão. A curva de arg foi feita em $\mathrm{pH}$ 10,5 e por isso a solubilização em alta pressão é eficiente mesmo na ausência de arg, mas a presença deste aminoácido, mesmo em concentração baixa $(0,1 \mathrm{M})$ auxiliou ainda mais a solubilização dos $\mathrm{Cl}$ submetidos à alta pressão (Figura 17C). 
A

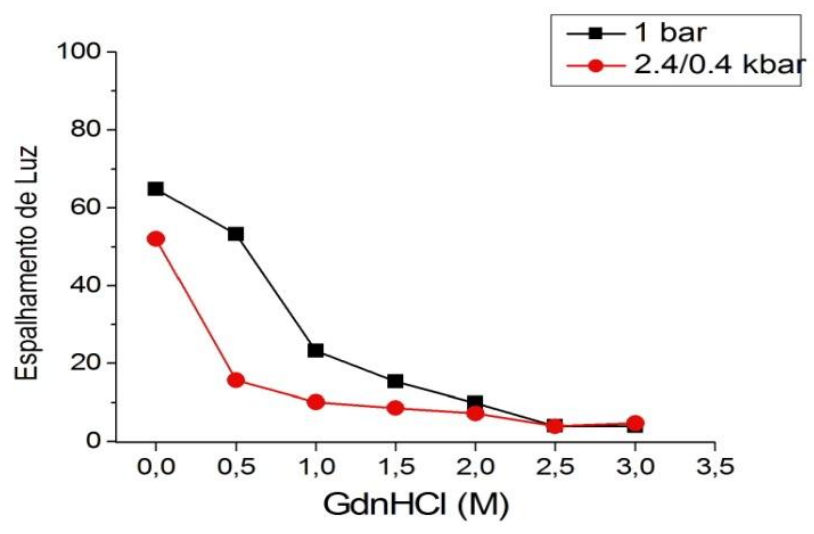

B

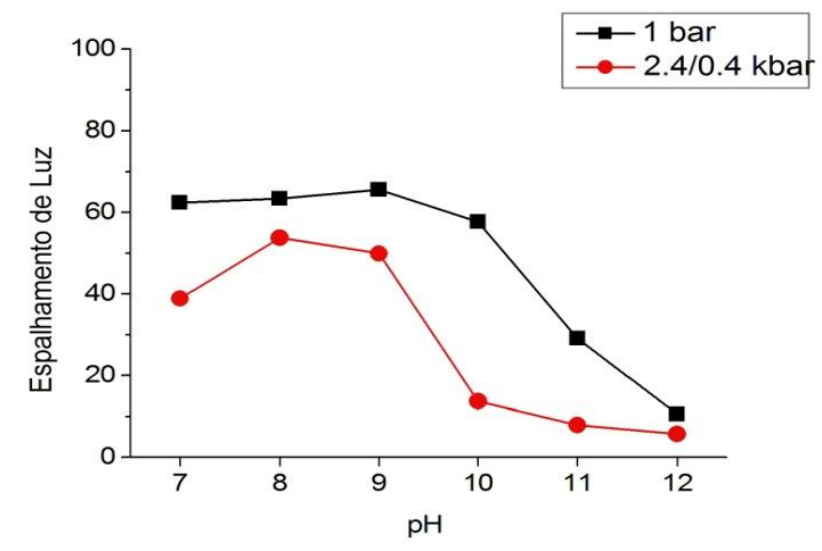

C

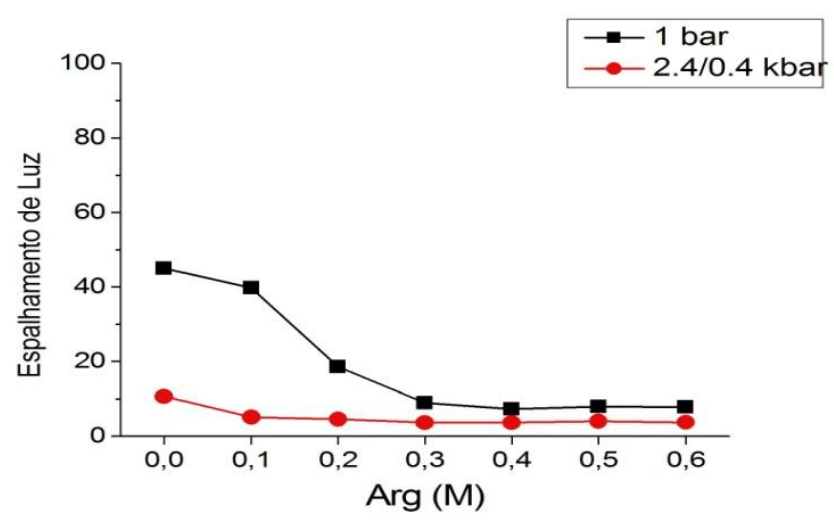

Figura 17. Efeito da alta pressão sobre suspensões de CI de NS1 de ZIKV. Gráficos de EL da suspensão de $\mathrm{Cl}$ submetidos ou não à alta pressão $(2,4 \mathrm{kbar} / 0,4 \mathrm{kbar})$ e incubadas por $16 \mathrm{~h}$. As medidas foram realizadas em espectrofluorímetro e utilizou-se a excitação de $320 \mathrm{~nm}$ e a emissão foi determinada entre 315 e $325 \mathrm{~nm}$. O valor de EL obtido para a suspensão em pH 8,0 e leitura em tempo zero em 1 bar foi considerado como $100 \%$. 
Na Figura 18 pode-se observar os gráficos de $\lambda$ máximo dos espectros de fluorescência intrínseca do triptofano de amostras de NS1 de ZIKV submetidos à alta pressão (2,4 kbar por 1h30min e 0,4 kbar por 14h30min) em comparação com as mesmas amostras mantidas em pressão atmosférica. Um pico máximo de fluorescência ( $\lambda$ máximo) de $342,2 \mathrm{~nm}$ foi observado para a suspensão de $\mathrm{Cl}$ de NS1 incubados em pH 7,0 e pressão atmosférica (Figura 18B). O $\lambda$ máximo de suspensões de $\mathrm{Cl}$ de NS1 submetidos à pressão em pH 11,0 é de $344,5 \mathrm{~nm}$, um deslocamento de $2,3 \mathrm{~nm}$ em relação à suspensão não tratada, porém bem menor do que os $12,8 \mathrm{~nm}$ de deslocamento obtidos para $355 \mathrm{~nm}$ que foram obtidos quando os $\mathrm{Cl}$ foram completamente desnaturados pela presença de $6 \mathrm{M}$ de $\mathrm{GdnHCl}$. Esse resultado demonstra que a proteína teve um desenovelamento apenas parcial pela aplicação de alta pressão em $\mathrm{pH}$ alcalino. O pico máximo de fluorescência obtido para a suspensão de NS1 submetida à pressão em pH 8,5 e na presença de $1 \mathrm{M}$ de $\mathrm{GdnHCl}$ foi maior, de $348,0 \mathrm{~nm}$ (Figura 18A), um deslocamento de $5,8 \mathrm{~nm}$ em relação ao valor obtido em $\mathrm{pH} \mathrm{7,0} \mathrm{e} \mathrm{pressão}$ atmosférica e maior do que o obtido pelo tratamento sob pressão e em pH 11,0 o que indica que a aplicação de alta pressão na presença de $1 \mathrm{M}$ de $\mathrm{GdnHCl}$ promoveu maior grau de desenovelamento da NS1 do que a aplicação de pressão em pH 11,0. Um fato digno de nota é que aplicação de alta pressão à suspensão na presença de $2 \mathrm{M}$ de $\mathrm{GdnHCl}$ promoveu o quase completo desenovelamento da NS1, com deslocamento do $\lambda$ máximo para $353,6 \mathrm{~nm}$. O mesmo deslocamento de $5,8 \mathrm{~nm}$ (para $348 \mathrm{~nm}$ ) foi obtido para o $\lambda$ máximo do espectro de fluorescência da suspensão de CI de NS1 de ZIKV submetida à pressão em pH 10,5 e 0,4M de Arg (Figura 18C), o que demonstra que a presença de arg, também promove desenovelamento parcial da proteína. 
A

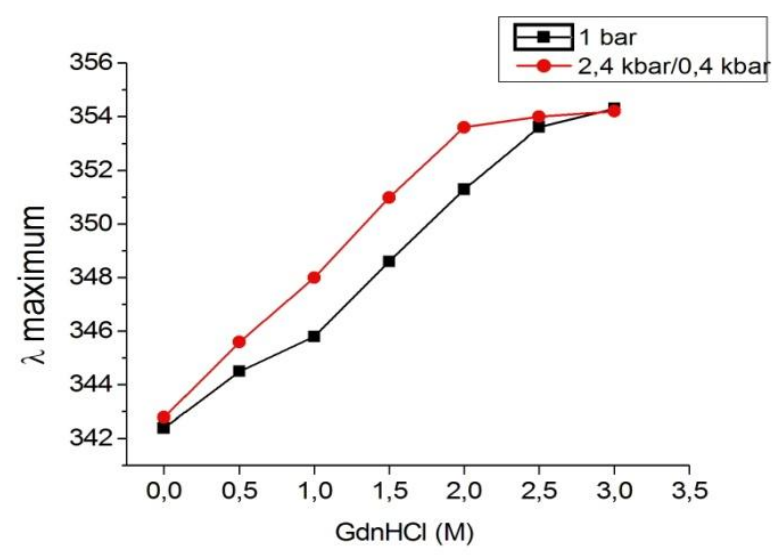

B

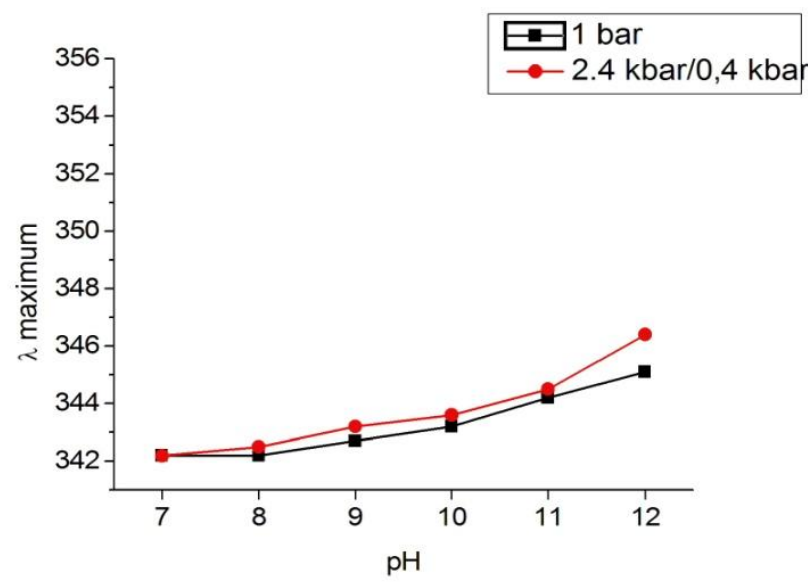

C

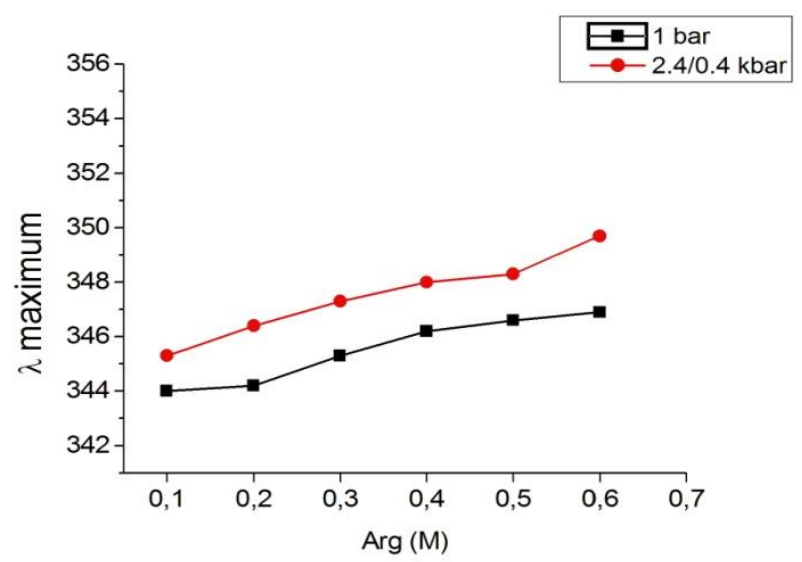

Figura 18. Efeito da alta pressão sobre o desenovelamento da proteína NS1 de ZIKV. Gráficos de fluorescência intrínseca máxima ( $\lambda$ máximo) dos $\mathrm{Cl}$ submetidos ou não à pressão $(2,4 \mathrm{kbar} / 0,4$ kbar). A: curva de $\mathrm{GdnHCl}$ em pH 8,5 ; B: Curva de pH; em pH 10,5; C: Curva de arg em pH 10,5. Os valores foram obtidos utilizando-se excitação de $290 \mathrm{~nm}$ e a emissão foi determinada entre 300 e $400 \mathrm{~nm}$. 
Na Figura 19 pode-se observar os gráficos de $A_{280 n m}$ de sobrenadantes de suspensões de $\mathrm{Cl}$ de NS1 de ZIKV que foram submetidos à pressão de 2,4 kbar por $1 \mathrm{~h} 30 \mathrm{~min}$ e de $0,4 \mathrm{kbar}$ por $14 \mathrm{~h} 30 \mathrm{~min}$ em pH 8,5 contendo diferentes concentrações de GdnHCl (Figura 19A), em diferentes pH (Figura 19B) ou em diferentes concentrações de arg em pH 10,5 (Figura 19C) e que foram em seguida dialisados contra tampão $\mathrm{TrisHCl}$ em $\mathrm{pH} 8,5$ e centrifugados para remoção de agregados insolúveis. A proteína NS1 solubilizada na presença de $\mathrm{GdnHCl}$ se mostrou altamente instável, mostrando reagregação para agregados insolúveis quando foi feita diálise para retirada deste agente desnaturante, o mesmo não ocorrendo quando a proteína foi solubilizada em $\mathrm{pH}$ mais alcalino. Valores bem maiores de absorbância em $280 \mathrm{~nm}$, que indicam maiores valores de concentração proteica, foram obtidos para a NS1 solubilizada em pH 10,0 $(0,13) \mathrm{e}$ $11,0(0,14)$ do que para as amostras solubilizadas em alta pressão na presença de $1,5 \mathrm{M}$ de $\mathrm{GdnHCl}(0,037)$. Assim, apesar de as amostras submetidas à HP em $\mathrm{GdnHCl}$ e $\mathrm{pH} 8,5$ solubilizarem eficientemente os $\mathrm{Cl}$ (Figura 17A), a NS1 solubilizada na presença de $\mathrm{GdnHCl}$ reagregou muito durante a diálise, enquanto a que foi solubilizada em pH 10,0 e 11,0 se manteve solúvel. Portanto, na busca pelas condições ótimas para a reenovelamento de NS1 de ZIKV, decidimos utilizar a condição na qual foi obtida solubilização eficiente dos agregados com menor grau de reagregação, que foi a associação de pH alcalino com a aplicação de alta pressão na presença ou na ausência de arg. 
A

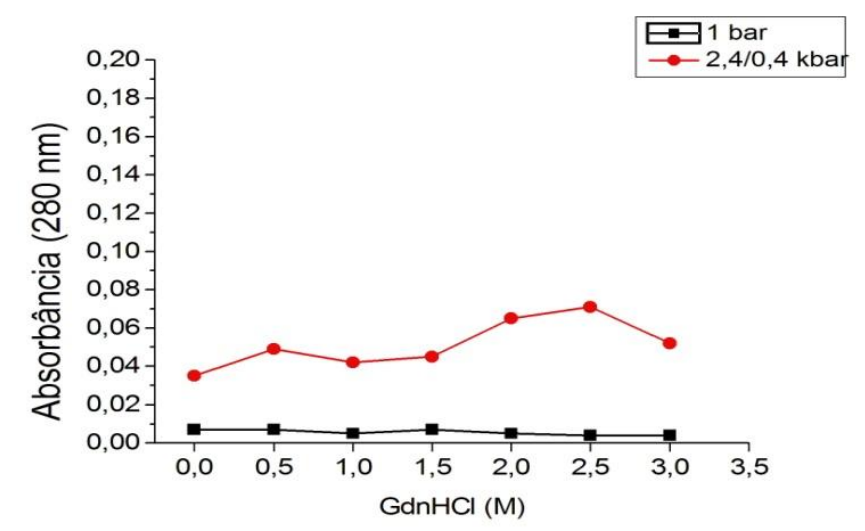

B

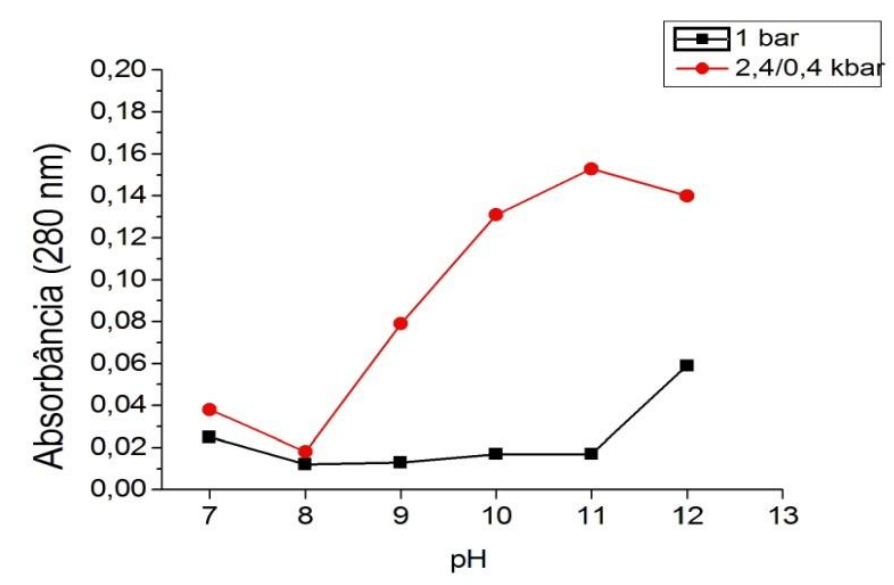

C

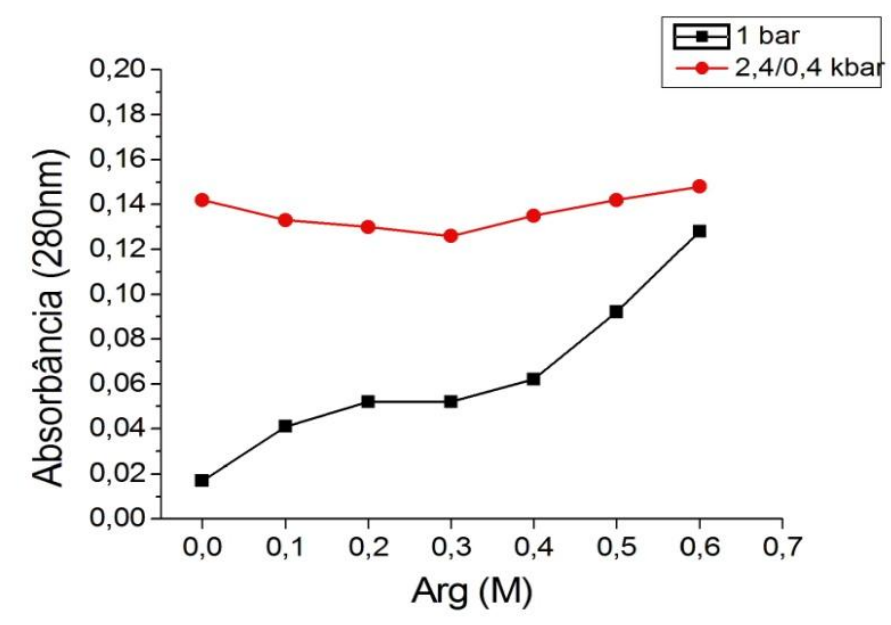

Figura 19. Efeito da GdnHCl, $\mathrm{pH}$ e arg sobre o refolding de NS1 de ZIKV. Solubilização monitorada por espectofotometria a $280 \mathrm{~nm}$ dos sobrenadantes de $\mathrm{Cl}$ submetidos e não submetidos à pressão $(2,4 \mathrm{kbar} / 0,4 \mathrm{kbar})$ e centrifugação para retirada dos agregados insolúveis e depois à diálise em tampão TrisHCl $50 \mathrm{mM}$ pH 8,5 e centrifugação. A: curva de $\mathrm{GdnHCl}$ em pH 8,5; $\mathrm{B}$ : Curva de $\mathrm{pH}$; C: Curva de arg em pH 10,5. 
A Figura 20 mostra os cromatogramas de frações solúveis de suspensões de $\mathrm{Cl}$ de NS1 de ZIKV submetidos à pressão de 2,4 kbar por 1h30min e 0,4 kbar por 14h30min em pH de 10,0 a 12,5 em coluna de exclusão molecular (Superdex 200 10/300, da GE). O tampão de eluição utilizado foi o CAPS pH 11,0. Os picos com volumes de eluição de aproximadamente $8,3 \mathrm{~mL}$ se referem a oligômeros de alto peso molecular, os picos que eluiram com volume aproximado de $11,5 \mathrm{~mL}$ provavelmente são dímeros e os picos que apresentam volume de eluição de aproximadamente $12,8 \mathrm{~mL}$ nos cromatogramas se referem a monômeros de NS1 de ZIKV. No cromatograma da NS1 solubilizada pela aplicação de pressão à suspensão de $\mathrm{Cl}$ em pH 10,0 vemos menor intensidade de absorbância do que nas outras condições, o que mostra que a concentração proteica é menor e além disso, uma porcentagem grande da proteína solubilizada nestas condições se encontra na forma de oligômeros solúveis de alto peso molecular. Entretanto, os dados mostram que houve dissociação dos oligômeros quando as suspensões de $\mathrm{Cl}$ foram submetidos à pressão em pHs mais elevados $(11,0$ a 12,5$)$ e a proteína solubilizada nessas condições se encontra majoritariamente na forma de monômeros. Os dados indicam que a presença de arg auxiliou na solubilização e dissociação de oligômeros de NS1 de ZIKV, como podemos verificar na comparação entre as amostras submetidas à compressão em $\mathrm{pH} 11,0$ e aquela que foi tratada em pH 11,0 + arg: o pico de formas oligoméricas apresenta intensidade considerável na amostra de sobrenadante de suspensão submetida à pressão em pH 11,0, mas a intensidade é menor quando a suspensão foi comprimida no mesmo pH na presença de arg. Fenômeno semelhante ocorre em $\mathrm{pH} 12,0$. Ainda na mesma figura pode-se observar que quanto mais elevado o pH, menores os volumes de retenção do monômero: para o sobrenadante da suspensão de $\mathrm{Cl}$ submetida à pressão em pH 10,0 + $\arg 0$ monômero foi eluido em 12,9 mL, baixando para 12,8 em pH 11,0 + arg, para 12,5 em pH 12,0 + arg e para 12,2 em pH 12,5 + arg. O mesmo ocorre com os volumes de eluição dos dímeros, mas não com o pico de oligômeros. A explicação para este fenômeno é a mesma já descrita para a NS1 de DENV: de que o desenovelamento da proteína NS1 é maior em pH mais alcalino, com elevação do volume da proteína. O deslocamento é mais evidente em pH de 12,0 e de 12,5. Por este motivo decidimos utilizar pH de até 11,5 e presença de arg para a solubilização/reenovelamento de NS1 de ZIKV. 

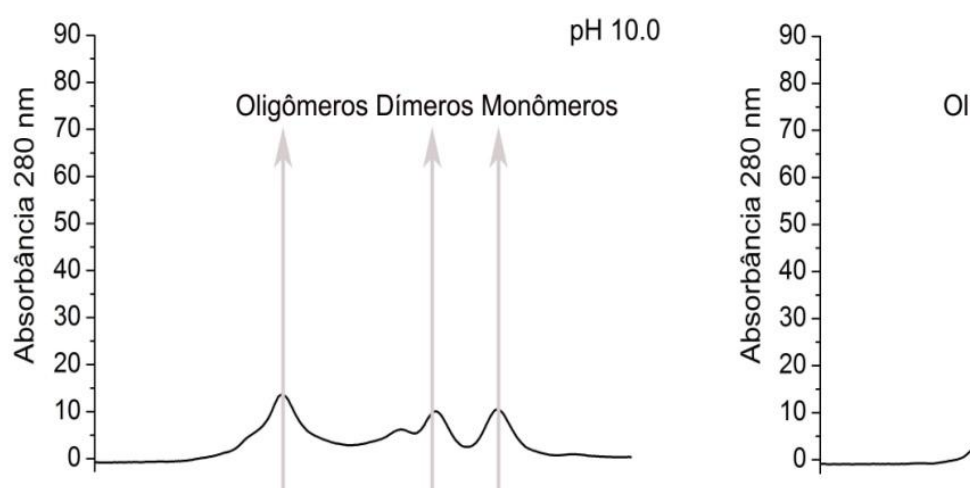

$\mathrm{pH} 10.0$ arg
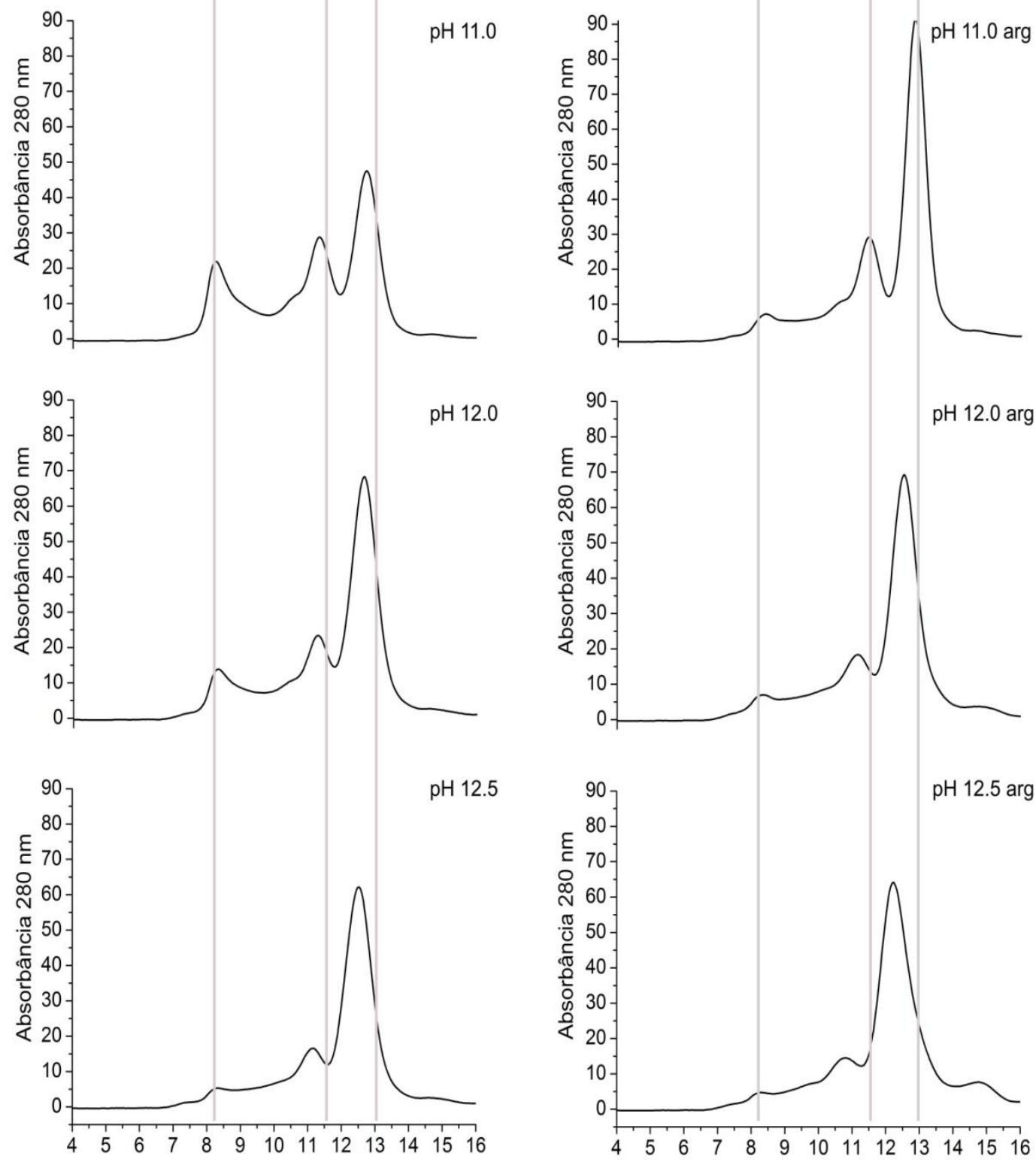

Figura 20. Cromatogramas em coluna de exclusão molecular de sobrenadantes de suspensões de $\mathrm{Cl}$ de NS1 de ZIKV submetidas à pressão de 2,4 kbar por $1 \mathrm{~h} 30$ min e 0,4 kbar por 14h30min eluidas em tampão CAPS pH 11,0. As suspensões foram submetidas à pressão em pH de $10,0 \mathrm{a}$ 12,5 na presença de $0,4 \mathrm{M}$ de arginina ou na sua ausência. Foram aplicados $500 \mu \mathrm{l}$ em coluna Superdex 200 10/300 (GE Biosciences). 
Na Figura 21 vemos a análise por do SDS-PAGE das frações solúveis de suspensões de $\mathrm{Cl}$ de NS1 de ZIKV em pH 11,0 e 11,5 submetidos à pressão de 2,4 kbar por 1h30min kbar e a 0,4 kbar por 14h30min na ausência e na presença de arg e dialisadas contra tampão TrisHCl em pH 8,5 em comparação com o mesmo volume da suspensão de $\mathrm{Cl}$ original (coluna $\mathrm{Cl}$ ). $\mathrm{O}$ rendimento de reenovelamento de NS1 de ZIKV em relação à quantidade de proteína nos $\mathrm{Cl}$ também foi elevado para a proteína deste vírus. As porcentagens determinadas pela análise utilizando o programa Image $\mathrm{J}$ da fotografia mostrada na Figura 21 foram de aproximadamente $77,5 \%$ para a proteína reenovelada sem arginina e maiores: de aproximadamente 95,0 \% para as amostras submetidas à pressão na presença de arg. A presença de arg auxiliou na dissociação das formas de alto peso molecular, como se pode observar na comparação entre as amostras não reduzidas que foram submetidas à compressão na ausência e na presença deste aminoácido. Enquanto a proteína das amostras comprimidas na presença de arg se encontra majoritariamente na posição de monômeros, a NS1 das amostras comprimidas na ausência de arg se encontra majoritariamente no topo do gel. Esses resultados corroboram os dados obtidos pela análise por cromatografia de exclusão molecular (Figura 20).

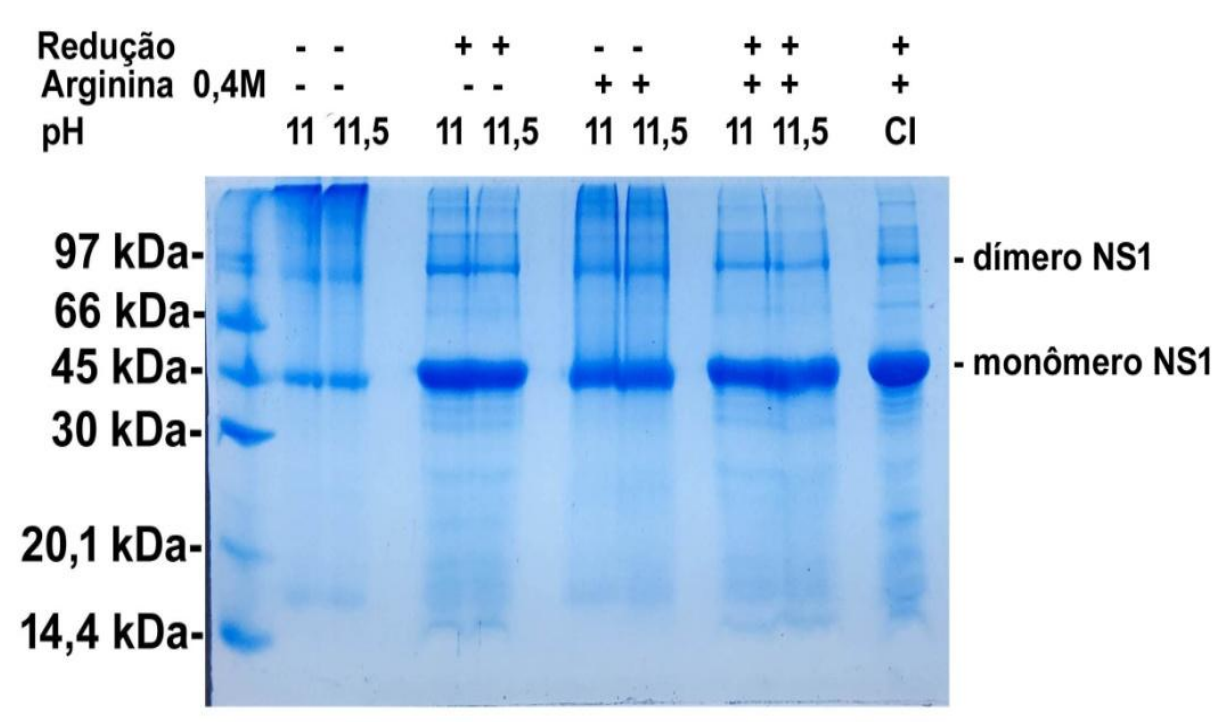

Figura 21. Amostras de NS1 ZIKV reenoveladas pela aplicação de alta pressão (2,4 kbar/0,4 kbar) em $\mathrm{pH} 11,0$ e 11,5 na ausência e presença de 0,4M de arg, analisadas por SDS-PAGE. Os sobrenadantes de amostras submetidas à pressão e dialisados foram aplicados no gel de eletroforese. As amostras não foram fervidas, com exceção da amostra de suspensão de $\mathrm{Cl}$ que foi fervida e reduzida. A redução foi obtida pela adição de DTT 100 mM as amostras. 
A fim de verificarmos se a proteína NS1 de ZIKV solubilizada dos $\mathrm{Cl}$ em alta pressão (2,4 kbar) e em pH alcalino é capaz de ser reenovelar eficientemente em pressão atmosférica, ou se a incubação em diferentes tempos de pressão intermediária $(0,4 \mathrm{kbar})$ pode ser útil para elevar o rendimento do redolding da NS1, foram testadas diferentes condições de descompressão. A compressão foi realizada em 2,4 kbar por $1 \mathrm{~h} 30$ minutos, e a descompressão foi feita diretamente para pressão atmosférica (condição 1) ou foram feitas incubações em 0,4 kbar por $6 \mathrm{~h} 30$ min (condição 2) ou por 14h30min (condição 3) antes da descompressão completa. Pela análise dos SDS-PAGE da Figura 22, podemos verificar que não houve grandes diferenças no nível de solubilização da proteína (Figura 22B). Mas, de modo geral as bandas de $45 \mathrm{kDa}$ e de $90 \mathrm{kDa}$ mais intensas podem ser observadas nas amostras que foram incubadas na condição 2 (Figura 22A) $(2,4$ kbar por 90 minutos e 0,4 kbar por 6h30min) do que nas condições 1 ou 3 .

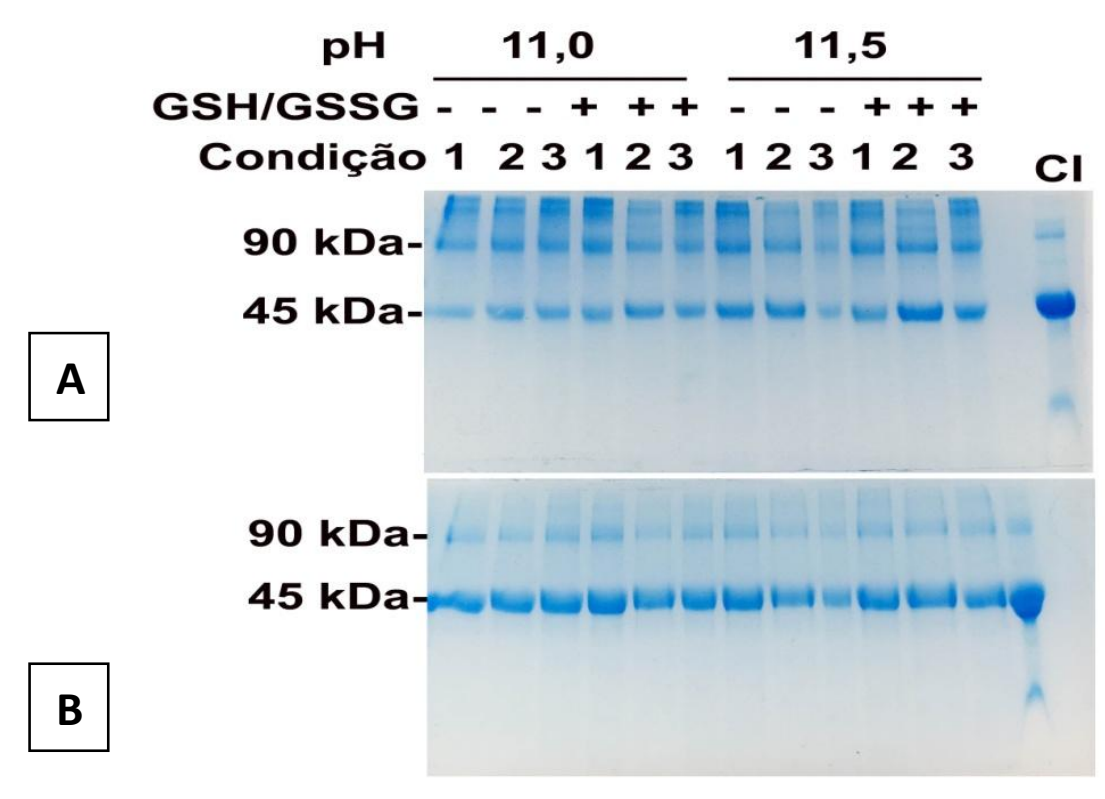

Figura 22. SDS-PAGE para analise de sobrenadantes de $\mathrm{CI}$ de NS1 ZIKV submetidos à pressão em $\mathrm{pH} 11,0$ e 11,5 na presença de $0,4 \mathrm{M}$ de arg e na presença ou ausência de $1 \mathrm{~mm}$ GSH e $0,1 \mathrm{~mm}$ de GSSG, conforme indicado na figura, e dialisadas. Condições: tempos de pressão/descompressão: 1: 1h30min. em 2,4 Kbar; 2: 1h30min. em 2,4 kbar e 6h30min. em 0,4 kbar; 3: 1h30min. em 2,4 kbar e $14 \mathrm{~h} 30 \mathrm{~min}$. em 0,4 kbar. Na imagem A as amostras não foram reduzidas e na imagem $B$ foram reduzidas pela adição de DTT $100 \mathrm{mM}$ às amostras. As amostras não foram fervidas, com exceção dos $\mathrm{Cl}$, que foram fervidos e reduzidos nos dois géis. 
Foram realizados testes de imunoabsorção de ELISA a fim de avaliarmos a reatividade de NS1 de ZIKV reenoveladas em diferentes pHs e presença ou ausência de GSH e GSSH durante o processo de compressão. Todas as amostras analisadas apresentaram alto reatividade quando os soros positivos para ZIKV foram utilizados e muito baixa reatividade quando soros de indivíduos que não haviam sido infectados por este vírus foram utilizados (Figura 23). Os sobrenadantes dialisados das amostras que foram submetidas à compressão em pH 11,0 com arg, pH 11,0 com arg e GSH/GSSG e pH 11,5 com arg e o par de glutationas apresentaram reatividade semelhante a da proteína NS1 de ZIKV produzida no Laboratório de Desenvolvimento de Vacinas (LDV). Além disso, em indivíduo não infectado por ZIKV a reatividadeos foi e semelhante entre as proteínas reenoveladas utilizando alta pressão e a NS1 do LDV.

Também para o caso da NS1 de ZIKV os anticorpos do soro de paciente previamente infectado com o ZIKV reconhecem epítopos conformacionais da proteína NS1 (linhas pretas), como comprovado pela queda dos valores de absorbância quando os soros foram incubados com a NS1 desnaturada por aquecimento (linhas vermelhas) (Figura 24). 


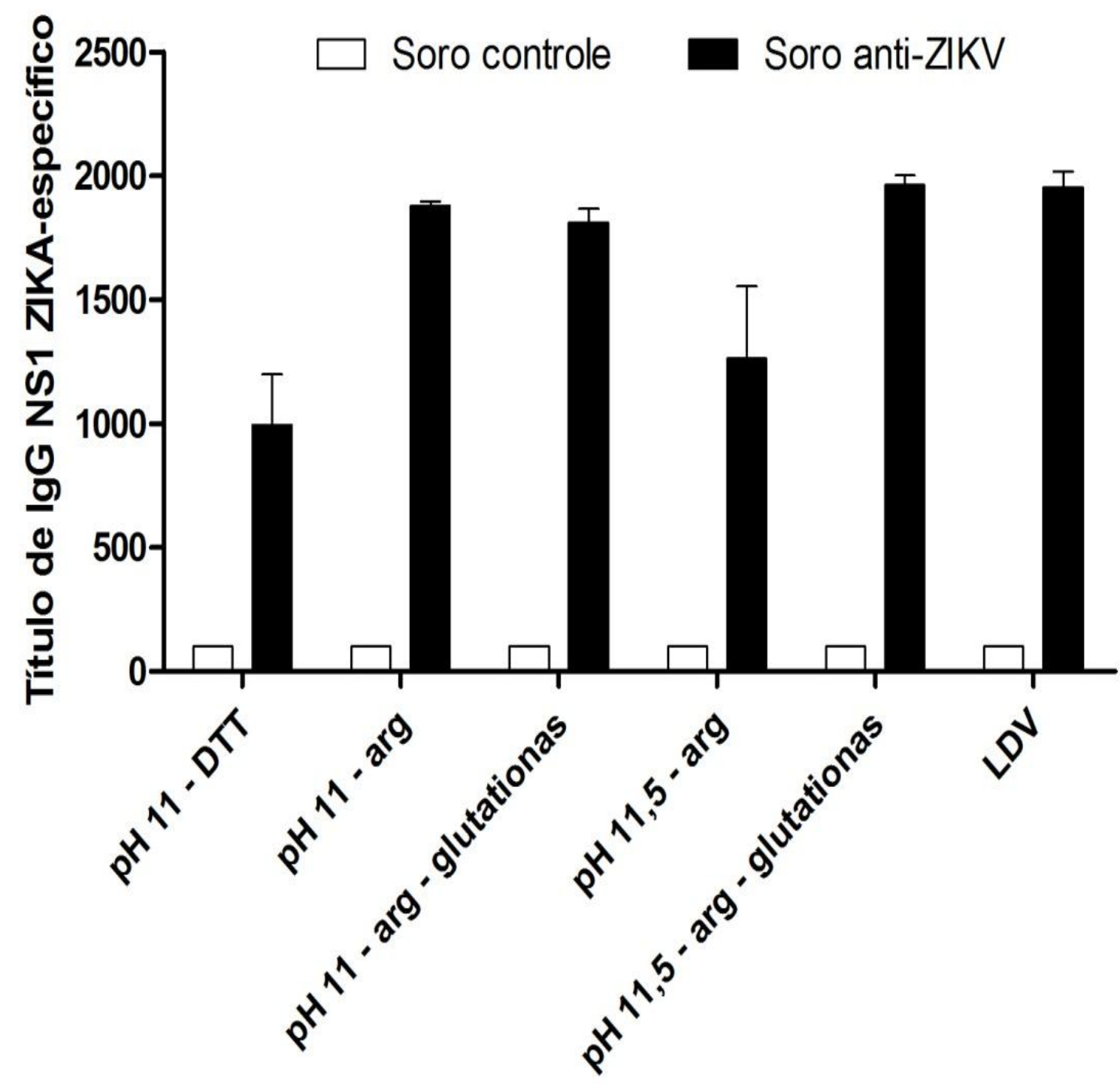

Figura 23. Avaliação da reatividade da proteína NS1 de ZIKV obtida em diferentes condições de refolding. Alíquotas da proteína NS1 (2ng/ $\mu \mathrm{l})$ obtidas em diferentes condições de reenovelamento foram utilizadas como antígeno de fase sólida em ensaios de ELISA empregando soros controles obtidos de pacientes previamente infectados (barras pretas) ou não (barras brancas) com o vírus da zika. Os valores são expressos em média \pm erro dos títulos de anticorpos lgG antígeno específicos. A compressão dos $\mathrm{Cl}$ foi realizada em 2,4 kbar por 1h30min e em 0,4 kbar por 6h30min. LDV: NS1 obtida do mesmo clone utilizado no nosso trabalho e reenovelada no Laboratório de Desenvolvimento Vacinal. 
A)

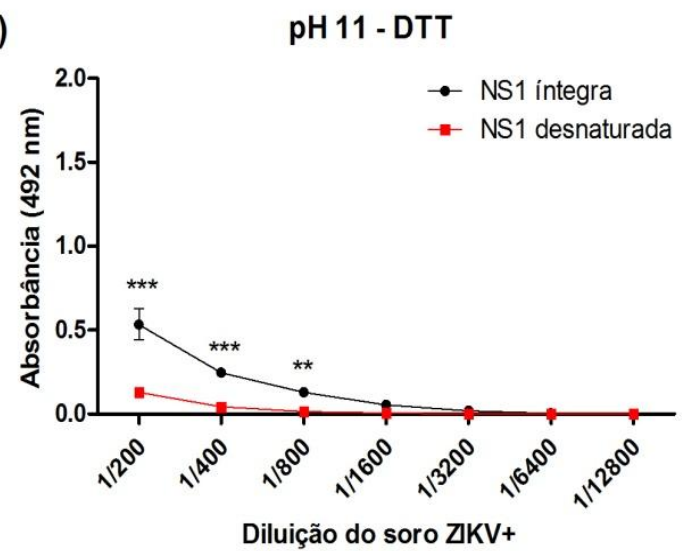

B)

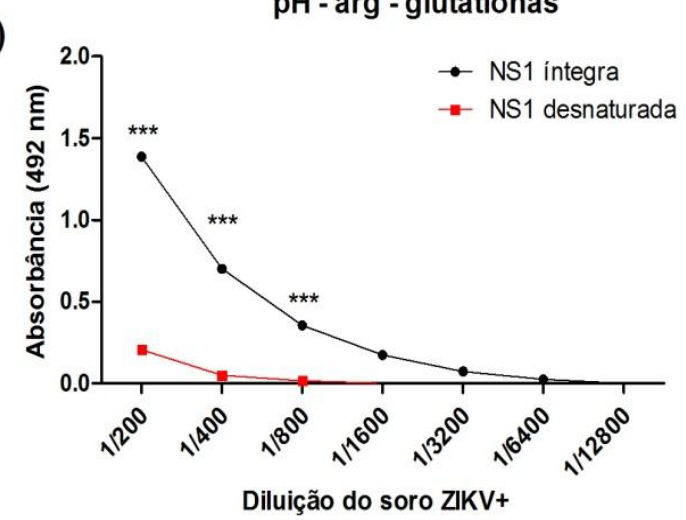

C)

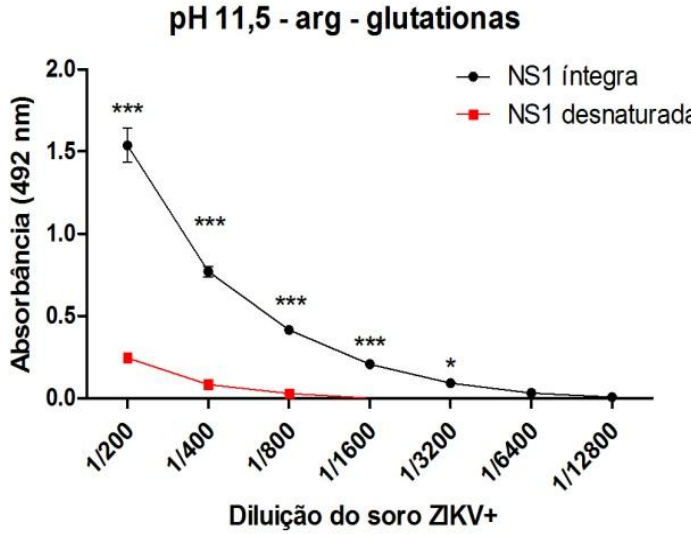

D)

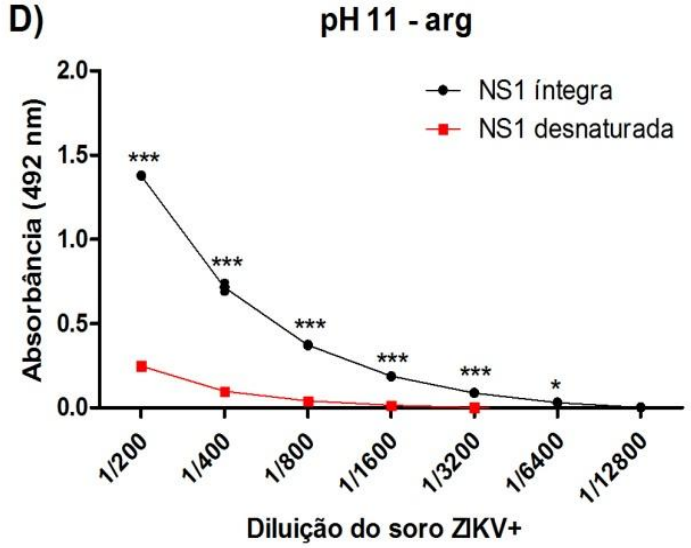

pH 11,5 - arg

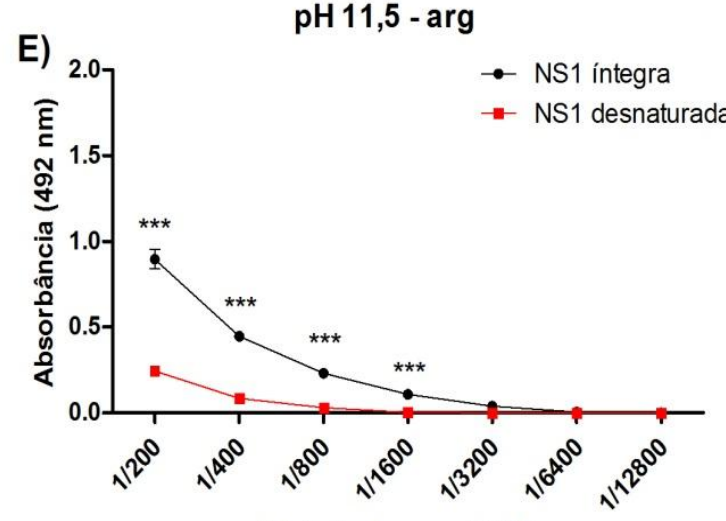

Diluição do soro ZIKV+

F)

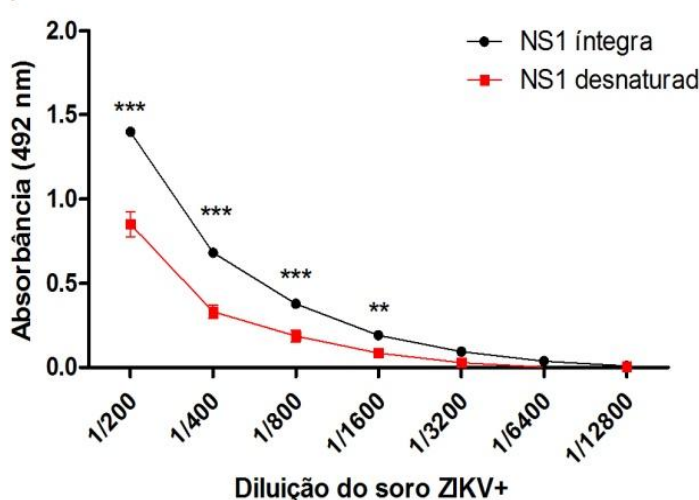

Figura 24. Avaliação da preservação de epítopos conformacionais da proteína NS1 de ZIKV obtida

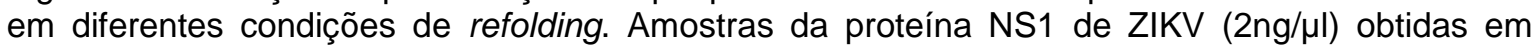
diferentes condições de reenovelamento submetidas ou não previamente à desnaturação (aquecimento a $100{ }^{\circ} \mathrm{C}$ por $10 \mathrm{~min}$. seguido de choque térmico à $0{ }^{\circ} \mathrm{C}$ ) foram analisadas por ELISA quanto a sua reatividade com soro de paciente previamente infectado com o ZIKV. Os valores obtidos são expressos em média \pm erro da absorbância obtida no ensaio. ${ }^{*} p<0,05$; ${ }^{* *} p<0,01 ;{ }^{* *} p<0,001$. (Two-way ANOVA com teste de Bonferroni). A compressão dos $\mathrm{Cl}$ foi realizada em 2,4 kbar por 1h30min e em 0,4 kbar 6h30min. LDV: NS1 obtida do mesmo clone utilizado no nosso trabalho e reenovelada no Laboratório de Desenvolvimento Vacinal. 
Os rendimentos de obtenção de NS1 solúvel e reenovelada em comparação com a proteína nos $\mathrm{Cl}$ foram calculados pela análise da imagem mostrada na Figura 25. Foram obtidos entre 79\% e 89\%, de proteína solúvel a partir da suspensão de $\mathrm{Cl}$ de NS1. A presença de DTT (2mM) aumentou o rendimento do refolding para $96 \%$, mas como a sua presença durante a compressão provocou uma perda de reatividade da NS1 produzida (Figura 23), a utilização deste reagente no processo de refolding foi desconsiderada. Pela analise em SDS-PAGE (Figura 25) podemos também observar que a proteína NS1 se encontra praticamente pura.

\section{Amostras}

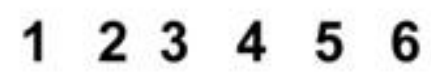

\section{BSA 1223456}

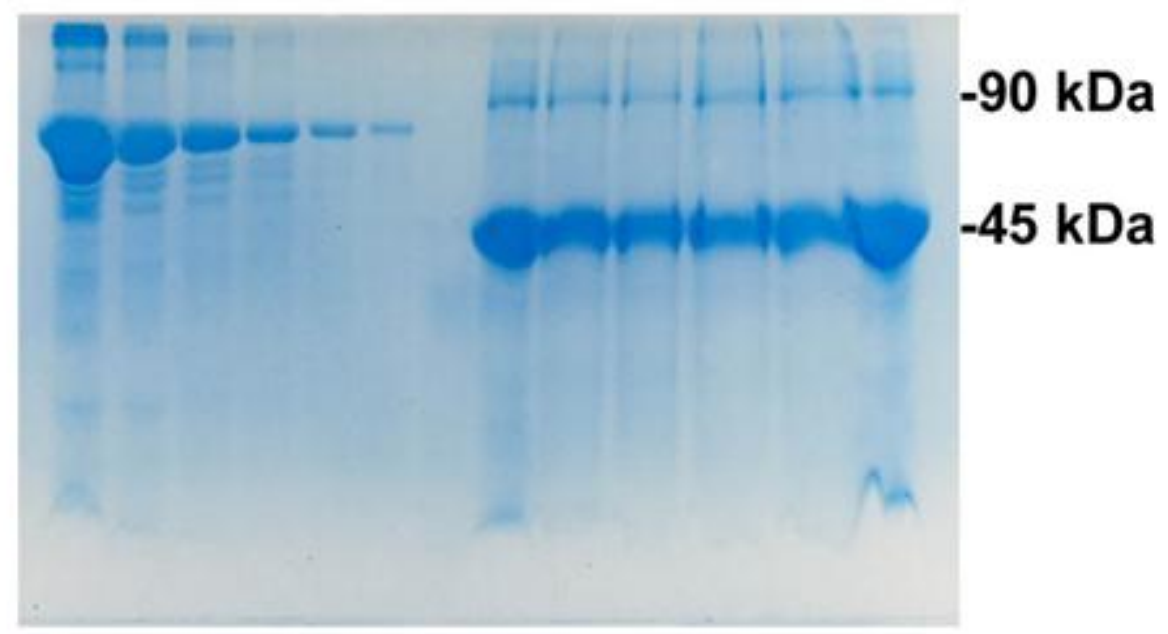

Figura 25. Curva de BSA e amostras de NS1 de ZIKV reenovelada em pH 11,0 e 11,5 analisadas por SDS-PAGE. Colunas 1 a 6 da linha "BSA": BSA nas concentrações de $1 \mathrm{mg} / \mathrm{mL}, 0,5 \mathrm{mg} / \mathrm{mL}$, $0,25 \mathrm{mg} / \mathrm{mL}, 0,125 \mathrm{mg} / \mathrm{mL}, 0,062 \mathrm{mg} / \mathrm{mL}$ e $0,031 \mathrm{mg} / \mathrm{mL}$. Linha "amostras": coluna 1: NS1 reenovelada em $\mathrm{pH} 11,0 \mathrm{com} 2 \mathrm{mM}$ DTT, coluna 2: NS1 reenovelada em $\mathrm{pH} 11,0 \mathrm{com} 0,4 \mathrm{M}$ de arg, coluna 3: NS1 reenovelada em pH 11,0 com 0,4M de arg e $1 \mathrm{mM}$ de GSH e 0,1mM de GSSG, coluna 4: NS1 reenovelada em pH 11,5 com 0,4M de arg; coluna 5: NS1 reenovelada em pH 11,5 com $0,4 \mathrm{M}$ de arg, $1 \mathrm{mM}$ de GSH e 0,1mM de GSSG; coluna 6: suspensão de Cl. Todas as amostras foram reenoveladas na condição 2 de compressão/descompressão. Todas as amostras foram reduzidas com $100 \mathrm{mM}$ de DTT e fervidas.

Considerando que também neste caso o nível de contaminação dos $\mathrm{Cl}$ de NS1 por proteínas de E. coli é baixo (Figura 25), utilizamos a determinação de absorbância a $280 \mathrm{~nm}$, utilizando $\circ$ valor de Abs $0,1 \%=2,111$ para a 
quantificação da proteína. Os valores da quantificação por $\mathrm{A}_{280 \mathrm{~nm}}$ da NS1 de ZIKV, assim como foi obtido para a NS1 de DENV, foram aproximadamente $40 \%$ menores do que quando a dosagem foi realizada por comparação com uma curva de BSA em gel de SDS-PAGE. A Tabela 3 mostra os rendimentos de proteína por $\mathrm{mg} / \mathrm{mL}$ e também a quantidade de proteína obtida a partir de 1 litro de cultura bacteriana. O valor de $68,1 \mathrm{mg} / \mathrm{L}$ de cultura foi obtido para a condição de reenovelamento em pH 11,5 contendo arg e GSH/GSSG, uma condição que se apresentou bem no ensaio de reatividade (imunoabsorção) (Figuras 23 e 24). $O$ rendimento de reenovelamento de NS1 de ZIKV descrito no presente trabalho é mais de 27,5 vezes superior ao rendimento obtido pelo reenovelamento desta proteína em pressão atmosférica (Tabela 3) utilizando o método descrito pelo grupo do LDV (AMORIM et al., 2010), sendo que os $\mathrm{Cl}$ foram produzidos nas mesmas condições, e ambas apresentam reatividade similar (Figuras 23 e 24). 
Tabela 3. Quantificação por $A_{280 n m}$ de NS1 de ZIKV de amostras reenoveladas pela aplicação de pressão (2,4 kbar por 90 min e 0,4 kbar por 6h30min).

\begin{tabular}{|c|c|c|}
\hline Condições de Refolding & $\begin{array}{l}\text { Quantificação } \\
\text { por } \mathrm{A}_{280 \mathrm{~nm}}\end{array}$ & $\begin{array}{l}\text { Quantidade de NS1 } \\
\text { reenovelada/litro de } \\
\text { cultura bacteriana }\end{array}$ \\
\hline pH 11,0 - DTT 2mM & $0,618 \mathrm{mg} / \mathrm{ml}$ & $102,6 \mathrm{mg} / \mathrm{L}$ \\
\hline $\mathrm{pH} 11,0-\arg 0,4 \mathrm{M}$ & $0,336 \mathrm{mg} / \mathrm{ml}$ & $42,8 \mathrm{mg} / \mathrm{L}$ \\
\hline $\begin{array}{c}\mathrm{pH} 11,0-\arg 0,4 \mathrm{M}-\mathrm{GSH} 1 \mathrm{mM}- \\
\text { GSSG } 0,1 \mathrm{mM}\end{array}$ & $0,349 \mathrm{mg} / \mathrm{ml}$ & $44,5 \mathrm{mg} / \mathrm{L}$ \\
\hline $\mathrm{pH} 11,5-\arg 0,4 \mathrm{M}$ & $0,344 \mathrm{mg} / \mathrm{ml}$ & $43,8 \mathrm{mg} / \mathrm{L}$ \\
\hline $\begin{array}{c}\mathrm{pH} 11,5-\arg 0,4 \mathrm{M}-\mathrm{GSH} 1 \mathrm{mM}- \\
\text { GSSG } 0,1 \mathrm{mM}\end{array}$ & $0,534 \mathrm{mg} / \mathrm{ml}$ & $68,1 \mathrm{mg} / \mathrm{L}$ \\
\hline $\begin{array}{l}\text { LDV: NS1 renaturada no Laboratório } \\
\text { de Desenvolvimento Vacinal }\end{array}$ & & $2.0-3,0 \mathrm{mg} / \mathrm{L}^{*}$ \\
\hline
\end{tabular}




\section{CONCLUSÕES}

Os resultados que obtivemos com os nossos experimentos nos levaram às seguintes conclusões:

- A associação de alta pressão em pH alcalino é capaz de solubilizar a proteína NS1 agregada como $\mathrm{Cl}$ de dengue para trímeros, dímeros e monômeros e a NS1 de zika para dímeros e monômeros;

- A presença de arg 0,4M auxilia na dissociação dos oligômeros solúveis;

- A proteína NS1 de DENV e de ZIKV obtidas por tratamento dos Cl em 2,4 kbar na presença de 0,4M de arg seguida de diálise em Tris HCl pH 8,5 apresenta reatividade por imunoabsorção comparável à mesma proteína reenovelada utilizando protocolos estabelecidos.

Foram obtidos altos níveis de NS1 de DENV (104 mg/litro de cultura) e de ZIKV (68 mg/litro de cultura) solúveis e reativas a partir de $\mathrm{Cl}$ dessas proteínas. Os rendimentos de proteína solúvel em comparação com a NS1 nos Cl extraídos de bactérias $E$. coli e lavados foram de aproximadamente $90 \%$ para a NS1 de DENV e de 79\% para a NS1 de ZIKV.

As condição escolhida para o refolding de NS1 de DENV foi a aplicação de pressão (2,4 kbar por 1 h30 min e 0,4 kbar por 6h30min) a uma suspensão de $\mathrm{Cl}$ em $\mathrm{pH} 10,5$ na presença de $1 \mathrm{mM}$ de EDTA, arg $(0,4 \mathrm{M})$, GSH (1mM) e GSSG (0,1mM) seguida de diálise em TrisHCI pH 8,5.

As condição escolhida para o refolding de NS1 de ZIKV foi a aplicação de pressão (2,4 kbar por 1 h30 min e 0,4 kbar por 6h30min) a uma suspensão de Cl em $\mathrm{pH} 11,5$ na presença de $1 \mathrm{mM}$ de EDTA, arg $(0,4 \mathrm{M})$, GSH $(1 \mathrm{mM})$ e GSSG $(0,1 \mathrm{mM})$ seguida de diálise em TrisHCl $\mathrm{pH} 8,5$.

\subsection{Considerações finais}

No presente estudo foi feita uma análise minuciosa das condições mínimas de $\mathrm{pH}$ e presença de arginina necessárias para a solubilização dos agregados de NS1 de ZIKV e de DENV em alta pressão. Não temos conhecimento de artigos da literatura que tenham relatado este tipo de análise para a otimização de processos de refolding de proteínas. 
Alguns artigos da literatura descrevem a utilização de altas pressões para a dissociação de agregados insolúveis em condições que são relativamente pouco desnaturantes e que possibilitam o reenovelamento destas proteínas. Entretanto, de modo geral, a aplicação de altas pressões não é suficiente para a dissociação eficiente dos agregados proteicos. Por este motivo, em muitos dos casos é descrita a utilização concomitante de concentrações baixas de agentes caotrópicos e a aplicação de alta pressão para solubilização eficiente dos agregados e posterior reenovelamento (CHURA-CHAMBI et al., 2008; 2013; ST JOHN et al., 2001; 2002).

Também foi descrita a utilização de $\mathrm{pH}$ alcalino para a solubilização de corpúsculos de inclusão, com o objetivo de obtenção de refolding de proteínas com a conformação próxima a nativa. Também neste caso, a solubilização eficiente somente é obtida pela adição de agentes caotrópicos (2M de ureia) (PATRA et al., 2000). SINGH e colaboradores (2008) descrevem o refolding de 7 proteínas que foram solubilizadas em pH 12 e na presença de $2 \mathrm{M}$ de uréia e em seguida diluídas por diluição pulsada em tampão em pH 8,5. Os rendimentos variam entre $30 \%$ a $40 \%$. Entretanto, pelo que é de nosso conhecimento, não foi descrito na literatura processo que utilize a aplicação de alta pressão hidrostática à suspensão de agregados insolúveis em $\mathrm{pH}$ alcalino com a finalidade de solubilização de agregados proteicos visando o refolding de proteínas. A combinação dos dois fatores - alta pressão hidrostática e pH alcalino - se provou extremamente eficiente, promovendo a solubilização dos agregados insolúveis, com baixo grau de desnaturação da proteína solubilizada, obtenção de alto rendimento de proteínas solúveis e biologicamente ativas, por meio de um processo rápido e com rendimentos de produção de proteína mais elevados do que a associação de alta pressão e presença de $\mathrm{GdnHCl}$, como demonstrado nas Figuras 6 e 19. O rendimento de NS1 de DENV foi de 29,7 e o de ZIKV foi de 27,5 vezes mais elevado do que o processo de refolding por diluição pulsada da proteína solubilizada em $8 \mathrm{M}$ de uréia em pressão atmosférica descrito por nossos colaboradores (AMORIM et al., 2010), sendo que as proteínas apresentam reatividade similar.

Os processos de refolding da NS1 de DENV e de ZIKV utilizando alta pressão, $\mathrm{pH}$ alcalino e presença de arg são extremamente simples, envolvendo somente duas etapas: a incubação em alta pressão (2,4 kbar e 0,4 kbar) por 8 
horas, seguido de diálise para abaixar o $\mathrm{pH}$. Além disso, o processo de refolding é feito com as proteínas em alta concentração (acima $0,4 \mathrm{mg} / \mathrm{mL}$ ). Não há a necessidade de diluição da proteína para evitar reagregação e depois etapas para concentração, o que é usual nos processos de refolding em pressão atmosférica.

Devido ao fato de termos obtido tão bons resultados com um processo inovador, foi feito o depósito de pedido de patente no INPI sobre este processo de renaturação (Processo BR 102017009328 0): "Processo de Renaturação de Proteínas Recombinantes a Partir de Agregados Proteicos Insolúveis".

Ensaios de ELISA foram utilizados para analisar a reatividade das proteínas NS1 de DENV e de ZIKV em comparação com as proteínas que foram solubilizadas em solução contendo $8 \mathrm{M}$ de uréia, purificadas em resina de afinidade a metais imobilizadas e reenoveladas utilizando o método tradicional em pressão atmosférica (AMORIM et al., 2010). Apesar de as NS1 reenoveladas no presente estudo não terem sido submetidas à processos de purificação, observamos que os soros de indivíduos negativos para DENV/ZIKV apresentaram ligação semelhante ou menor a esses antígenos reenovelados utilizando alta pressão do que os preparados utilizando o método convencional de refolding, conforme se pode observar nas Figuras 12 e 23. Por este motivo acreditamos que caso os $\mathrm{Cl}$ sejam lavados para eliminar contaminantes bacterianos, as proteínas reenoveladas utilizando o processo de alta pressão em associação com $\mathrm{pH}$ alcalino poderiam ser utilizadas para a preparação de ensaios imunodiagnósticos sem a necessidade de purificação. Entretanto, estudos posteriores necessitariam ser realizados sobre a utilização destas proteínas como antígenos vacinais.

Não constam na literatura processos de refolding de NS1 de ZIKV. Alguns processos de refolding de NS1 de dengue foram descritos na literatura utilizando $8 \mathrm{M}$ de uréia para a solubilização dos $\mathrm{Cl}$. Entretanto, os rendimentos foram baixos se compararmos com os rendimentos por nós obtidos no presente estudo. No artigo de ATHMARAN e colaboradores (2013), foram obtidos 4,2 mg de NS1 de dengue reenovelada e purificada/litro de cultura. No estudo relatado por AMORIM e colaboradores (2010), foram obtidos 3,5 mg desta proteína/litro de cultura. O estudo de ALLONSO e colaboradores (2011), relata um rendimento de 66\% de NS1 imunológicamente ativa a partir de CI de NS1 de DENV, mas não informam o rendimento por litro de cultura de bactérias. $O$ único artigo que relata um rendimento maior do que o obtido no presente estudo ( $139 \mathrm{mg} / \mathrm{L}$ de cultura) foi 
o de DAS e colaboradores (2009). Entretanto, a qualidade desta proteína não foi testada pelos autores, em ensaios de ELISA. Além disso, a quantidade de proteína obtida por litro de cultura é bastante alta ( $232 \mathrm{mg} / \mathrm{L}$ de cultura) e os altos níveis de NS1 obtidos podem ser um reflexo desta ótima expressão. Todos estes processos são mais demorados e trabalhosos do que o processo descrito neste estudo. 


\section{REFERÊNCIAS BIBLIOGRÁFICAS}

AKEY, D.L.; BROWN, W.C.; DITTA, S.; KONWERSKI, J.; JOSE, J.; JURKIW, T.J.; DELPROPOSTO, J.; OGATA, C.M.; SKINIOTIS, G.; KUHN, R.J.; SMITH, J.L.: Flavivirus NS1 structures reveal surfaces for associations with membranes and the immune system. Science 343:881-885, 2014.

AKEY, D.L.; BROWN, W.C.; KONWERSKI, J.; OGATA, C.M.; SMITH, J.L.: Use of massively multiple merged data for low-resolution S-SAD phasing and refinement of flavivirus NS1. Acta Crystallogr D Biol Crystallogr 70:2719-2729, 2014.

ALLONSO D.; da SILVA R.M.; COELHO D.R.; da COSTA, S.M.; NOGUEIRA, R.M.; BOZZA, F.A.; SANTOS, F.B.; BARCELOS ALVES, A.M.; MOHANABORGES,R.: Polyclonal antibodies against properly folded Dengue virus NS1 protein expressed in E. coli enable sensitive and early dengue diagnosis. J Virol Methods, v. 175, n. 1, p. 109-116, 2011.

AMI, B.; NATALELLO, A.; TAYLOR, G.; GIANCARLO, T.; DOGLIA, S.M.: Structural analysis of protein inclusion bodies by Fourier transform infrared microspectroscopy. Biochimica et Biophysica acta - Proteins and Proteomics, v. 1764, n. 4, p. 793-799, 2006.

AMORIM J.H.; PORCHIA, B.F.M.M.; BALAN A.; CAVALCANTE, R.C.; Da COSTA, S.M.; de BARCELOS ALVES, A.M.; de SOUZA FERREIRA, L.C.:

Refolded dengue virus type 2 NS1 protein expressed in Escherichia coli preserves structural and immunological properties of the native protein. Journal of Virological Methods, v.167, n. 2, p. 186-192, 2010.

AMORIM J.H.; ALVES R.P.; BOSCARDIN S.B.; de SOUZA FERREIRA, L.C.: The dengue virus non-structural 1 protein: risks and benefits. Virus Res, v. 181, p. 5360, 2014.

ATHMARAM T.N.; SARASWAT S.; MISRA P.; SHRIVASTANA, S.; SINGT, A.K.; VERMA, S.K.; RAO, P.V.L.: Optimization of Dengue-3 recombinant NS1 protein expression in E. coli and in vitro refolding for diagnostic applications. Virus Genes, v. 46, n. 2, p. 219-230, 2013.

AVIRUTNAN P.; FUCHS, A,; HAUHART, R.E.; SOMNUKE, P.; BLOM, A.M.; DIAMOND, M.S.; ATKINSON, J.P.: Antagonism of the complement component C4 by flavivirus nonstructural protein NS1. J Exp Med, v. 207, n. 4 , p. 793-806, 2010.

AVIRUTNAN, P.; HAUHART, R.E.; SOMNUKE, P.; BLOM, A.M.; DIAMOND, M.S.; ATKINSON, J.P : Binding of flavivirus nonstructural protein NS1 to C4b binding protein modulates complement activation. J Immunol, v. 187, n. 1, p. 424433, 2011. 
BALM, M.N.; LEE C.K.; LEE H.K.; CHIU, S.; KOAY, E.L.; TANG, J.W.: A diagnostic polymerase chain reaction assay for Zika virus. J Med Virol, v. 84, n. 9, p. 1501-1505, 2012.

BURGESS, R.R.: Refolding Solubilized Inclusion Body Proteins. Guide to Protein Purification, Second Edition 463:259-282, 2009.

BURSTEIN, E.A.; VEDENKINA, N.S.; IVKOVA, M.N.: Fluorescence and the location of tryptophan residues in protein molecules. Photochem Photobiol, v. 18, n. 4, p. 263-279, 1973.

CALVET, G.A.; SANTOS, F.B.; SEQUEIRA, P.C.: Zika virus infection: epidemiology, clinical manifestations and diagnosis. Curr Opin Infect Dis, v. 29, n. 5 , p. 459-466, 2016.

CARRIO, M.; GONZALEZ-MONTALBAN, N.; VERA, A.; VILLAVERDE, A.; VENTURA, S.: Amyloid-like properties of bacterial inclusion bodies. Journal of Molecular Biology, v.347, n. 5, p. 1025-1037, 2005.

CHUNG, K.M.; LISZEWSKI, M.K.; NYBAKKEN, G.; DAVIS, A.E.; TOWNSEND, R.R.; FREMONT, D.H.; ATKINSON, J.P.; DIAMOND, M.S.: West Nile virus nonstructural protein NS1 inhibits complement activation by binding the regulatory protein factor H. Proc Natl Acad Sci U S A, v. 103, n. 50, p. 19111-19116, 2006.

CHURA-CHAMBI, R.M.; GENOVA, L.A.; AFFONSO, R.; MORGANTI, L.: Refolding of endostatin from inclusion bodies using high hydrostatic pressure. Anal Biochem, v. 379, n. 1, p. 32-39, 2008.

CHURA-CHAMBI, R.M.; CORDEIRO, Y.; MALAVASI, N.V.; LEMKE, L.S.; RODRIGUES, D.; MORGANTI, L.: An analysis of the factors that affect the dissociation of inclusion bodies and the refolding of endostatin under high pressure. Process Biochemistry, v. 48, n. 2, p. 250-259, 2013.

CLARK, E.D.B.: Refolding of recombinant proteins. Curr Opin Biotechnol, v. 9, p. 157-163, 1998.

CRISMAN, R.L.; RANDOLPH, T.W.: Refolding of proteins from inclusion bodies is favored by a diminished hydrophobic effect at elevated pressures. Biotechnol Bioeng 102:483-492, 2009.

DAS, D.; MONGKOLAUNGKOON, S.; SURESH, M.R.: Super induction of dengue virus NS1 protein in E. coli. Protein Expr Purif, v. 66, n. 1, p. 66-72, 2009.

DE GROOT, N.S.; VENTURA, S.: Effect of temperature on protein quality in bacterial inclusion bodies. FEBS Lett, v. 580, n. 27, p. 6471-6476, 2006. 
EDELING, M.A.; DIAMOND, M.S.; FREMONT, D.H.: Structural basis of Flavivirus NS1 assembly and antibody recognition. Proc Natl Acad Sci U S A 111, p. 42854290, 2014.

FOGUEL, D.; ROBINSON, C.R.; DE SOUSA, P.C.; SILVA, J.L.; ROBINSON, A.S.: Hydrostatic pressure rescues native protein from aggregates. Biotechnol Bioeng 63:552-558, 1999.

GATTI-LAFRANCONI, P.; NATALELLO, A.; AMI, D.; DOGLIA, S.M.; LOTTI, M.: Concepts and tools to exploit the potential of bacterial inclusion bodies in protein science and biotechnology. FEBS J 278:2408-2418, 2011.

GUZMAN, M.G.; HALSTEAD, S.B.; ARTSOB, H.; BUCHY, P.; FARRAR, J.; GUBLER, D.J.; HANSPERGER, E.; KROEGER, A.; MARGOLIS, H.S.; MARTÍNEZ, E.; NATHAN, M.B.; PELEGRINO, J.L.; SIMMONS, C.; YORKSAN, S.; PEELING, R.W.:Dengue: a continuing global threat. Nat Rev Microbiol 8:S716.

HUANG. J.L.; HUANG, J.H.; SHYU R.H.; TENG, C.W.: High-level expression of recombinant dengue viral NS-1 protein and its potential use as a diagnostic antigen. J Med Virol 65:553-560, 2001.

KUNO, G.; CHANG, G.J.: Full-length sequencing and genomic characterization of Bagaza, Kedougou, and Zika viruses. Arch Virol, v. 152, n. 4, p. 687-696, 2007.

LAEMMLI, U.K.: Cleavage of structural proteins during the assembly of the head of bacteriophage T4. Nature, v. 227, p. 680-685, 1970.

LANCIOTTI, R.S.; KOSOY, O.L.; LAVEN, J.J.; VELEZ, J.O.; LAMBERT, A.J.; JOHNSON, A.J.; STANFIELD, S.M.; DUFFY, M.R.: Genetic and serologic properties of Zika virus associated with an epidemic, Yap State, Micronesia, 2007. Emerg Infect Dis, v. 14, n. 8, p. 1232-1239, 2008.

MALAVASI, N.V.; FOGUEL, D.; BONAFE, C.F.S.; BRAGA, C.A.C.A.; CHURRACHAMBI, R.M.; VIEIRA, J.M.; MORGANTI, L.: Protein refolding at high pressure: Optimization using eGFP as a model. Process Biochemistry, v. 46, n. 2, p. 512518, 2011.

MALAVASI, N.V.; CORDEIRO, Y.; RODRIGUES, D.; CHURRA-CHAMBI, R.M.; LEMKE, L.S.; MORGANTI, L.: The effect of temperature on protein refolding at high pressure: Enhanced green fluorescent protein as a model. Process Biochemistry 49:54-60, 2014.

MURRAY, N.E.; QUAM, M.B.; WILDER-SMITH, A.: Epidemiology of dengue: past, present and future prospects. Clin Epidemiol 5:299-309. 2013.

PATRA, A.K.; MUKHOPADHYAY, R.; MUKHIJA, R.; KRISHNAN, A.; GARG, L.C.; PANDA, A.K.: Optimization of inclusion body solubilization and renaturation of recombinant human growth hormone from Escherichia coli. Protein Expr Purif, v. 18, n. 2, p. 182-192, 2000. 
RANDOLPH, T.W.; SEEFELDT, M.; CARPENTER, J.F.: High hydrostatic pressure as a tool to study protein aggregation and amyloidosis. Biochim Biophys Acta 1595:224-234, 2002.

RATHORE, A.S.; BADE P.; JOSHI,V.; PATHAK, M.; PATTANAYEK, S.K. et al.: Refolding of biotech therapeutic proteins expressed in bacteria: review. Journal of Chemical Technology and Biotechnology, v. 88, n. 10, p. 1794-1806, 2013.

SCHEYHING, C.H.; MEERSMAN, F.; EHRMANN, M.A.; HEREMANS, K.; VOGEL, R.F.: Temperature-pressure stability of green fluorescent protein: a Fourier transform infrared spectroscopy study. Biopolymers 65:244-253, 2002.

SEN, P.; AHMAD, B.; KHAN, R.H.: Formation of a molten globule like state in bovine serum albumin at alkaline $\mathrm{pH}$. European Biophysics Journal with Biophysics Letters 37:1303-1308, 2008.

SILVA, J.L.; WEBER, G.: Pressure stability of proteins. Annu Rev Phys Chem, v. 44, n. 1, p. 89-113, 1993.

SILVA, J.L.; FOGUEL, D.: Royer C.A.: Pressure provides new insights into protein folding, dynamics and structure. Trends Biochem Sci, v. 26, n. 10, p. 612-618, 2001.

SINGH, A.; UPADHYAY, V.; UPADHYAY, A.K.; SINGH, S.M.; PANDA, A.K.:

Protein recovery from inclusion bodies of Escherichia coli using mild solubilization process. Microb Cell Fact, v. 14, n. 1, p. 41, 2015.

SINGH, S.M.; PANDA, A.K.: Solubilization and refolding of bacterial inclusion body proteins. J Biosci Bioeng, v. 99, n. 4, p. 303-310, 2005.

SING, S.M.; UPADHYAY, A.K.; PANDA, A.K.: Solubilization at high pH results in improved recovery of proteins from inclusion bodies of $\mathrm{E}$. coli. Journal of Chemical Technology and Biotechnology 83:1126-1134, 2008.

SONG, H.; QI, J.; HAYWOOD, J.; SHI, Y. GAO, G.F.: Zika virus NS1 structure reveals diversity of electrostatic surfaces among flaviviruses. Nat Struct Mol Biol, v. 23, p. $456-458,2016$.

ST JOHN, R.J.; CARPENTER, J.F.; RANDOLPH, T.W.: High pressure fosters protein refolding from aggregates at high concentrations. Proc Natl Acad Sci U S A 96:13029-13033, 1999.

ST JOHN, R.J.; CARPENTER, J.F.; BALNY, C.; RANDOLPH, T.W.: High pressure refolding of recombinant human growth hormone from insoluble aggregates.

Structural transformations, kinetic barriers, and energetics. J Biol Chem 276:46856-46863, 2001.

ST JOHN, R.J.; CARPENTER, J.F.; RANDOLPH, T.W.: High-pressure refolding of disulfide-cross-linked lysozyme aggregates: thermodynamics and optimization.

Biotechnol Prog, v. 18, n. 3, p. 565-571, 2002. 
SUTHAR, M.S.; DIAMOND, M.S.; GALE, M. JR.: West Nile virus infection and immunity. Nat Rev Microbiol, v. 11, n. 2, p. 115-128, 2013.

VERA, A.; GONZALEZ-MONTALBAN, N.; ARIS, A.; VILLAVERDE, A.: The conformational quality of insoluble recombinant proteins is enhanced at low growth temperatures. Biotechnol Bioeng 96:1101-1106, 2007.

VINCENTELLI, R.; CANAAN, S.; CAMPANACCI, V.; VALENCIA, C.; MAURIN, D.; FRASSINETTI, F.; SCAPPUCINI-CALVO, L.; BOURNE, Y.; CAMBILLAU, C.; BIGNON, C.: High-throughput automated refolding screening of inclusion bodies. Protein Sci, v. 13, n. 10, p. 2782-2792, 2004.

WALLIS, T.P,; HUANG, C.Y.; NIMKAR, S.B.; YOUNG, P.R.; GORMAN, J.J.: Determination of the disulfide bond arrangement of dengue virus NS1 protein. J Biol Chem, v. 279, n. 20, p. 20729-20741, 2004.

WHITEHEAD, S.S.; BLANEY, J.E.; DURBIN, A.P.; MURPHY, B.R.: Prospects for a dengue virus vaccine. Nat Rev Microbiol 5:518-528, 2007.

YASOTHAI, R.; GIRIPRASAD, R.: Acid/alkaline solubilization method of processing protein International Journal of Science Environment 4:96-100, 2015.

YOUNG, P.R.; HILDITCH, P.A.; BLETCHLY, C.; HALLORAN, W.: An antigen capture enzyme-linked immunosorbent assay reveals high levels of the dengue virus protein NS1 in the sera of infected patients. J Clin Microbiol, v. 38, n. 3, p. 1053-1057, 2000. 